\title{
The Confidentiality of HIV-Related Information: Responding to the Resurgence of Aggressive Public Health Interventions in the AIDS Epidemic
}

\author{
Roger Doughty
}

Table of Contents

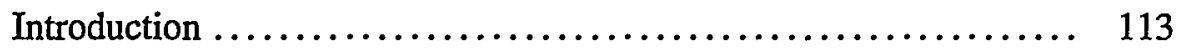

I. Background: Confidentiality, Public Health, and the AIDS

Epidemic .................................... 116

A. The Idea of Confidentiality ..................... 116

B. Public Health Strategies and Communicable Diseases ..... 118

C. The Difference with AIDS: Discrimination and the Importance of Confidentiality ................... 122

II. New Threats to the Confidentiality of HIV-Related

Information ................................... 128

A. Strains on the Consensus ....................... 128

B. Implications for Confidentiality .................. 133

C. The Redefinition of AIDS ..................... 136

D. The Need to Assess Confidentiality Protections for HIVRelated Information ........................... 140

III. Present Protections for Confidentiality of HIV-Related Information ................................. 140

A. HIV-Specific Statutory Protection in California ......... 141

B. General Statutory Protection for Confidentiality of Medical Information ............................... 144

C. The Right to Privacy: Constitutional and Common Law Doctrines ....................................... 148

1. Federal Right to Privacy ..................... 148

2. The Right to Privacy in California .............. 154

3. Common Law Privacy Causes of Action........... 157

4. Summary ............................... 160

D. Functioning of the Three Levels of Privacy Protection .... 161

IV. The Resurgence of Aggressive Public Health Strategies and Present Protections for Confidentiality ................. 163

A. Mandatory Name Reporting $\ldots \ldots \ldots \ldots \ldots \ldots \ldots \ldots .163$ 
B. Partner Notification and Contact Tracing ............ 167

1. Potential Hazards of Expanded Partner Notification Programs ................................. 167

2. Present Confidentiality Protections and Partner Notification ................................. 169

3. Partner Notification and Public Health.............. 170

a. Weighing the Evidence................... 170

b. Balancing Confidentiality Concerns and Public Health.............................. 174

C. Impact of the Redefinition of ADS on Confidentiality .... 175

V. Toward Strengthening Confidentiality Protections........... 177

A. Protecting HIV-Related Information................ 177

1. Federal Policy........................... 177

a. Establish a Confidentiality "Floor" for HIV-Related Information ............................ 178

b. Maintain and Enhance Anonymous Testing Options ............................. 178

c. Prohibit Name Reporting of HIV-Positive Persons . 179

d. Ban Nonsurveillance Uses of Surveillance Data ... 179

e. Issue Comprehensive Guidance for Contact Tracing and Partner Notification Programs ............ 180

2. State-Level Policy ............................. 181

B. Protecting CD4 Information $\ldots \ldots \ldots \ldots \ldots \ldots \ldots \ldots \ldots, 181$

1. Enact State Statutory Protections .............. 181

2. Bar Laboratory-Based Reporting of Individually Identifiable Test Results ........................ 182

3. Require Informed Consent for CD4 Testing......... 183

C. Effect of Strengthening Confidentiality Protections on Constitutional Remedies .......................... 183 


\section{The Confidentiality of HIV-Related Information: Responding to the Resurgence of Aggressive Public Health Interventions in the AIDS Epidemic}

\section{Roger Doughty $\dagger$}

During the 1980s, a crucial confluence of opinion among public health officials, key elected officials, and AIDS and gay and lesbian advocates led to the establishment of strong protections to ensure the confldential treatment of AIDS- and HIV-related information. This consensus is now being strained by the emergence of intrusive public health disease control measures and the recent redefinition of the case surveillance definition of AIDS. In this Comment, the author examines these new threats to confidentiality in light of three levels of confidentiality protection that now exist: statutory protection for HIV-speciflc information, statutory protection for medical information, and constitutional and common law privacy rights. The author argues that, given the rapid pace of change in government policies surrounding HIV-related information, legal protections for confidentiality are inadequate to serve the dual function of preserving civil liberties and promoting public health. The author concludes by suggesting several ways of bolstering protections against future potential breaches of confldentiality.

\section{INTRODUCTION}

In the first decade of the human immunodeficiency virus (HIV) epidemic in the United States, ${ }^{1}$ a crucial confluence of opinion among public health officials, key elected officials, and AIDS and gay and lesbian advocates led to the establishment of strong protections to ensure the confiden-

Copyright $\odot 1994$ California Law Review, Inc.

$\dagger$ J.D. Candidate 1994, Boalt Hall School of Law, University of California, Berkeley; M.P.P. 1993, University of Califomia, Berkeley. The author would like to thank Paul A. Di Donato, Director of Public Policy, AIDS Legal Referral Panel, San Francisco; Matthew Coles, Staff Attorney, American Civil Liberties Union of Northern California; and Elizabeth B. Cooper, Gibbons Fellow in Public Interest and Constitutional Law, Crummy, Del Deo, Dolan, Griffinger \& Vecchione, Newark, New Jersey, for their invaluable criticisin, advice, and support.

1. The first cases of opportunistic infections associated with immune system suppression due to HIV infection were reported by the Centers for Disease Control in 1981. For a brief summary of the early history of AIDS, see June E. Osbom, The AIDS Epidemic: Discovery of a New Disease, in AIDS AND THE LAW 17 (Harlon L. Dalton et al. eds., 1987). 
tial treatment of AIDS- and HIV-related information. The unprecedented nature of the epidemic, in which the highest-risk populations were already marginalized and, as a result of the disease, faced with widespread discrimination, led public health officials to downplay aggressive public health strategies and, to a large extent, to join gay and AIDS advocates in emphasizing confidential treatment for all HIV-related information. Confidentiality became a cornerstone of policies designed both to safeguard individual rights and to prevent the further spread of HIV; the two goals were, to a large extent, seen as complementary and mutually reinforcing.

As the second decade of the epidemic progresses, however, the consensus surrounding HIV confidentiality is becoming strained. The protections developed in the early years of the epidemic face potential new threats stemming from the emergence of aggressive and intrusive public health disease control techniques and from the recent redefinition of the case surveillance definition of AIDS. These developments raise new questions about the adequacy of current constitutional, common law, and statutory shields for confidentiality of HIV-related information.

This Comment examines these new threats to confidentiality and the safeguards intended to maintain it. It discusses the link between confidentiality protections and sound public health strategies to combat the epidemic, assesses the sufficiency of the current legal safeguards, and explores possible improvements in these areas.

Although the HIV epidemic has brought the issue of confidentiality of medical information to new prominence and controversy, questions of confidentiality and the potential for conflict between individual rights and the public health are far from new. Part I of the Comment paints the backdrop for the current controversies around confidentiality of HIV-related information $^{2}$ by exploring the concept of confidentiality as a right and as a principle of medical ethics, the historical tension between medical confidentiality and aggressive public health control strategies, and the changes demanded in public health strategies by the advent of the HIV epidemic.

As the epidemic has raced into its second decade, however, the consensus view of confidentiality as a means to promote the ends of both civil liberties and public health has come under severe strain. Growing numbers of people have begun to advocate more aggressive public health control strategies that threaten this consensus. Part II describes the nature of these efforts and the potential hazards they pose to confidentiality and the public health. ${ }^{3}$

2. This Comment uses the phrase "HIV-related information" to refer broadly to any and all information regarding an individual's possible or actual exposure to HIV or manifestation of any HIVrelated conditions (e.g., Kaposi's sarcoma, a previously rare cancer which affects many HIV-infected persons).

3. It is important to note that in some contexts, "aggressive" measures are not only desirable but vital in the fight against HIV. For example, federal prevention education programs have long been justifiably criticized for being ill-focused and inconsistent. Similarly, "aggressive" efforts to help HIV- 
Over the epidemic's first twelve years, a complex web of legal protections for the confidentiality of HIV-related information emerged. Part III explores three distinct but related types of protection: statutes specifically designed to prohibit breaches of confidentiality of HIV-related information; statutory protection for the confidentiality of medical information; and constitutional and common law privacy rights. The three levels of confidentiality protection function as a triple-tiered net in which each level can prevent or "catch" certain breaches of confidentiality.

Part IV analyzes the sufficiency of these three levels of protection in light of the new threats to confidentiality. Such analysis is essential in light of the rapid pace of change in federal and state policies surrounding HIVrelated information. These protections need to serve two basic goals. First, they should be clear and strong enough to deter those coming into contact with HIV-related information from deliberately or negligently disclosing such information. Second, the protections should offer legal recourse to persons whose confidentiality is breached, providing compensation for something that can never truly be replaced, namely, confidentiality.

The Comment concludes that, although the three tiers of confidentiality protection offer relatively powerful insurance against future potential breaches of confidentiality, the resurgence of aggressive public health measures requires that several steps be taken at both the federal and state levels to ensure that confidentiality is maintained in all instances. The Comment then suggests several ways of bolstering those protections.

While the scope of the discussion is national, the Comment pays special attention to California. Not only does California have a very high incidence of HIV disease, but it also has a particularly strong tradition of privacy rights, ${ }^{4}$ and has been at the forefront of legislative activity to protect HIV confidentiality. 5 The state of confidentiality protections in California, then, provides both a case study and a rough gauge for assessing the adequacy of present protections for HIV-related information. Inadequacies in California are likely to be magnified in other jurisdictions that lack this state's comparatively strong protections. Moreover, because policies governing the handling of HIV-related information can be drawn from one state to another, approaches proposed or successfully applied in California can be used elsewhere.

infected people manage their condition therapeutically, economically, and psychologically are essential. In this Comment, the term "aggressive" applies specifically to state-sponsored programs that involve the collection, use, and/or dissemination of personal HIV-related information (e.g., name reporting, partner notification, and contact tracing).

4. The right to privacy is protected explicitly in the California Constitution. CaL. Const. art. I, $\S 1$; see also White v. Davis, 533 P.2d 222, 233 (Cal. 1975); Chico Feminist Women's Health Ctr. v. Scully, 256 Cal. Rptr. 194, 199 (Ct. App. 1989).

5. California enacted the first specific confidentiality protections for HIV-related information. Harold Edgar \& Hazel Sandomire, Medical Privacy Issues in the Age of AIDS: Legislative Options, 16 AM. J.L. \& MED. 155, 158 (1990). 
I

Background: Confmentiality, Public Health, and the AIDS EPIDEMIC

\section{A. The Idea of Confidentiality}

The core idea of confidentiality has a long history within the medical profession, although it has only more recently emerged into the domain of legal rights and interests. The fundamental concept of medical information confidentiality dates back at least as far as the Hippocratic Oath, written in the fourth century B.C. ${ }^{6}$ Its basic command-that medical information about a patient not be disclosed beyond those who need to know for the purposes of the patient's medical care or those whom the patient chooses to inform-is echoed in contemporary medical ethics, ${ }^{7}$ statutory protections, ${ }^{8}$ the common law, ${ }^{9}$ and constitutional law. ${ }^{10}$ The developing sense that medical information is, at least to a significant extent, properly within the private control of a patient is closely linked to the emergence of the concept of "privacy" as a morally valued, politically accepted, and legally protected area of constitutional rights. ${ }^{11}$

"Confidentiality" as used in this Comment has two basic aspects: access to and control of information. The question of access is, at its most simple, who is permitted to obtain certain information. In the HIV context, this question might take the form of, should a patient's employer (or insurer, or landlord, or treating hospital, etc.) be allowed to access information contained in the files of a patient's physician (or other keeper of records of HIV-related information)? An important variant of the question, which pertains to the public sector is, should a state be allowed to compile a registry of people with HIV infection (or related medical condition), and if so, what private or public parties can obtain information from the registry?

6. "Whatsoever I shall see or hear in the course of my profession ... if it be what should not be published abroad, I will not disclose, holding such things to be holy secrets." Hippocratic Oath, quoted in Richard Belitsky \& Robert A. Solomon, Doctors and Patients: Responsibilities in a Confidential Relationship, in AIDS AND THE LAW, supra note 1, at 201.

7. The American Medical Association's Principles of Medical Ethics state:

A physician may not reveal the confidence entrusted to him in the course of mcdical attendance, or the deficiencies he may observe in the character of patients, unless he is required to do so by law or unless it becomes necessary in order to protect the welfare of the individual or of the community.

American Medical Ass'w, Princtiles of Medical Ethics $\$ 9$ (1957), quoted in Ann H. Brition, Rights to Privacy in Medical Records, J. LEGAL MED., July-Aug. 1975, at 30, 30.

8. See, e.g., Cal. Civ. Code $\S \S 56.10-37$ (West 1982 \& Supp. 1993); see also Allan M. Brandt, No Magic Bullet: A Soclal History of Venereal Disease in the United States Since 1880 , at 17 (1985) (discussing the widespread codification of patient-physician confidentiality in the Umited States in the mineteenth century).

9. See infra notes $224-39$ and accompanying text.

10. See infra notes $169-203$ and accompanying text.

11. The modern doctrine of privacy is often traced to the famous law review article by Warren and Brandeis. See Samuel D. Warren \& Louis D. Brandeis, The Right to Privacy, 4 Harv. L. Rev. 193 (1890). 
The second aspect of confidentiality is control: who determines who or what has access to information in any given circumstance? The power to decide what persons, and what public or private entities, have access to information could belong to the HIV-infected individual, or it could he in the hands of the state, an einployer, a private health organization, or the provider of inedical services. The greater the affected individual's control, the stronger the guarantee of confidentiality because the individual herself determines who learns this information.

It is generally acknowledged that the patient or client has a profound interest in determining who has access to and control of inedical information about himself. ${ }^{12}$ This interest translates into a certain measure of control over who or what has information access. For exaniple, the patient's physician generally has no authority to disclose information about the patient absent the patient's specific authorization. ${ }^{13}$ Similarly, the state, if it collects any individually identifiable inedical information under statutory authority, generally cannot distribute that information beyond places or persons specifically authorized in the relevant statute. ${ }^{14}$

Another dimension appears, however, when the information involved has public health imphications beyond the individual patient. In such circumstances, the weight given confidentiality is counterbalanced by the potential harm to others. Communicable diseases are the classic example: disclosure of the index patient's status may be useful in stemming the further spread of the disease. ${ }^{15}$ The privacy of medical information doctrine, in other words, can collide with public health notions, and specifically with strategies devised over several decades to combat commumicable diseases. Because HIV/AIDS has obvious public health dimensions, it is necessary to scrutinize public health strategies and law to understand the context of the debate over confidentiality of HIV-related information.

12. See Edgar \& Sandomire, supra note 5, at 160 .

13. See, e.g., CAL. Civ. Code $\$ 56.10$ (West 1982 \& Supp. 1993). An important exception to this rule requires physicians in many states to report cases of particular diseases, including the patient's name, to state health authorities. See, e.g., 17 CAL. CoDE REGs. tit. 17, $\$ 2500$ (Barclays 1992) (listing requirements for reporting of specified diseases within mandated timeframes to state authorities).

14. See, e.g., CAL. CIv. CODE $\$ 56.10(c)(7)$ (West 1982) (permitting disclosure of medical information to "public agencies" and requiring that "no information so disclosed shall be further disclosed by the recipient").

15. For example, the act of quarantining an individual who has a highly contagious disease effectively constitutes a disclosure that the individual has a very serious medical condition (if not the precise condition). The quarantine, however, may prevent spread of the disease by physically isolating the infected person from the rest of the population. As later discussed, this logic may be inapplicable in the case of AIDS, because while HIV is communicable (i.e., the virus can be transmitted from one person to another), it is not contagious like tuberculosis or scarlet fever (which can be transmitted through casual contact). See Helena Brett-Smith \& Gerald H. Friedland, Transmission and Treatment, in AIDS LAW TODAY 18, 29 (Scott Burris et al. eds., 1993) (discussing the noncontagious nature of HIV). Moreover, the exercise of aggressive public health ineasures may actually cause people to avoid the health care system entirely. See infra notes 59-62 and accoinpanying text. 


\section{B. Public Health Strategies and Communicable Diseases}

Since the first cases of AIDS were reported in 1981, the epidemic has posed an unprecedented challenge to public lealth officials, gay, AIDS, and civil liberties advocates, policymakers, and the public at large. Because the disease is caused by a communicable viral agent-the human immunodeficiency virus-a focus of public health policy in the United States has been to prevent the further spread of that agent. One component of prevention is risk-reduction education, both of the population at large and of targeted groups with a disproportionate incidence of HIV infection, including gay men, injection drug users (IDUs), and people of color. ${ }^{16} \mathrm{~A}$ second component of prevention includes more or less aggressive government interventions to identify HIV-positive persons and to reduce the chances of those identified transmitting the virus through sexual contact or needlesharing. ${ }^{17}$ Because aggressive public health ineasures all involve the disclosure and dissemination of highly sensitive medical information-individuals' HIV status-they exist in constant tension with the prevailing concept of confidentiality. Sucli measures have been sharply controversial since the beginning of the AIDS epidemic.

The modern arsenal of public health tools used to combat the spread of communicable diseases developed largely within the past 100 years. The most important of these tools involved identifying individuals infected with an infectious agent, tracking diseases through extensive surveillance and data collection, isolating and quarantining infected individuals that pose immediate hazard of contagion to others, and discovering and notifying possibly exposed persons to seek diagnosis and treatment.

16. See William L. Roper, Current Approaches to Prevention of HIV Infections, 106 PuB. HeALTH REP. 111 (1991) (discussing federally funded HIV prevention education campaigns). Commentators have severely criticized government efforts to target prevention education at high-risk populationsespecially gay and bisexual men and both gay and heterosexual people of color-for inadequately addressing the need for education in those communities. See, e.g., HeLEN ScHIETINGER, AIDS ACtion Counci, Good Intentions: A Report on Federal hiv Prevention Proorams (1991) (criticizing prevention programs for serious inadequacies in targeting gay/bisexual men, people of color, and women); Mark Barnes, Toward Ghastly Death: The Censorship of AIDS Education, 89 CoLum. L. REv. 698 (1989) (reviewing books by Ronald Bayer and Simon Watney that discuss the general failure of AIDS education programs due to politically motivated censorship); Chris Bull, The Silence of the Labs, AdvocaTE, Jan. 12, 1993, at 50, 50 (discussing the failure of the federal Centers for Disease Control to address the issue of risk-reduction education for gay men). Federal censorship of AIDS education materials by prohibiting "offensive" language or depictions became the subject of a protracted suit brought by AIDS service and advocacy organizations. A federal district court struck down the regulations as unconstitutionally vague. See Gay Men's Health Crisis v. Sullivan, 792 F. Supp. 278 (S.D.N.Y. 1992).

17. See, e.g., Technical Guidance on HIV Counseling, 42 MORBLDTY \& MORTALITY WKLY. RBP. 11,11-15 (1993) (describing federally funded counseling, testing, and other intervention programs). The principal sources of HIV infection are through the sharing of contaminated necdles used for injection drugs, sexual transmission, and (prior to development of effective screening of blood) blood products and transfusions. See Richard Green, The Transmission of AIDS, in AIDS AND THE LAW, supra note 1, at 28, 31-36. 
Quarantine and isolation measures, used to prevent physically the possibility of contagion or infection from one person to another, constitute the most aggressive mechanisms in the public health arsenal. ${ }^{18}$ With the advent of vaccines for smallpox and other contagious diseases, mandatory vaccination programs becane a critical weapon in the fight agamst communicable disease. ${ }^{19}$ In the 1930s, public health officials such as Dr. Thomas Parran in New York City pioneered the use of contact tracing and partner notification to stem the spread of venereal diseases. ${ }^{20}$ Although labor-intensive and resource-dependent, these methods becanie widely accepted elements of public health strategies against sexually transmitted diseases (STDs). ${ }^{21}$ The thrust of these programs was to learn the nanies of a venereal disease carrier's sexual partner or partners and to alert those persons to their possible exposure to venereal disease. ${ }^{22}$ The partner(s) would then be tested for infection and treated, thus interrupting the chain of transmission. A final component of this approach was mandatory nane reporting, through which disease carriers' nanies are reported by physicians to public health agen-

18. See Larry Gostin, Traditional Public Health Strategies, in AIDS AND THE LAw, supra note 1, at 47,59-62. Such drastic measures have generally been reserved for use in cases of highly contagious diseases such as tuberculosis, plague, and scarlet fever. See Larry Gostin, Traditional Public Health Strategies, in AIDS LAw TODAY, supra note 15, at 59, 62 (listing cases). However, courts occasionally upheld quarantine even when therc was no danger of contagion. Id. at 63; see also In re Halko, $54 \mathrm{Cal}$. Rptr. 661 (Ct. App. 1966) (upholding enforced isolation of a tuberculosis patient).

19. All but two states have mandatory vaccination programs for public school students. The courts have consistently found such programs constitutional. See LuAnn A. Polito, Containing the AIDS Virus, 37 CLEv. ST. L. Rev. 369, 384 \& n.119 (1989).

20. For a discussion on the early developinent of contact tracing efforts, see BRANDT, supra note 8, at 150-60. The terms "partner notification" and "contact tracing" are employed with great variation in public health. Although the terms are sometimes used interchangeably, they will be distinguished in this Comment. While partner notification and contact tracing share several basic features, they differ in important ways. Most significantly, partner notification is generally focused on the index patient's primary sexual (or, in the ease of HIV, needle-sharing) partner and is carried out by either the index patient, a medical care provider, or the state. Contact tracing, by contrast, is desigued to track as many of an index patient's partners as possible through state-sponsored investigation and contact. In a sense, a contact tracing program consists of many separable partner notifications. In this Comment, "partner notification" refers to programs targeted at a primary sexual (or needle-sharing) partner, and "contact tracing" refers to more broadly aimed systematic programs of partner identification and contact. For a general discussion of partner notification and contact tracing, see James T. Dimas \& Jordan $\mathrm{H}$. Richland, Partner Notification and HIV Infection: Misconceptions and Recommendations, 4 AIDS \& PUB. PoL'y J. 206 (1989).

21. Ronald Bayer \& Kathleen E. Toomey, HIV Prevention and the Two Faces of Partner Notification, 82 AM. J. PuB. HeAlth 1158, 1159 (1992); see also Brandt, supra note 8, at 150-60.

22. See BRANDT, supra note 8 , at $150-54$. 
cies, ${ }^{23}$ which would compile registries for use in contact tracing and in tracking the course and virulence of the disease. ${ }^{24}$

Key aspects of all these aggressive public health strategies include the disclosure, dissemination, and use of information about individuals infected by disease or an infectious agent. Name reporting of people with diseases entails compiling and maintaining an official hist of infected persons. Partner notification and contact tracing programs depend on a persons' divulgence of names of potentially infected individuals and entail state efforts to find those named. Quarantine and isolation, by definition, single out affected people-often in a very pnblic way-for severe and overt treatment. In each of these strategies, it is essential for the identities of infected and potentially infected persons to be known at least to the state and, in some cases, more widely. With such dissemination of information about an individual's actual or potential medical condition comes the threat that the mdividual may experience consequences ranging from embarrassment to loss of livelihood. ${ }^{25}$

Over the years, many of these public health measures have been challenged as invasions of private rights and interests. The courts have generally rejected such arguments, holding that protection of the public health through implementation of measures to control infectious disease fell clearly within the police powers of the state and that the state therefore had wide latitude to take what measures it believed to be required. ${ }^{26}$ In a still leading case, Jacobson v. Massachusetts, ${ }^{27}$ the U.S. Supreme Court upheld a mandatory state vaccination program, observing that "[a]lthough this court has refrained from any attempt to define the himits of [the police

23. Lamy Gostin, Traditional Public Health Strategies, in Ams AND tHE LAw, supra note 1, at 58 ("Every state requires that specified 'listed' or 'notifiable' diseases be reported to its public health department."); see also William J. Curran et al., AIDS: Legal and Policy Implications of the Application of Traditional Disease Control Measures, 15 LAW MED. \& HEALTH CARE 27, 27 (1987) ("Mandatory disease-reporting has traditionally provided the means of locating the source of infection, tracing epidemics, and identifying infectious individuals who might be subject to quarantine or isolation.").

24. This array of public health strategies to combat communicable diseases, including name reporting, contact tracing, and partner notification, is often labelled "traditional public health strategy." See, e.g., Larry Gostin, Traditional Public Health Strategies, in AIDS AND tHE LAw, supra note 1. This Comment does not use this term because "traditional" suggests that there exists a particular, welldefined model that should be used against any communicable or infectious disease. The HIV epidemic, however, differs in important ways from other epidemies, see infra Part I.C. and therefore docs not necessarily fit any "traditional" model. Rather, because all of the public health measures consciously involve an active role for the state in identifying, contacting, and treating possibly infected persons, this Comment will use the terms "aggressive" and "intrusive" to describe these public health strategies.

25. See generally William H. McNenl, Plagues and Peoples (1976) (recounting hysteria surrounding epidemies and actions taken by the healthy against the sick); David I. Schulman, AIDS Workplace Law \& Policy, 9 ST. Lours U. PuB. L. REv. 543, 547 (1990) (discussing discrimination against the sick generally as the background for a discussion of discrimination against people infected with HIV).

26. See, e.g., Barsky v. Board of Regents, 347 U.S. 442, 449 (1954); Hawker v. New York, 170 U.S. 189, 191-95 (1898); Railroad Co. v. Husen, 95 U.S. 465, 470-71 (1877).

27. 197 U.S. 11 (1905). 
power], yet it has distinctly recognized the authority of a State to enact quarantine laws and 'health laws of every description." "28 The Jacobson court underscored that not only does the state have the power to undertake such measures, but that it has the duty to protect the interests of the many (the "healthy") against the interests of the few (the "sick"). ${ }^{29}$ Name reporting is generally considered to lie comfortably within the state's powers, ${ }^{30}$ and courts have on numerous occasions upheld even the inost extreine strategies, quarantine and isolation, ${ }^{31}$ as well as inandatory vaccination programs $^{32}$ and involuntary testing of suspected disease carriers. ${ }^{33}$

While many early decisions granted public health officials almost unlimited discretion in designing public health policy, ${ }^{34}$ some courts began to insist on at least some sound inedical basis for such decisions. Specifically, courts developed a standard which requires that the state's public health action be for a "legitimate" purpose and that the ineans it employs be "reasonably related" to the achievement of that purpose. ${ }^{35}$ Courts have barred enforceinent of measures found to be unreasonable and unwarranted by immediate public health needs. ${ }^{36}$ For exainple, a 1900 federal court decision in California ended San Francisco's quarantine of more than 10,000 Chinese during a bubonic plague panic because the city was unable to provide a factual basis for singling out Chinese. ${ }^{37}$ Nonetheless,

28. Id. at 25.

29. Id. at 29.

30. See Whalen v. Roe, 429 U.S. 589, 606 (1977) (Brennan, J., concurring) ("[L]imited reporting requirements in the medical field are familiar, and are not generally regarded as an invasion of privacy." (citation omitted)). Reporting requirements for infectious diseases have only rarely been subjected to legal challenge. Catherine J. Damme, Controlling Genetic Disease Through Law, 15 U.C. Davis L. REv. 801, 807 (1982).

31. See, e.g., Ex parte Martin, 188 P.2d 287 (Cal. 1948) (recognizing state's power to use quarantine measures to prevent spread of disease); In re Halko, 54 Cal. Rptr. 661 (Ct. App. 1966) (upholding confinement of tuberculosis patient to lospital for six months); Crayton v. Larabee, 116 N.E. 355 (N.Y. 1917) (upholding law prohibiting all contact with houses whose occupants had scarlet fever or smallpox). Each of these cases arose in the context of a campaign against a highly contagious disease. See supra note 18.

32. See, e.g., Jacobson, 197 U.S. at 39 (upholding state statute requiring vaccination against smallpox of all residents over 21 years of age).

33. See, e.g., Reynolds v. McNichols, 488 F.2d 1378 (10th Cir. 1973) (upholding local government's power to detain and, without permission of the detainee, test and treat a person reasonably suspected of carrying a venereal disease); Ex parte Fowler, 184 P.2d 814 (Okla. Crim. App. 1947) (same).

34. For a concise review of public health cases in which courts granted wide discretion to public officials, see Larry Gostin, Traditional Public Health Strategies, in AmS AND THE LAw, supra note 1, at $60-63$.

35. See Scott Burris, Fear Itself: AIDS, Herpes and Public Health Decisions, 3 Yale L. \& PoL'y Rev. 479, 481 (1985). Burris discusses the history of U.S. court cases througl which courts gradually introduced requirements that the state show sufficient facts to justify its public health actions as "reasonably related" to the state's public health objective. Id. at 486-90.

36. See Deborah Jones Merritt, The Constitutional Balance Between Health and Liberty, in AIDS: An Epidemic of Ethical Puzzles 56, 58-59 (The Hastings Center ed., 1991) (reviewing cases in whicl courts overturned public health measures as unwarranted by public health necds).

37. Jew Ho v. Williamson, 103 F. 10, 23-24 (C.C.N.D. Cal. 1900). 
the standard is far from stringent: the state need only have a legitimate interest and prove that a rational relationship exists between that interest and the means the state employs. Given both the courts' recognition of the state's crucial public health role ${ }^{38}$ and judicial deference to the executive and legislative branches im this specialized area, ${ }^{39}$ the state's discretionary authority is wide. The state will almost certainly meet the "legitimate purpose" requirement when it takes action to protect or promote public health, provided that the "public health" justification is not mere window dressing for an impermissible purpose. The rational relationship requirement is potentially more difficult to meet, at least in the case of HIV, where the empirical data tend to be ambiguous. ${ }^{40}$ Nevertheless, a court is likely to strike down a public health measure only if it stems from an illegitimate motivation or is demonstrably irrational and unrelated to its public health rationales.

\section{The Difference with AIDS: Discrimination and the Importance of Confidentiality}

Throughout the AIDS epidemic, many public health figures, politicians, and commentators have called for the application of aggressive and intrusive measures to fight the spread of AIDS. These voices have called for mass screening programs, ${ }^{41}$ quarantine of people with $\mathrm{AIDS},{ }^{42}$ and rigorous partner notification programs. ${ }^{43}$ Although some states have pursued a number of these strategies, ${ }^{44}$ most have followed a notably different approach.

A less intrusive strategy emerged for fighting the spread of HIV because the disease itself is radically different from previous epidemics. At the heart of the difference lie the greater stigma attached to the disease and discrimination directed at people with HIV, which have led to an emphasis on protecting the confidentiality of HIV-related information, especially the

38. See supra text accompanying notes 26-29.

39. See Mark Barnes, Confidentiality, in AIDS LeGal Guide 4-1, 4-2 (Abby R. Rubenfeld ed., 2d ed. 1987); Larry Gostin, Traditional Public Health Strategies, in AIDS AND THE LAw, supra note 15, at 59-60 ("Traditionally, judges have deferred to the decisions of legislators and health officials, upholding health measures as long as they were reasonably necessary and not unreasonably oppressive.").

40. See infra notes 62,74 and accompanying text.

41. See Ronald Bayer, Private Acts, Soctal Consequences: Aids and the Politics of Public HeAlth 142-46 (1989) (reviewing debates over mass screening proposals to combat the spread of HIV); Gary L. Bauer, AIDS Testing, AIDS \& PuB. POL'Y J. 1 (1988) (calling for mandatory screening of the entire population); Richard F. Duncan, Public Policy and the AIDS Epidemic, 2 J. ConTEMP. HeAlth L. \& Pol'y 169, 170 (1986) (same).

42. BAYER, supra note 41, at 169 (citing examples of calls for isolation and quarantine of HIVinfected persons).

43. See id. at 123-34 (discussing the development of contact tracing programs in the HIV epidemic); Franklyn N. Judson \& Thomas M. Vernon, Jr., The Impact of AlDS on State and Local Health Departments: Issues and a Few Answers, 78 AM. J. PUB. HeALTH 387, 388 (1988) (calling for implementation of widespread aggressive contact tracing and partner notification programs).

44. See infra notes $67-68$ and accompanying text. 
names of affected individuals. Because aggressive public health strategies depended on the identification and vigorous pursuit of affected persons, they directly conflicted with the confidentiality concerns of those persons.

While confldentiality figured importantly in the development of venereal disease contact tracing programs and other public liealth strategies, ${ }^{45}$ it assumed greater prominence in the case of AIDS. This emphasis was due to several factors. First, those most affected by the epidemic were disproportionately members of socially stigmatized groups with a well-developed mistrust of government intentions toward them. The epidemic initially was recognized among gay men, and gay men have continued to constitute a majority of U.S. AIDS cases. ${ }^{46}$ Long accustomed to officially sanctioned and practiced discrimination on the basis of their sexual orientation, gay men and lesbians were profoundly suspicious of the government's intentions and programs in combatting AIDS. ${ }^{47}$ The gay political movement, whose fundamental tenet lay in the right to privacy from government intrusion, perceived AIDS as a tremendous threat to gains it had won and a huge obstacle to further liberation. Accordingly, gay and AIDS advocates fiercely contested the implementation of many of the aggressive public health measures used against other infectious diseases. ${ }^{48}$ Nor has mistrust of government intentions been limited to the gay community. Other groups disproportionately affected by AIDS have, for varying reasons, been wary of government designs. Injection drug users' risk-defining behavior is itself criminal, automatically making DUS mistrustful of government. ${ }^{49}$ People of color-especially inany African Americans ${ }^{50}$ - have also been marginal-

45. See BrandT, supra note 8 , at 150-60.

46. Update: Acquired Immunodeficiency Syndrome-United States, 1992, 42 MORBIDITY \& MORTALITY WKIY. REP. 547, 547-48 (1993) ("male homosexual/bisexual contact" accounting for 50.8\% of cases reported in 1992); Projections of the Number of Persons Diagnosed with AIDS and the Number of Immunosuppressed HIV-Infected Persons-United States, I992-1994, MORBIDITY \& MORTALITY WKLY. REP., Dec. 25, 1992, at 1, 9 (estimating U.S. AIDS cases categorized by mode of transmission, and projecting that gay and bisexual men will account for 258,000 to 328,000 of AIDS cases by the end of 1994 , compared to projections of 137,500 to 183,500 for all other groups combined).

47. See generally BAYER, supra note 41. Most gay or lesbian sexual relations (homosexual sodomy) remain criminalized in almost half the states. See Bowers v. Hardwick, 478 U.S. 186, 193-94 (1986) (discussing the fact that until 1961 all 50 states criminalized sodomy, and that by 1986, 24 states still had sodomy laws). The Supreme Court in 1986 found such laws constitutional. Id. at 196. The effect of antisodomy laws is, of course, to criminalize the same sexual activities that, particularly in the case of gay men, can lead to transmission of HIV. To be a gay man with AIDS in a state that criminalizes sodomy is, effectively, to admit to having broken the criminal law. In addition, gay men and lesbians have long been subject to widespread discrimination in employment, housing, public accommodations, custody decisions, and many other areas. See infra notes 53-54 and accompanying text.

48. See, e.g., BAYER, supra note 41, at 101-36 (discussing gay leaders' opposition to proposals for mandatory-and, at one time, voluntary - testing, name reporting, and contact notification).

49. See Larry Gostin, Drug Dependency and HIV, in AIDS LAw TODAY, supra note 15, at 150, 156 ("Drug users are generally criminalized, marginalized, and unorgamized, making them hard to reach with a public health message.").

50. Many in the African American community harbor deep-seated mistrust of public health programs due to historical mistreatment by the health care system, lack of access, incompatibility 
ized historically, less linked to the formal health care system, and trained by long experience to be leery of government intentions. ${ }^{51}$ For many women, who comprise an increasing percentage of HIV-infected persons, mistrust has been increased by fears that their HIV status could jeopardize their custody of children. ${ }^{52}$ Public health officials had to overcome these deeprooted mistrusts to make AIDS strategies succeed.

Second, as AIDS spread, it spawned widespread discrimination against people with AIDS, people thought to have AIDS or HIV infection, gays and lesbians, and even those who cared for or associated with people with AIDS. ${ }^{53}$ The widespread fear and even hysteria which surrounded the epidemic from its beginning fueled discrimination. ${ }^{54}$ The stark reality that a person with AIDS or HIV could lose his or her job, housing, health care, friends, family, and other necessities of life reinforced fears about the disclosure of information relating to people's HIV status. While HIV-positive persons' particular fears varied from individual to individual-for example, a person einployed in a conservative corporation might most fear loss of employinent, while a heterosexual woman might most fear violence from

between prevailing health care methods and community norms, institutionalized racism, and other factors. See Woodrow Jones, Jr. \& Mitchell F. Rice, Black Health Care: An Overview, in Hralth Carg Issues IN BLACK AMERICA 3-9 (Woodrow Jones, Jr. \& Mitchell F. Rice eds., 1987). These concerns have appeared strongly in the context of the HIV epidemic. See National Comm'N ON AIDS, ThE Challenge of HIV/AIDS in Communities of Color $33-37$ (1992). So powerful has this mistrust of government intentions been that some in the African-American community have fcared that AlDS is a governmentally engineered genocidal assault on the community. For a discussion, see Harlon L. Dalton, AIDS in Blackface, DAEDALus, Summer 1989, at 205, 220-22. Frequent speculation that HIV originated in Africa has increased this mistrust and concern. NATIONAL CoMm'N ON AIDS, supra at 36.

51. Latinos/as, Asian and Pacific Islander Americans, and Native Americans all experience significant barriers to accessing health care services in general and HIV services in particular. While the specific issues facing each group are unique, a common thread is that the combination of a lack of strong links to the health system and the system's unresponsiveness to unique cultural, linguistic, and nicdical needs of these communities seriously impedes AIDS education and services. See National Comm'N oN AIDS, supra note 50, at 38-63.

52. Letter from Leslie R. Wolfe, Executive Director, Center for Women Policy Studies, to James A. Mason, Assistant Secretary for Health, Dept. of Health and Human Services 7 (May 28, 1992) (on file with author).

53. See American Civil Liberties Union, Epidemic of FEAr (1990) (containing extensive documentation and discussion of AIDS and HIV-related discrimination); REPORT OF THE PRESIDENTIAL COMmission on tHe HUMAN IMMUNODEFICIENCY VIRUs EPIDEMIC 119-26 (1988) [hereinafter REPORT OF the PREsidential Commission] (recognizing that "HIV-related discrimination is impairing this nation's ability to limit the spread of the epidemic"); Mary C. Dunlap, AIDS and Discrimination in the United States: Reflections on the Nature of Prejudice in a Virus, 34 VחL. L. REv. 909 (1989). People infected with HIV have faced discrimination in numerous settings. See, e.g., Chalk v. United States Dist. Court, 840 F.2d 701 (9th Cir. 1988) (employment discrimination in a school setting); Doe v. Belleville Pub. Sch. Dist., 672 F. Supp. 342 (S.D. Ill. 1987) (education discrimination).

54. See South Fla. Blood Serv., Inc. v. Rasmussen, 467 So. 2d 798, 802 (Fla. Dist. Ct. App. 1985) (calling AIDS "the modern day equivalent of leprosy" with respcct to the discrimination visited on people with HIV infection); DENNIS ALTMAN, AIDS IN THE MIND OF AMERICA 58-78 (1986) (reviewing numerous manifestations of AIDS-inspired hysteria in the United States). 
her partner ${ }^{55}$ - they had in common the disastrous consequences that disclosure could bring.

Third, frequent disclosures of supposedly confidential HIV-related infonnation by medical personnel, employers, clinics, or others confirmed the fears of people affected by HIV. ${ }^{56}$ Although the precise number of such disclosures is undeterminable, perhaps more important than the actual number of unauthorized disclosures was the growing perception among affected populations-especially gay men - that breaches of confidentiality were common. This perception, coupled with the pre-existing mistrust discussed above, created powerful concerns that cooperating with aggressive public health programs was tantamount to giving up one's privacy and control and exposing oneself to discrimination, ostracism, and even violence..$^{57}$

Fourth, the need for public health officials to gain the trust and cooperation of affected groups in order to combat the epidemic underscored the importance of confidentiality. Early in the epidemic, most health officials recognized that efforts to control the spread of AIDS would be all but useless without the involvement and cooperation of the populations-especially gay inen-in which AIDS was inost present. $^{58}$ Cooperation was

55. Although the issue has yet to receive the attention and study required, it is clear that many HIV-positive women may become victims of domestic violence if and when male partners learn of their status. See Karen H. Rothenberg \& Richard L. North, The Duty to Warn "Dilemma" and Women with AIDS, 2 CTS. HEALTH ScI. \& L. 90 (1991).

56. See, e.g., Dennis Pfaff, AIDS Leaks Viewed as Symptom of Systemic Sickness, DAIlY J., Mar. 18, 1991, at 8, 8-9 (reviewing numerous instances of disclosures of confidential HIV-related information); see also AIDS, 59 U.S.L.W. 2668, 2668-69 (1991) (recounting story of HIV-positive hospital physician whose medical records were opened for review by all hospital employees); Seth Mydans, Names List Leads to Ethics Debate, N.Y. TIMES, July 30, 1991, at A10 (discussing doctor's disclosure of list of clients in HIV-related practice to political fundraiser). For additional citations regarding breaches of confidentiality, see Lawrence O. Gostin, The AIDS Litigation Project: A National Review of Court and Human Rights Commission Decisions, Part I: The Social Impact of AIDS, 263 JAMA 1961, 1965, 1969-70 nn.204-17 (1990).

Unauthorized disclosures of private medical information occur routinely outside the HIV context as well. In a highly publicized recent example, Congresswoman Nydia Velazquez found her previous suicide atteinpt splashed across newspapers after someone faxed her hospital records to the media. See Larry Tye, Privacy at Risk: Health Plans Face Data Access Issues, Boston Gloвe, Mar. 23, 1993, at 1.

57. These fears took shape within a society that has generally become more fearful that, in the advancing coinputer age, "personal" information may no longer be safe from undesired intrusion. See generally Jon D. Cohen, Comment, HIV/AIDS Confidentiality: Are Computerized Medical Records Making Confidentiality Impossible?, 4 SoFTwARE L.J. 93 (1990). Hospital medical records are typically seen by 80 people, and the growth in computerization of medical records threatens to increase greatly the number of persons who can aecess them. See Tye, supra note 56, at 10 . The widespread publicity given to instances of outsiders accessing supposedly secure databases has further fueled concerns about confidentiality. A group of tecnagers, for example, gamed access to the medical records of more than 6000 patients at the renowned Sloan-Kettering Cancer Center in New York. Id. at 108. Moreover, the possibility that imminent national health care reforms may mclude establishment of a national medical data bank has raised the specter of undesignated access to vast amounts of private medical information. See Sam Fulwood III, Fears for Privacy If Clinton Starts Medical Data Bank, S.F. Chron., Aug. 25, 1993, at A8.

58. For public health officials, whose legacy of anti-venereal disease campaigns included periodic sweeps of red-light districts and closure of houses of prostitution and whose control of epidemics had historically relied upon coercive state power, the ultimate challenge was to 
essential because control of the epidemic hinged on the willingness of individuals to bring themselves into contact with the health care system-that is, to be tested for HIV exposure, to undertake risk reduction behavioral changes, to notify partners voluntarily, and to access available treatments.

Public health officials thus learned that, in the context of the intense concerns of gay men about government intentions and the severe consequences of disclosure of HIV status, the guarantee of confidentiality was a prerequisite to encouraging affected populations to access the health care system. ${ }^{59}$ Because disclosure of an individual's HIV status could have such grave personal consequences, strong, unambiguous guarantees for the confidentiality of AIDS and HIV-related information became a cornerstone of public health efforts. Without such guarantees, the epidemic would be driven underground, putting individuals at risk and frustrating entirely the epidemic control efforts of the state. Possible models for the handling of HIV-related information ran along a spectrum from those inost protective of individual interests to those that were most aggressive and intrusive. In testing policy, for example, provision of publicly funded sites at which individuals could receive anonymous tests would provide maximum assurance to people that information about their HIV status would never even be linked to their identity. On the other end of the spectrum, testing sites could be required by state law to report the names of all individuals testing HIVpositive. In partner notification, policies could range from a completely voluntary system in which individuals would be encouraged to tell partners of possible exposure to a state-directed mandatory partner notification program.

During the first decade of the epidemic, the factors driving confidentiality concerns gave rise to a sometimes uneasy consensus among AIDS advocates, civil libertarians, and public health officials that less intrusive strategies would best serve the twin goals of safeguarding individual rights and advancing the public health. ${ }^{60}$ State statutes and regulations would

develop a language and practice of public health that would encourage the participation, rather than the resistance, of gay men.

BAYER, supra note 41 , at 21.

59. See Richard C. Turkington, Confidentiality Policy for HIV-Related Information: An Analytical Framework for Sorting Out Hard and Easy Cases, 34 Vill. L. REv. 871, 885 (1989). Although confidentiality concerns have certainly bcen present in efforts to control other epidemics, including venereal disease, the tremendous stigma and public hysteria associated with HIV infection distinguished confidentiality issues in the HIV context. See supra notes $46-54$ and accompanying text.

60. Influential public and private entities emphasized that confidentiality and the public health were mutually reinforcing goals. See Report of THE Presidential Commission, supra notc 53, at 126; see also John R. Dunne \& Gregory V. Serio, Confidentiality: An Integral Component of AIDS Public Policy, 7 ST. Lous U. PuB. L. Rev. 25, 33 (1988) (showing support for strict confidentiality policies from the Deputy Majority Leader of the New York State Senate and Co-chair of the New York State Senate Majority Task Force on AIDS); David L. Kirp \& Ronald Bayer, The United States at the Center of the Storm, in AIDS In the Industrialized Democracies: Passions, Politics, and Policies 43 (David L. Kirp \& Ronald Bayer eds., 1992) (noting that, because public health officials were "compelled to negotiate the course of the public health strategy with representatives of a well-organized 
strictly limit access to HIV-related information to a patient's physician or another member of a patient's medical team. Equally important, the individual would maintain control over the information; as a general rule, disclosure of HIV-related information would require the prior authorization of the individual.

It is crucial to note that although civil liberties concerns were also central, public health concerns largely explained the premium placed on confidentiality. Tight restrictions on the dissemination of any information about an individual's AIDS or HIV status would meet the concerns of advocates and affected groups by protecting an individual's privacy rights and ensuring that the individual could decide when and where HIV-related information would be disseminated. Yet such a strict policy was also expressly intended to promote public health goals by encouraging at-risk individuals to seek medical attention and to cooperate with health officials. ${ }^{61}$ Emerging evidence that fears about the confidentiality of HIVrelated information would keep at-risk people from accessing the health care system ${ }^{62}$ supported the notion that protection of civil liberties was complementary to, rather than in conflict with, protection of the public health.

Official recognition of the confidentiality imperative took many forms, including official policies and statutory enactments, as well as the overall shaping of public health strategy in response to AIDS. After a blood test for antibodies to HIV was developed in 1985, the federal government began funding testing sites across the country at which people could test anony-

gay community ... many of the traditional practices of public liealth, such as routine screening, reporting of HIV infection by name, and contact tracing were dismissed as inappropriate").

61. See, e.g., Partner Notification for Preventing Human Immunodeficiency Virus (HIV) Infection-Colorado, Idaho, South Carolina, Virginia, 37 MoRBIDITY \& MoRTALITY WKLY. REP. 393, 401 (1988) [hereinafter Partner Notification for Preventing HIV Infection] ("Confidentiality is essential to ensure that individuals at risk continue to seek counseling, testing, or partner-notification services.").

62. See, e.g., Laura J. Fehrs et al., Trial of Anonymous Versus Confidential Human Immunodeficiency Virus Testing, 2 LANCET 379 (1988) (indicating a significant increase in the number of testing registrants and a decrease in the time taken to decide to be tested when anonymous testing opportunities were available); E. James Fordyce et al., Mandatory Reporting of Human Immunodeficiency Virus Testing Would Deter Blacks and Hispanics from Being Tested, 262 JAMA 349 (1989) (letter to the editor); Susan M. Kegeles, Mandatory Reporting of HIV Testing Would Deter Men From Being Tested, 261 JAMA 1275, 1275-76 (1989) (letter to the editor); Rose Weitz, Anonymity in Testing for HIV Antibodies Desired Option, 81 AM. J. PuB. HeALTH 1213 (1991). Additional data suggests that people considered at relatively high risk for HIV exposure will get HIV tests in locations where their anonymity is ensured. See, e.g., State of Cal. Dep't of Health Servs., Brief Summary of 1991 HIV TEST DATA 4 ("the vast majority of gay/ Gay/IDU, Bisexual, and clients with HIVpositive sexual partners tested at alternative test sites" where they could choose to test anonymously); Fehrs et al., supra (noting that the number of gay men being tested increased significantly when anonymous testing option was available); Karolynn Siegel et al., The Motives of Gay Men for Taking or Not Taking the HIV Antibody Test, 36 Soc. ProBs. 368, 378-79 (1989); Colorado's Anonymous Test Site Has More HIV-Positive Results, AIDS PoL'y \& L. (Buraff Publications, Washington, D.C.), Oct. 16,1991 , at 7 (reporting that Colorado's single anonymous HIV-antibody testing site liad significantly higher rates of seropositivity). 
mously. ${ }^{63}$ The federal Centers for Disease Control and Prevention (CDC) required states to safeguard the confidentiality of HIV-related information as a condition of receiving federal AIDS funds. ${ }^{64}$ Many states enacted laws specifically desigued to prohibit the unauthorized disclosure of information related to an mdividual's HIV status. ${ }^{65}$ Virtually all jurisdictions that developed partner notification programs placed emphasis squarely on encouraging HIV-positive persons themselves, rather than the state, to notify sex and/or needle-sharing partners of their possible exposure. ${ }^{66}$

It is possible, however, to overstate the degree to which this consensus was complete. ${ }^{67}$ Some states, such as Colorado, provided almost no support for anonymous testing sites, and required reporting to the state of the names of people testing HIV-positive. ${ }^{68}$ Nonetheless, the basic model adopted for public health strategy against the epidemic focused on individual control of HIV-related information and de-emphasized the more aggressive public health measures characteristic of other communicable disease strategies.

\section{II}

\section{New Threats to the Confidentiality of HIV-Related INFORMATION}

\section{A. Strains on the Consensus}

Through the late 1980s and the early 1990s, the crucial confluence of opimion around public health strategy on the AIDS epidemic has come under increasing strain. More and more voices are calling for increased utilization of the kind of public health methods consciously avoided in the earlier formulation of AIDS policy, including mandatory name reporting of HIV positivity and aggressive partner notification. ${ }^{69}$ Several forces lie

63. See William L. Roper, Current Approaches to Prevention of HIV Infections, PuB. Health ReP., Mar.-Apr. 1991, at 111.

64. See Stephen Crystal et al., AIDS Contact Notification: Initial Program Results in New Jersey, 2 AIDS Educ. \& Prevention 284, 285 (1990).

65. See, e.g., Cal. HeAlth \& SAFETY CODE $\$ \$ 199.20-.27$ (West 1990 \& Supp. 1993); N.Y. Pub. Health Law $\$ \$ 2780-2787$ (McKinney Supp. 1993); Pa. Stat. AnN. tit. 35, $\S 7601-7612$ (West 1993).

66. See, e.g., Association of State \& Terrtorial Health Officials et al., Guide to Punlic Health Practice: Partner Notification Strategies 3, 13-15 (1988) (establishing minimal expectations for partner notification programs, stressing the importance of obtaining voluntary cooperation of the index patient in notifying sexual partners and outlining narrowly drawn circumstances in which partner notification can occur without the cooperation of the index patient); Crystal et al., supra note 64, at 285.

67. For example, the federal government instituted mandatory screening programs for particular populations including immigrants, members of the armed forces, and foreign service officers. See Gostin, supra note 56, at 1962.

68. See Judson \& Vernon, supra note 43, at 388-90.

69. See, e.g., Marcia Angell, A Dual Approach to the AIDS Epidemic, 324 NEw ENo. J. MED. 1498 (1991) (showing the editor of a leading medical journal's advocacy of a nationally funded HIV program with systematic tracing, partner notification, and screening of certain groups). 
behind this shift in opinion. Most importantly, the AIDS epidermic continues to spread. Not surprisingly, inany public health officials and others want to deploy new methods to coinbat the epidemic. ${ }^{70}$ Aggressive measures, at least, can give the appearance that the epidemic is being dealt with vigorously. People have raised new questions regarding the scientific and medical wisdom of less intrusive strategies, insofar as some evidence suggests that at-risk people might be aided by more aggressive public health strategies. For example, several studies have suggested that partner notification programs might help combat the spread of HIV by allowing officials to identify and contact some persons at high risk of exposure. ${ }^{71}$ Other studies have indicated that relatively few HIV-positive persons take it upon themselves to notify their partners of possible exposure, suggesting that notification systems built entirely on the voluntary efforts of HIV-positive individuals would be unsuccessful. ${ }^{72}$ Proponents of aggressive contact tracing programs claimed that experience demonstrated that such efforts could save both lives and money. ${ }^{73}$

But the evidence on the efficacy and cost-effectiveness of aggressive public health efforts for HIV falls well shy of overwhelming. Indeed, numerous studies have suggested that aggressive impleinentation of such programs might deter people from getting tested in the first place. ${ }^{74}$ Such

70. See Ronald Bayer, Public Health Policy and the AIDS Epidemic-An End to HIV Exceptionalism?, 324 NEw ENG. J. Med. 1500, 1502 (1991) ("As the first decade of the epidemic came to an end, public health officials began to reassert their professional dominance over the policy-making process and in so doing began to rediscover the relevance of their own professional traditions to the control of AIDS.").

71. See, e.g., Partner Notification for Preventing HIV Infection, supra note 61 (reviewing state data suggesting that partner notification programs inay successfully identify infected persons and bring them into contact with the health care system); Public Health Uses of HIV-Infection Reports-South Carolina, 1986-1991, 41 MORBIDITY \& MORTALITY WKLY. REP. 245, 246-48 (1992) [hereinafter Public Health Uses of HIV-Infection Reports] (estimating that $263 \mathrm{HIV}$-positive partners were identified through the South Carolina partner notification program, and projecting that such identifications would result in a cost savings of $\$ 13$ million if each person notified would have infected one other person but did not as a result of the reporting program).

72. See, e.g., Gary Marks et al., HIV-Infected Men's Practices in Notifying Past Sexual Partners of Infection Risk, PUB. HEALTH REP., Jan.-Feb. 1992, at 100 (reporting low levels of notification of past sexual partners by seropositive men).

73. See, e.g., Judson \& Vernon, supra note 43 (describing experience of Colorado partner notification program); Edward P. Richards, Communicable Disease Control in Colorado: A Rational Approach to AIDS, 65 DENv. U. L. REv. 127 (1988) (reviewing Colorado's aggressive AIDS control program and portraying those opposed to it as "rooted in a naive view of disease control").

74. See supra note 62 and accompanying text. This deterrent effect may be especially strong for people in higher-risk groups, especially gay and bisexual men. See Margaret Carmen et al., Factors Influencing Trends in the Use of Real Names and ldentifiers at an HIV Counseling and Testing Site (CTS) in Minnesota, in 2 ABstracts, SxTh INTERNATIONAL CoNFERENCE on AIDS 456 (1990) (indicating that $72 \%$ of gay and bisexual men reported being "frigltened" of contact tracing efforts by the state); Douglas Mirano et al., Impact of a 1989 Testing Policy Change in Arizona: Preliminary Analysis, in 2 ABstracts, SEXTH InTERNATIONAL CONFERENCE on AIDS 249 (1990) (rccording a jump of more than $37 \%$ in the number of gay and bisexual men testing when Arizona opened an anonyinous testing site); David Cohn et al., HIV ABonymous Test Site Evaluation (Oct. 5, 1992) (unpublished manuscript, on file with author) (concluding that the opening of an anonymous testing site in Denver 
empirical indications have raised serious questions as to the overall value of aggressive public health measures in the fight against AIDS. Nevertheless, enough evidence of possible utility for more sucli efforts has emerged to provide at least some empirical justification for placing new emphasis on them.

Empirical data has not, however, provided the only spur to the resurgence of aggressive public health programs. Another came from the desire of the CDC and other public health agencies for more complete and accurate surveillance data on the epidemic. The agencies maintained that they could construct a more comprehensive and useful picture of the epidemic by requiring the reporting of all names of HIV-positive persons to the state and tracking possibly exposed partners of known HIV-positive persons. ${ }^{75}$ The trend toward greater use of aggressive public health approaches may also be driven by the blunting of the major prevention weapon-education-by repeated political battles over the content, targeting, and intensity of educational messages. ${ }^{76}$ At the same time, a handful of HIV transmission "horror stories" have put intense pressure on politicians and public health officials to take more aggressive steps against the spread of HIV. ${ }^{77}$ Finally, the release of modestly effective HIV treatments such as AZT and the growing evidence that early detection of infection can delay the onset of

induced significant numbers of gay and bisexual men to seek out testing who had previously avoided the system on account of confidentiality fears); see also N.E. Spencer et al., Partner Notification for HIV Infection in Colorado: Results Across Index Case Groups and Costs, 4 INT'L J. STD \& AIDS 30 (1993) (worrying that $35 \%$ of gay men did not identify partners in partner notification programs).

75. The CDC uses "surveillance" essentially to mean the systematic collcction of data in order to monitor disease trends, allocate resources appropriately, and identify needs of particular populations. Public Health Uses of HIV-Infection Reports, supra note 71, at 245. For a general discussion of surveillance, see Robert M. Politzer \& C. Howard Davis, HIV/AIDS Surveillance: Revelation at the Margin, 5 AIDS \& PuB. PoL'y J. 29 (1990).

76. Although conservatives have had only limited success with respect to confidentiality issues, they have exerciscd disastrous influence over the content and form of HIV education campaigns. See supra note 16 and accompanying text.

77. The case of Kinberly Bergalis, a young Florida woman infected by her dentist, led to a wave of national hysteria over HIV-infccted health care workers. See Jacob Weisberg, The Accuser: Kimberly Bergalis, AIDS Martyr, New REPuBLIC, Oct. 21, 1991, at 12 (describing hysteria inspired by the Bergalis case and its manipulation by right-wing lawmakers). Subsequent to the Bergalis case, whether and under what circumstances health care workers and patients should be subject to mandatory testing and disclosure requirements became-and remains still-a matter of volatile controversy. See Jean Latz Griffin, AIDS Test: Who's Next?, CHI. TRIB., Aug. 4, 1991, § 4, at 1. Approxinuately 90\% of all patients want to know the HIV status of their doctor. Id. Among the arguments against systematic efforts to identify and contact the patients of HIV-positive physicians (or other health care providers) is that such programs are unlikely to identify unaware infected people and will be very costly and violative of personal privacy and civil rights. See, e.g., Richard N. Danila et al., A Look-Back Investigation of Patients of an HIV-Infected Physician, 325 New ENG. J. MED. 1406, 1409 (1991) (finding no HIVpositive former patients of HIV-positive physician at a cost of nearly $\$ 130,000$ ); No Instances of HIV Transmission Found in Three Look-Back Studies, JAMA Reports, AIDS PoL'y \& L. (Buraff Publications, Washington, D.C.), Apr. 30, 1993, at 1, 6. For a study and discussion of the societal and financial costs of the health care worker hysteria, see Benjamin Schatz, "May God and the Community Help Us All": Results of a Survey of HIV-Positive and "High-Risk" Untested Health-Care Workers, 7 AIDS \& PuB. PoL'y J. 71 (1992). 
symptomatic AIDS have inspired a greater einphasis on identifying people at risk of infection and encouraging them to be tested. ${ }^{78}$

All of these factors have led to a growing tide of public health opinion favoring intrusive and aggressive public health measures. For example, a 1991 editorial in one of the nation's leading medical journals called for "systematic tracing" of HIV-positive persons' sexual partners, and routine HIV screening of hospital patients, health care workers, and pregnant women. ${ }^{79}$ Similarly, a 1990 American Medical Association resolution called for implementation of AIDS control measures paralleling those used for sexually transmitted diseases, including partner notification and testing without informed consent. ${ }^{80}$ The Bush administration actively considered requiring states to impose mandatory reporting of all cases of HIV infection and aggressive partner notification policies. ${ }^{81}$

State and federal AIDS policies directly reflect this trend, as evidenced by significant policy shifts regarding testing, name reporting, partner notification, and contact tracing. More states are cutting support for anonymous testing sites. ${ }^{82}$ Moreover, an increasing number of states require health care providers and laboratories that run HIV antibody tests to report the names

78. The great weight of medical opinion now favors early identification for monitoring and managing HIV. See Brett-Smith \& Friedland, supra note 15, at 40; Publicly Funded HIV Counseling and Testing-United States, 1990, 40 Morbidity \& MORTALITY WKLY. REP. 666, 668-69 (1991). Accordingly, not only public health officials but community-based AIDS organizations have encouraged voluntary testing for several years. This position marks a dramatic shift on the part of AIDS organizations-and gay and lesbian rights groups-from their former firm opposition to testing. See BAYER, supra note 41, at 101-36. The frightening resurgence of tuberculosis in the United Statesespecially of strains resistant to current treatunents-provides another significant rationale for voluntary tcsting, as HIV-positive people can be especially susceptible to developing active, life-threatening TB upon infection with the TB agent. See Tuberculosis Outbreak Among Persons in a Residential Facility for HIV-Infected Persons-San Francisco, 40 MORBIDITY \& MORTALITY WKLY. REP. 649 (1991); AIDS Group Calls for TB Initiative, Says Disease Represents "Emergency," AIDS PoL'Y \& L. (Buraff Publications, Washington, D.C.), Apr. 2, 1992, at 7; Deaths Involving TB Are Rising; Connection to HIV/AIDS Cited, AIDS PoL'Y \& L. (Buraff Publications, Washington, D.C.), July 9, 1993, at 5.

However, the persuasiveness of the availability of early treatment as a rationale for identifying HIV-positive people is diminished by the fact that many people, especially lower-income people and people of color, lack access to care. See, e.g., Johns Hopkins Study Finds Majority, Mainly Black, Poor, Not Taking AZT, AIDS PoL'Y \& L. (Buraff Publications, Washington, D.C.), May 29, 1991, at 3. Moreover, there is now some evidence suggesting that AZT, long considered the most useful available drug treatment, may have only short-term health benefits for HIV-infected people. Sheryl Stolberg, AIDS Study Casts Doubt on AZT as a "Miracle Drug," L.A. Trmes, June 9, 1993, at A1.

79. Angell, supra note 69, at 1500; see also Stephen C. Joseph, Premarital AIDS Testing: Public Policy Abandoned at the Altar, 261 JAMA 3456 (1989) (showing that the New York Commissioner of Hcalth predicted a more aggressive HIV strategy, including increased contact tracing and a registration program); Thomas C. Quinn, Screening for HIV Infection-Benefits and Costs, 327 NEw ENG. J. MED. 486 (1992) (advocating increased use of HIV screening of hospital patients).

80. Joyce Price, Put Health Before Politics in AIDS Fight, AMA Urges, Wash. Times, Dec. 24, 1990, at A6.

81. Laurie Garrett, Bush Considers Plan Requiring All Cases of HIV Be Reported, HoustoN Chron., July 15, 1992, at A8.

82. See, e.g., New Tennessee Rule Eliminates All Anonymous Testing for HIV, AIDS PoL'y \& L. (Buraff Publications, Washington, D.C.), Jan. 9, 1992, at 2; N.C. Votes to Trim Anonymous Test Sites; Will Eliminate Procedure Totally in 1994, AIDS PoL'y \& L. (Buraff Publications, Washington, D.C.), 
of all HIV-infected people. ${ }^{83}$ Several states have also stepped up their efforts to trace and contact the sexual and needle-sharing partners of HIVpositive people. ${ }^{84}$

The federal government has long encouraged and financially supported state name reporting, contact tracing, and partner notification programs. Recently, however, the CDC has begun to promote such efforts more strongly. ${ }^{85}$ For example, the $\mathrm{CDC}$ has gradually increased its requirements that states implement partner notification programs as a condition of receiving federal AIDS funds. In 1988, it mandated only that states "encourage" HIV-positive persons to refer their partners for testing. ${ }^{86}$ In 1989, the CDC required states to "[e]stablish standards and implement procedures" for

Feb. 20, 1991, at 1; States Said Moving Away From Anonymous Testing, AIDS PoL'Y \& L. (Buraff Publications, Washington, D.C.), Feb. 21, 1990, at 5.

83. See, e.g., Identities of HIV-Positive Required by New Jersey Law, AIDS PoL'Y \& L. (Buraff Publications, Washington, D.C.), Feb. 7, 1990, at 4; Name Requirement to Take Effect at Beginning of Year in Georgia, AIDS PoL'y \& L. (Buraff Publications, Washington, D.C.), Sept. 18, 1992, at 4; see also Texas Proposal Would Require Reporting of HIV-Positive People, AIDS PoL'Y \& L. (Buraff Publications, Washington, D.C.), June 26, 1992, at 5 (discussing proposed rule). At least one state, Colorado, even keeps lists of the names of those who test HIV-antibody negative. Colorado Keeping List of Names of Those Testing HIV Negative, AIDS PoL'Y \& L. (Buraff Publications, Washington, D.C.), Aug. 7, 1991, at 3.

Today, 38 states require some form of reporting. Of these, 12 require reporting only by name, and 12 others use reporting principally by name, with other demographic information included. Lisa Bowleg, Results from the 1992 AIDS Pol'y Ctr. HIV Reporting Survey, INTERGOVERNMENTAL AIDS REP. 3, 4 (AIDS Pol'y Ctr., Washington, D.C.), Oct. 1992, at 3, 4. Significantly, the great majority of states requiring name reporting are lower incidence states. Of higher incidence states, only New Jersey has name reporting. Centers for Disease Control, HIV INFEction REPORTING IN THE UNITED States (1993).

The practice in some states of requiring name reporting and providing only limited opportunities for anonymous testing tends to undermine the claimed goal of iniproved surveillance and data collection. Similarly, many nonanonymous testing sites do not require identification; therefore, those being tested can use pseudonyms and/or fictitious addresses. While these loopholes may subvert the claimed rationale for moving away from anonymous testing, they also preserve some of the confidentiality advantages of anonymous testing. Nevertheless, some of those contemplating testing may be unaware that they can use a pseudonym, and therefore may still be deterred from testing in a confidential (rather than an anonymous) setting.

84. See, e.g., Missouri's Level Infection Rate Attributed to Tracking Program, AIDS PoL'y \& L. (Buraff Publications, Washington, D.C.), Aug. 7, 1992, at 6; Mireya Navarro, New York City Widens Plan to Warn of AIDS Exposure, N.Y. TIMEs, Mar. 17, 1991, at 32; Michele L. Norris, District Reaching Out to Track HIV Cases, WASH. Post, Oct. 13, 1992, at A1, A6. The extent to which partner notification and contact tracing can be made mandatory is, of course, limited by the dependence of such efforts on the index patient's voluntary cooperation (i.e., the divulgence of names). Also, adding any degree of "mandatoriness" to the process, such as a requirenient to divulge names, may actually decrease cooperation. See M.L. Rekart et al., Patient Referral or Provider Referral Partner Notification: Which Do Patients Prefer?, in 2 Abstracts, Sixth InTERnational Conference on AIDS 121 (1990).

85. In 1990, the CDC editorialized that "the implcmentation of a standardized system for HIV reporting to state health departments can enhance the ability of local, state, and national agencies to project the levels of required resources" and develop partner notification programs. Update: Public Health Surveillance for HIV Infection-United States, 1989 and 1990, 39 MoRBIDITY \& MoRTALrTY WKLY. REP. 853, 861 (1990). More concretely, the CDC has provided funding to statcs to assist them in establishing and implementing name reporting systems. See infra note 89 and accompanying text.

86. 52 Fed. Reg. 7028, 7030 (1987). 
partner notification. ${ }^{87}$ By 1990 , states were required to offer official assistance in contacting partners of HIV-positive persons. ${ }^{88}$ The CDC has also encouraged states to adopt mandatory HIV reporting, making HIV positivity, rather than just full-blown diagnosed AIDS, a reportable medical condition. The CDC recently underscored this federal policy by providing funding to New Jersey for a new mandatory name reporting system for HIV status. ${ }^{89}$

\section{B. Implications for Confidentiality}

The importance of confidentiality in fighting AIDS remains as strong as it ever was in the 1980s - and for many of the same reasons. Individuals with AIDS and HIV still face discrimination and ostracism based on their medical condition. ${ }^{90}$ Improper disclosures of HIV-related information still occur. ${ }^{91}$ Moreover, the trust and cooperation of people at risk of infection - or in need of medical treatment for HIV-related conditions still depends on the airtight quality of confidentiality. In the unique context of fear, discrimination, and ostracism which surrounds the AIDS/HIV epidemic, the perceptions of imdividuals affected by HIV matter as much as the reality of confidentiality protections. These people must trust that the health care system will zealously guard their interests. Loss of that trust will lead people to avoid contact with the system entirely, with serious ramifications both for those individuals' health and for the public health in general.

The increasing use of aggressive communicable disease control measures to combat the spread of AIDS raises new concerns about confidentiality. At a minimum, this development means that more information about more people with HIV will be used for more purposes. Although a greater number of unauthorized or damaging disclosures may not necessarily result,

\footnotetext{
87. 53 Fed. Reg. 3554, 3555 (1988).

88. Bayer \& Toomey, supra note 21 , at 1160 .

89. Identities of HIV-Positive Required by New Jersey Law, supra note 83, at 4; Name Reporting Still Stings, 5 AIDS UpDaTE 16 (Lambda Legal Def. \& Educ. Fund, New York, N.Y.), Oct. 1992.

90. See, e.g., "Alarming" Responses Found in National Poll Surveying Employee Responses to AIDS, AIDS PoL'Y \& L. (Buraff Publications, Washington, D.C.), Apr. 2, 1993, at 1 (revealing that between one-quarter and two-thirds of workers polled nationally would not want to work near an employee with HIV); HIV-Positive Druggist's "Driving Force," N.Y. NEwSDAY, May 6, 1992, at 89 (showing how an HIV-positive pharmacist faced a breach of confidentiality and employment discrimination); Judge Awards Custody of Child to Mother from HIV-Positive Father, AIDS PoL'Y \& L. (Buraff Publications, Washington, D.C.), Feb. 5, 1993, at 3 (revealing how a father's HIV status caused him to lose custody of his daughter); Wade Lambert, Discrimination Afflicts People with HIV, WALL ST. J., Nov. 19, 1991, at B1; Susan Orenstein, An AIDS Story, Recorder, Aug. 26, 1992, at 1 (describing how an attorney's HIV status may have led to discrimination and termination); Survey Says a Fourth of Dentists Would Not Treat AIDS Patients, AIDS PoL'Y \& L. (Buraff Publications, Washington, D.C.), Jan. 23, 1991, at 6.

91. See, e.g., Increase in Rights Violations Noted Among HIV-Positive Professionals, AIDS PoL'Y \& L. (Buraff Publications, Washington, D.C.), Jan. 9, 1992, at 7 (discussing HIV disclosures in workers' compensation inedical reports); Tennessee Doctor Reprimanded, Fined for Disclosure of HIV, AIDS PoL'Y \& L. (Buraff Publications, Washington, D.C.), Oct. 2, 1992, at 5 (describing a doctor's unauthorized disclosure of his patient's HIV-positive status to the patient's employer).
} 
breaches of confidentiality by negligent or deliberate disclosure of information will becoine increasingly possible with the proliferation of name reporting and partner notification. Moreover, the availability to the state of more sensitive information poses the danger that the state will use this information in a manner which breaches confidentiality.

For example, the existence of state registries of HIV-positive people, coinpiled through inandatory name reporting programs, siginficantly affects both the access and control dimensions of confidentiality. The state-and whoever has the authority of the state, such as state einployees-has access to lists of HIV-infected people. Of equal importance, name reporting shifts the locus of control over the information. No longer can an individual tested for HIV exposure decide to whom and under what circumstances the test result is communicated. Instead, if that test is positive, the result is automatically registered with the state. The individual has no control over the information-except to choose not to get tested at all, or to do so at an anonyinous testing site. ${ }^{92}$

The availability of anonymous testing is, of course, incompatible with a real program of mandatory name reporting, since anonyinity makes naine reporting, by definition, impossible. Thus, name reporting as a public health goal may well conflict with state HIV testing policies that allow for anonymous testing opportunities. The removal of anonymous testing sites, on the other hand, poses the danger of driving people away from the health care systein. The inere institution of mandatory name reporting programs, then, inay have precisely the result that both public health officials and AIDS advocates want to avoid: deterring at-risk persons from learning their FIV status and taking appropriate steps to monitor their health and reduce the chances of further transmission of the virus.

Moreover, the influence which the vicissitudes of politics and public policy have on AIDS policy raises the specter that the state will allow use of registries-as a matter of "public policy"-for purposes other than disease monitoring and surveillance. ${ }^{93}$ Recent occurrences in Illinois provide a glaring case in point.

In 1991, the Illinois legislature passed a statute permitting the state to cull its registry of HIV-infected persons to identify all those einployed as health care workers. ${ }^{94}$ The statute then allowed the state to notify

92. See supra notes $62-63$ and accompanying text; supra note 74; see also Name Reporting Still Stings, supra note 89, at 15, 17 (discussing reports from Colorado and South Carolina that show lack of anonymous testing sites has inhibited testing or contributed to out-of-state testing).

93. Mandatory name reporting is most frequently justified as a means of accurately crenting nonduplicative records of the numbers of HIV-positive persons, i.e., as an aid in disease surveillance. "Nonsurveillance uses" indicates use for any purpose other than monitoring incidence and disease trends.

94. InL. Ann. Stat. ANn. ch. 410, § 325/5.5 (Smith-Hurd 1993); see also Notification Measure Signed in Ill.; Cost, Effectiveness Still Debated, AIDS PoL'y \& L. (Buraff Publications, Washington, D.C.), Oct. 16, 1991, at 2. 
patients-the names of whom would be drawn retrospectively from hospital records-who had been involved in "invasive procedures" with HIVinfected providers of their possible exposure, and to notify health care workers of possible exposure from patients. The Ilinois law brings to hfe inany of the deepest concerns surrounding the fragility of confidentiality protections. First, it was passed despite overwhelming evidence that the program would identify few, if any, HIV-positive persons. ${ }^{95}$ Second, its enactment suddenly inade intensely personal inedical records of health care workers and patients alike open to scrutiny, to which the affected persons had given no consent whatsoever, much less informed consent. Third, such a program would almost certainly deter health care workers from voluntarily seeking HIV testing. ${ }^{96}$ Thus, at enormous cost, the program would achieve little while profoundly injuring privacy interests and deterring voluntary testing. The measure was signed imto law, but, after intense pressure froin AIDS advocates, medical professionals, and others, the act received only $\$ 1.00$ in funding, rendering it effectively inactive. ${ }^{97}$ Nonetheless, the law remains on the books.

More importantly, the Illinois example illustrates the kind of purposes to which legislatures might put registries should the political atınosphere so permit or encourage. Although few states have comparable legislation pending, a single sensational case of, say, physician-to-patient transmission could trigger a public outcry for aggressive action to control HIV. ${ }^{98}$ In those states with registries of HIV-positive persons, the privacy rights of listed persons will become vuhierable to legislators looking to score political points with HIV-related laws. Such laws might also be inspired by motivations other than political opportumisin, as some politicians and public officials may promote them in a sincere-if misguided-effort to control HIV. The threat that the state inay use the information it collects in a way

95. The program would be highly unlikely to identify HIV-positive persons because the risk of transmission in health care settings is infinitesimally low. See supra note 77; see also NATiONAL Comm'n on AIDS, Preventing HIV Transmission in Health Care Settings 2 (1992) (concluding that "during literally millions of patient-health care worker interactions ... neither surveillance nor [32 look-back] studies have found a single patient with HIV infection resulting from care given by an infected health care worker.").

96. See Fear Keeps Most "High-Risk" HCWs from Seeking Treatment, Insurance, AIDS PoL'y \& L. (Buraff Publications, Washington, D.C.), Oct. 16, 1991, at 9 (reporting on survey of HIV-positive health care workers at relatively high risk of infection, and finding that three-fourths fear losing their jobs and two-thirds have avoided getting medical care because of confidentiality fears).

97. Mike McKee, Redefinition of AIDS May Put Privacy at Risk, Legal Times, Mar. 15, 1993, at 10.

98. See, e.g., Robert J. Blendon et al., Public Opinion and AIDS: Lessons for the Second Decade, 267 JAMA 981, 984 (1992) (summarizing results of several national opinion polls in which $80 \%$ of those polled favored mandatory testing of individuals in high-risk groups; almost 50\% favored universal testing; and nearly 90\% supported contact tracing); Robert Steinbrook, AIDS Fear Drops, Attitudes Harden, L.A. TmMEs, July 16, 1989, § 1, at 1, 28 (indicating that almost $80 \%$ of those polled support contact tracing and partner notification programs, and $60 \%$ favor mandatory testing of all members of high-risk groups). 
which harms the interests of people contemplating testing will deter some people from testing despite the health advantages.

More aggressive partner notification programs present similar public health and civil liberties concerns. Such programs, by definition, require the state to handle sensitive information not only about people's actual and potential HIV positivity, but also about their sexual and needle-sharing partners. As with name registries, such information could be subject to political or legislative intrusion. However, an important difference with partner notification is that the locus of control over the information reinams largely with the individual; partner notification depends entirely on the voluntary divulgence of information by the index patient. This gives individuals the option-at least in theory-of refusing to cooperate with the state program by not revealing partners' names. ${ }^{99}$

In sum, the early years of the epidemic's second decade bring two distinct sources of threats to confidentiality. First, the risk of negligent or intentional breaches of confidentiality rises with the increase in and added uses of highly sensitive HIV-related information in state hands. Second, the accumulation of such information in state hands may be employed for purposes wholly distinct from-even inimical to-the surveillance and disease control objectives used to justify its gathering. HIV remains a politically as well as epidemiologically volatile disease: thousands of names in state records provide an inviting target for those who believe that the government has done too little to actively control those with HIV. As the Illinois experience denronstrates, ${ }^{100}$ such information can serve purposes damaging both to the individuals affected and to the goals of public health.

\section{The Redefinition of AIDS}

In January 1993, the CDC revised its definition of AIDS, expanding the list of conditions that qualify as AIDS-defining and thereby adding tens of thousands of people to the list of people with AIDS. ${ }^{101}$ Since 1987, the CDC had defined AIDS as the presence of HIV antibodies and the manifestation at least two of twenty-three specific opportunistic infections associated with immune system suppression due to $\mathrm{HIV}{ }^{102}$ In response to criticism that this definition failed to include a nunber of AIDS-related

99. Participants' perceptions, however, may be that cooperation is not voluntary. See infra text accompanying notes $282-83$.

100. See supra notes $94-97$ and accompanying text.

101. Kenneth G. Castro et al., 1993 Revised Classification System for HIV Infection and Expanded Surveillance Case Definition for AIDS Among Adolescents and Adults, 41 MorbIDITY \& MORTALTY WkIY. REP., Dec. 18, 1992, at 8 [hereinafter 1993 Revised Classification System]. The CDC cstimates that the new defintion could cause the number of AIDS cases reported in 1993 to jump by $75 \%$ over the level expected under the old definition. If all HIV-positive persons in the United States were tested, and their immune status were known, the new definition would theoretically add between 120,000 and 190,000 people to AIDS registries. Id.

102. Revision of the CDC Surveillance Case Definition for Acquired Immunodeficiency Syndrome, 38 MORBIDITY \& MORTALITY WKLY. REP. 1 (1987). 
disorders, especially ones affecting women, ${ }^{103}$ the CDC implemented a revised definition for AIDS that became effective in January 1993. ${ }^{104}$ In addition to including three new opportunistic infections, ${ }^{105}$ the revised definition allows an AIDS diagnosis when a person tests positive for HIV antibodies and has a CD4 lymphocyte blood count of 200 or less. ${ }^{106}$

This simple redefinition, in addition to expanding the ranks of people with AIDS, has worrisome implications for the confidentiality of HIVrelated information. Such implications are magnified by the coincident inove toward greater use of aggressive public health measures. In short, the new use of CD4 information increases the opportunities for both purposeful and inadvertent disclosure of individuals' HIV or AIDS status. There are several points of concern.

First, the sheer increase in the number of reported cases may stress the confidentiality mechamisms in place in many jurisdictions. Second, and perhaps more inportantly, the redefinition means that public and private entities will possess a crucial new piece of HIV-related information and begin handling such information at an earlier stage. With the new significance of CD4 information, ${ }^{107} \mathrm{CD} 4$ tests are likely to become increasingly routine aspects of $\mathrm{HIV}$ treatment, especially soon after $\mathrm{HIV}$ infection is found. ${ }^{108}$ While such routine use is, as a general rule, medically desirable,

103. See, e.g., Kathleen D. Stoll, Center for Women Pol'y Stud., Women and the DefINITION of AIDS 1 (1992) (criticizing 1987 CDC definition for not including wounen-specific opportunistic infections).

104. 1993 Revised Classification System, supra note 101; see also Lawrence K. Altman, Federal Health Officials Propose an Expanded Definition of AIDS, N.Y. TmEs, Oct. 28, 1992, at A11.

105. The three added opportunistic infections are recurrent pneumonia, invasive cervical cancer, and pulnonary tuberculosis. 1993 Revised Classification System, supra note 101, at 6-7.

106. Altman, supra note 104, at A11. CD4 cells are critical elements in the body's immune capaeity and are reduced progressively by HIV infection. A nonimmune suppressed CD4 count lies in the neighborhood of 1000 . See Bernard M. Branson, The Role of CD4+ Cells in Immune System Function, PAACNOTES, Mar.-Apr. 1992, at 76, 77. A CD4 count below 200 is generally thought to represent severe immune system suppression. 1993 Revised Classification System, supra note 101, at 6. However, a major European study reported at the 1993 International AIDS Conference in Berlin cast some doubt on the scientific reliability of using CD4 counts as surrogate markers for asyinptomatic individuals. Lawrenee $\mathrm{K}$. Altman, AIDS Drugs: Does Haste Make Waste?, Houston ChroN., Apr. 19, 1993 , at 8 .

107. CD4 blood count information has been, for a number of years, important in monitoring HIVinfected individuals' immune system strength in clinical trials of AIDS medication. See Jon Cohen, Searching for Markers on the AIDS Trail, 258 SCIENCE 388 (1992). The redefinition of AIDS adds significance which lies principally outside the clinical area. The role of a CD4 count as an indicator of immune system suppression makes it valuable information for a variety of parties, including states (which wish to attract federal fuuds by maximizing the number of diagnosed AIDS cases), and employers and insurers (who may be interested in the health of employecs, insured persons, or applicants for employment or insurance).

108. In reality, CD4 testing may not be financially feasible for many people. CD4 tests are expensive, and unless significant subsidies are provided to low-income persons, many will be unable to afford such monitoring. See Letter from Paul A. Di Donato, AIDS Legal Referral Panel et al., to John Ward, Acting Chief of Surveillance, Division of HIV/AIDS, CDC 9 (Nov. 12, 1992) (on file with author) (discussing the need for public funding of CD4 testing to provide access to low-income and un/ underinsured people). 
it also means that the state is likely to obtain CD4 information earlier than it acquired AIDS information under the old definition. Adding more such bits of data to the pool of HIV-related information simply adds, in a more or less mathematical way, to the possibilities for disclosure.

Third, the number of HIV-infected persons whose names are recorded with public agencies will increase sharply as a result of the redefinition of AIDS. All states require reporting of persons diagnosed with AIDS, and the new definition promises to swell the state registries of such persons. ${ }^{109}$ Furthermore, states are certain to redouble their efforts to identify and record the names of people with AIDS. Two major federal AIDS programs that distribute funds to states, the Ryan White Comprehensive AIDS Resources Emergency Act and the AIDS Housing Opportunities Act, both allocate funds largely on the basis of the number of reported AIDS cases. Accordingly, states have a strong incentive to encourage identification and reporting of all AIDS cases. ${ }^{110}$ In fact, states are increasingly fighting a case-finding battle, with the prize of more federal dollars going to the "winners." The redefinition opens a new battleground to states, resulting in an increase in the data in state hands and raising the specter of added risk of disclosure.

Fourth, the 1993 redefinition of AIDS means, in essence, that an AIDS case can be "counted" as the result of two laboratory tests, HIV-antibody and CD4. A physician's diagnosis of AIDS-defining opportunistic conditions like pneumocystis pneumonia or invasive cervical cancer is not necessary. Therefore, states have the means available to count an AIDS case based solely on laboratory information. The most efficient way to get those - pieces of information is to have the laboratories that run HIV-antibody and CD4 tests report AIDS-qualifying results directly to the state. Many states may require that testing laboratories report sub-200 CD4 results directly to the state ${ }^{111}$ instead of having a physician forward the information. By taking the reporting function out of the hands of physicians, such a system removes reporting from the context of the doctor-patient relationship, thereby increasing the likelihood that AIDS diagnoses will effectively be made by laboratories and not be slared with patients in a medically and

109. See supra note 101 .

110. See, e.g., Memorandum from the California Department of Health Services to County Hcalth Officers et al. 1 (Mar. 5, 1992) (on file with author) (citing importance of generating full AIDS case reporting to ensure maximum federal grant receipts for state).

111. See, e.g., Letter from Elizabeth B. Cooper et al., American Civil Liberties Union, to James O. Mason, Assistant Secretary for Health, Department of Health and Human Services 4-5 (May 29, 1992) (on file with author) (discussing prospect of direct laboratory reporting of sub-200 CD4 tests to the state in New York). At least one state, Pennsylvania, instituted lab-based CD4 reporting and then rescinded the order under pressure from advocates concerned about confidentiality. See Pennsylvania Policy on Reporting Names of AIDS Patients on Hold, CH1. TrIB., Feb. 5, 1993, at 7. 
psychologically appropriate setting. ${ }^{112}$ Moreover, direct laboratory reporting of CD4 testing inay be a precursor to more states requiring direct laboratory reporting of HIV-positive test results. ${ }^{13}$

All of these confidentiality concerns are critically important because CD4 information is widely uscd as a "marker" for AIDS/HIV. CD4 blood counts provide perhaps the most accurate gauge available for evaluating a person's immune system. ${ }^{114}$ Doctors and insurers, who already use CD4 information as a inarker for HIV infection, ${ }^{115}$ will likely expand such use in the wake of the redefinition of AIDS, which inplies official recognition of the utility of CD4 information and will result in increased CD4 testing. ${ }^{116}$

Despite urging by advocacy organizations, ${ }^{117}$ the CDC has steadfastly refused to balance its redefinition of AIDS with adequate measures to ensure the confidentiality of CD4 information. This inay be due to the CDC's longstanding desire to beef up the data collection aspects of its strategy against AIDS. Although the agency originally agreed to the confidentiality protections called for under the consensus discussed above, ${ }^{118}$ it has over the years tried to weight the balance more heavily towards data collection. Furthermore, the CDC is not just passively neglecting the CD4 confidentiality issue; it is actively making policy decisions that affect the ways in which such information will be treated. For exaniple, the CDC has declined to earmark federal funds to develop test sites for anonyınous CD4 testing similar to those it funded for anonymous HIV-antibody testing. Without such sites, CD4 testing will be conducted primarily by private pliysicians, clinics, and labs that offer confidential-but not anonyinous (i.e., where no

112. See Memorandum from Paul Di Donato, Policy Director, AIDS Legal Referral Panel \& Elizabeth B. Cooper, Gibbons Fellow in Public Interest and Constitutional Law, Crummy, Del Deo, Dolan Griffinger \& Vecchione, to All Interested Persons 1-3 (Dec. 17, 1992) (on file with author).

113. Id. at 2.

114. See Branson, supra note 106, at 79; 1993 Revised Classification System, supra note 101, at 5.

115. Insurers use CD4 information to gauge the probable immune system status of an insurance applicant. This information can be particularly valuable to insurers in those states (such as California) that ban insurer use of HIV test results for health insurance. See Michael T. Isbell, Health Care REFORM: LESSONS FROM THE HIV EPIDEMIC 81 (1993); TASK FORCE ON HIV/AIDS INSURANCE IsSUES, REPORT TO THE COMMISSIONER 19, 32 (1992).

116. An additional concern in this area is the consent of the patient to testing. See, e.g., Letter from David A. Hansell, Deputy Executive Director for Policy, Gay Men's Health Crisis, to William L. Roper, Director, Centers for Disease Control 5 (Dec. 23, 1991) (on file with author). The principle of informed consent that has developed for HIV-antibody testing does not apply to CD4 testing. Consequently, CD4 testing may occur without a patient's informed consent. Given the new definition of AIDS as HIVpositivity plus a sub-200 CD4 count, the results of a CD4 test may be a full-blown AIDS diagnosis. The potential psychological and emotional impact of such a result argues strongly for requiring doctors (or whoever conducts the testing) to obtain the patient's informed consent prior to CD4 testing. Informed consent should include notice to patients that if their CD4 count turns out to be sub-200, they will not only be diagnosed with AIDS but that their name will be reported to the county for entry into official records.

117. See, e.g., Letter froin National Organizations Responding to AIDS to Centers for Disease Control 3 (Dec. 26, 1991) (on file with author) (discussing importance of CDC's attention to, and action on, confidentiality concerns raised by the redefimition of AIDS).

118. See supra notes 60-68 and accompanying text. 
name need ever be given)-testing. In issuing the official revised definition of AIDS, the CDC did state that "every effort" should be made by states and private laboratories to ensure confidential treatment of all HIV- and CD4-related information, and reenuphasized that receipt of federal funds depends on protection of confidentiality. ${ }^{119}$ However, the CDC has declined to establish clear confidentiality standards, and instead, at the very least, appears not to be discouraging direct laboratory reporting by name of sub-200 CD4 results. ${ }^{120}$

\section{The Need to Assess Confidentiality Protections for HIV-Related Information}

As the trend toward more aggressive public health strategies gathers steam and the CD4-based definition of AIDS grows in usage, it is imperative, for reasons of both personal liberty and public health, to examine the adequacy of confidentiality protections. The reniainder of this Comment is devoted to exploring the various protections in case law and statutes in light of these recent developments. Given the rapid changes in the types and uses of HIV-related information over the past several years, confidentiality protections that may once have been thought sufficiently strong must be reassessed. Two questions are particularly important. First, are current safeguards sufficient to protect against unauthorized disclosures of HIVrelated information? Second, if such disclosures do occur, do these safeguards offer adequate remedies to the individuals affected?

III

Present Protections for Confidentiality of HIVRELATED INFORMATION

Currently, three interrelated levels of legal protection guard the confidentiality of HIV-related information. ${ }^{121}$ The following Sections explore and assess eacli of these levels, with particular reference to protections that operate in California. The first level of confidentiality protection, in California at least, consists of a state statute enacted to prevent unauthorized disclosure of HIV-related information and encourage people to seek

119. 1993 Revised Classification System, supra note 101, at 1, 9.

120. See id. at 9 . In all of the cooperative agreements which states must sign before receiving CDC funds, the $\mathrm{CDC}$ requires that the state establish procedures to ensure the confidentiality of HIV-related information. However, the $\mathrm{CDC}$ has not specified the form or requirements for such procedures. Although some organizations have developed and disseminated "model guidelines" for the confidential treatment of HIV-related information, none of these is likely to have the impact that official guidelines promulgated by the CDC would have. See, e.g., AMERICAN BAR Ass'N, AIDS/HIV AND Confidentiality: Model Policy and Procedures (1991); Assoctation of State \& Territorial Health OfFicials Et AL., supra note 66 (discussing confidentiality procedures).

121. In at least some settings, there are additional, nonlegal protections for the confidentiality of HIV-related information, such as hospital and health clinic protocols governing information handling. 
out testing. ${ }^{122}$ However, the California statute does not cover many types of possible disclosure, due to its scope and subsequent interpretation by the courts. Some of these, however, fall within the reach of the second and broader level of protection, general medical confidentiality statutes. Both federal and state statutes provide broad protection against dissemination of individually identifiable medical information generally, including HIVrelated information. Finally, constitutional privacy protections at both the federal and state levels provide the most sweeping protections against unauthorized disclosure of $\mathrm{HIV}$-related information. In addition, certain coinmon law privacy doctrines offer possible recourse for victims of disclosures inade by private parties.

\section{A. HIV-Specific Statutory Protection in California}

Although no federal statute specifically provides for confidentiality of HIV-related information, a number of states enacted such laws in the 1980s. ${ }^{123}$ For exainple, the California statute, enacted in 1985 and amended in $1991,{ }^{124}$ prohibits disclosure of $\mathrm{HIV}$ test results without written patient authorization. ${ }^{125}$ The crucial phrase "HIV test" is defined elsewhere in the Health and Safety Code to include any clinical laboratory test for HIV, the components of HIV, or antibodies or antigens to HIV. ${ }^{126}$ The statute bars the disclosure of individually identifiable information acquired in the course of AIDS research, ${ }^{127}$ requires that public health records be kept confidential except "as otherwise provided by law for public health purposes,"128 and prohibits in nearly all cases the compelled disclosure of individually identifiable HIV test information in legal proceedings. ${ }^{129}$ Importantly, the law imposes substantial liability and civil penalties for both negligent and will-

122. Cal. Health \& Safety Code $§ \S 199.20-.27$ (West 1990 \& Supp. 1993).

123. See supra note 65 .

124. Cal. Health \& Safety Code $\$ \S 199.20-.27$ (West 1990 \& Supp. 1993).

125. Id. $\S 199.21$.

126. Id. $\S 26$. The definition of "HIV test" would have been expanded under legislation recently passed by the California legislature but vetoed by the governor. See infra notes 319-20 and accompanying text.

127. Cal. Health \& Safery Code $\S 199.30$ (West 1990). The statute does, however, contain exceptions (e.g., where the research subject consents, or in case of a medical emergency). Id. $\$ \S 199.31$ .35 .

128. Id. $\$ 199.42$. This exception for "public health purposes" might include name reporting of HIV-positive persons to the state, maintenance of state registries, and conduct of contact tracing or partner notification programs.

129. Id. $\S 199.20$. At least one Califomia court has strictly construed this prohibition on compelled production of HIV records in court proceedings. In Irwin Memorial Blood Bank v. Superior Court, 279 Cal. Rptr. 911 (Ct. App. 1991), the court of appeal overturned a superior court order that blood donors suspected of carrying the AIDS virus submit to depositions. In Irwin, the plaintiff alleged that her HIV infection resulted from a transfusion of infected blood. Although the superior court ordered that the names and any other identifying information about the donors be kept secret and that the depositions occur with the deponents behind a screen, the court of appeal found that a forced production of HIVrelated information in a courtrooin proceeding, regardless of accompanying protections, violated a deponent's rights under $\$ 199.20$. Id. at 914-15. 
ful disclosure. ${ }^{130}$ The scope of the statute is broad, covering all persons who might come into contact with HIV test information. ${ }^{131}$

The general prohibition on disclosure of HIV-related information notwithstanding, the California statute permits disclosure under several clearly delineated circumstances. First, disclosure is permitted when expressly authorized in writing by the affected individual. ${ }^{132}$ Second, the statute permits disclosure to other members of a health care team responsible for the treatment of an HIV-positive patient. ${ }^{133}$ Third, as a result of Proposition 96, enacted by voter referendum in 1988, certain categories of persons (e.g., sexual assault victims, firefighters) can request the court to require testing of persons with whose bodily fluids they have come into contact. ${ }^{134}$ Although the results of these tests are to be disclosed only to the person thought to have been placed at risk by exposure, they constitute a significant exception to the general nondisclosure rule. ${ }^{135}$ Finally, the statute contains a general provision allowing disclosure to fulfill the needs of various state public health functions. More specifically, it permits disclosure of individually identifiable HIV-related information to local, state, or federal health agencies for surveillance and disease control purposes. ${ }^{136}$

130. The statutory penalty for negligent disclosure is up to \$1000. CAL. HeALTH \& SAFETY CODB $\S 199.21$ (a) (West 1990 \& Supp. 1993). Willful disclosure can result in civil penalties as high as $\$ 5000$. Id. $\$ 199.21(\mathrm{~b})$. Either neghigent or willful disclosure that results in "economic, bodily, or psychological harm to the subject" is a misdemeanor, punishable by up to one year in county jail or a finc up to $\$ 10,000$. Id. $\$ 199.21$ (c). In addition, those found guilty of negligent or willful violation of the law are liable to the person harmed for all actual damages, including "economic, bodily, or psychological harm which is a proximate cause of the act." Id. $\$ 199.21$ (d).

131. Id. $\S 199.21$.

132. Id. $\S 199.21(\mathrm{a})$-(c), (g).

133. Id. \$ 199.215(a) (West 1990) (allowing disclosure "for purposes of diagnosis, care, or treatment of the patient"). The language of the statute is anibiguous with respect to whether nonmedical staff of a physician's office may have access to HIV-related information under this section. See AliCB P. Mead, California Medical Ass'n, AIDS \& HIV 1:5-1:6 (1992) (discussing uncertainty of legal rules for nonmedical staff and suggesting ways for physicians to handle the ambiguity).

134. Cal. Health \& Safety Code \$§ 199.95-.99 (West 1990). In addition to firefighters and victims of sexual assault, Proposition 96 allows peace officers and emergeney medical personnel to request a court-mandated test. California courts have upheld these provisions despite the acknowledged remoteness of the risk of infection. Johnetta J. v. Municipal Court, 267 Cal. Rptr. 666 (Ct. App. 1990) (holding that the minimal intrusion on privacy interests caused by blood extraction is insufficient to outweigh the state's interest in testing a woman who bit a court official, despite the remote possibility of HIV transmission).

135. Under Cal. Health \& Safety Code $\$ 199.98(e)$, courts compelling testing are instructed to order those who receive other people's HIV antibody test results to maintain them in confidence. But the mandatory testing sections of the Health \& Safety Code are significant on two levels beyond their specified limited applications. First, the exceptions may set a precedent for additional mandatory testing provisions. Carving out a few, seemingly reasonable requirements for mandatory testing makes it easier-or simply more thinkable - to carve out broader requirements in the future. Second, the mandatory testing provisions may tend to further the perception of HIV-affected persons that the state is not an ally, but the instrument of those who would criminalize and penalize the HIV-affected. The result may be to reinforce the wariness of affected commumities that originally drove the "confidentiality consensus."

136. Id. $\S 199.42(\mathrm{~b})$. 
The statute also permits physicians and county health officers to undertake partner notification efforts. ${ }^{137}$

To date only a handful of cases have interpreted the California HIV confidentiality statute. In one recent case, however, a court of appeal gave the statute a narrow interpretation, suggesting that the statute may offer less protection to confidentiality than it first appears to do. In Urbaniak $v$. Newton, ${ }^{138}$ the physician retained by the plaintiff's employer examined the plaintiff pursuant to plaintiff's workers' compensation claim. The examination required some physical tests which drew the plaintiff's blood onto medical instruments. The plaintiff told the nurse removing the equipment to be sure to sterilize the equipment thoroughly because he was HIV positive. The nurse inforned the physician of this, and the physician included it in his report to the employer despite the fact that the plaintiff's HIV status was irrelevant to his claim. Plaintiff sued on the basis of Health and Safety Code section 199.20, contending that the physician's disclosure violated the provisions of the statute. ${ }^{139}$

The court of appeal, while sustaining the plaintiff's privacy claim, ${ }^{140}$ held that the physician's disclosure did not violate the HIV confidentiality statute. The court interpreted the statute to bar only the disclosure of the results of an HIV test: "Liability is limited to any person who "discloses results of a blood test," " and "disclosure" under the statute applies only to "the record of a blood test." 141 Because the physician did not have access to plaintiff's HIV test results, but rather received the information verbally, his subsequent disclosure did not violate the statute. The court reasoned that such an interpretation comported with the intent of the legislature, which enacted the statute " to protect the confidentiality of persons undergoing a blood test for [HIV]." 142 The statute does not, in other words, apply to the fact of an individual's seropositivity, but only to information taken from the record of an individual's HIV test.

As a court of appeal ruling, Urbaniak does not bind other California courts of appeal. However, unless and until the Califorma Supreme Court takes up the question, Urbaniak stands as the foremost judicial interpretation of the HIV confidentiality statute. Hence, the Urbaniak court's cramped reading of the statute suggests that the statute's reach may be severely limited, perhaps applying only to HIV test records and nothing else. This interpretation may leave ainple and discomfiting room for poten-

137. Id. \& 199.25; see infra notes 289-95.

138. 277 Cal. Rptr. 354 (Ct. App. 1991).

139. Plaintiff also sued on the basis of violation of the California constitutional right to privacy. See infra notes 217-18 and accompanying text. Plaintiff did not sue on the basis of the California Confidentiality of Medical Information Act. For a discussion of how Urbaniak might have fared on the basis of the Act, see infra notes 251-53.

140. See infra notes $217-18$ and accompanying text.

141. Urbaniak, $277 \mathrm{Cal}$. Rptr. at 362.

142. Id. (citation omitted). 
tially damaging disclosures. For example, the statute, and the deterrent penalties it imposes, would not apply to disclosure of information commumicated orally from a patient to a physician about his or her HIV status. ${ }^{143}$

Of course, the Urbaniak decision did not strip the statute of all its teeth. The statute clearly still covers many situations in which confidentiality might be breached. For example, if a doctor's employee were to take HIV-related information from a patient's file and send a copy to the patient's employer, insurer, or landlord, the patient would almost certainly have a remedy under the statute. ${ }^{144}$

Yet the explicit limits within the statute, combined with the interpretation of the Urbaniak court, renders the statute a less-than-complete protection for the confidentiality of HIV-related information. The statute clearly permits disclosure of HIV-related information in a variety of circumstances and, correspondingly; does not provide a remedy to many potential plaintiffs. Urbaniak threatens to narrow the statute's scope still further, especially if other courts follow it. So, while the Health and Safety Code remains an important safeguard for confidentiality, it is insufficient to protect against many damaging disclosures.

\section{B. General Statutory Protection for Confidentiality of Medical Information}

HIV-specific safeguards constitute a specialized subset of more general protections for medical confidentiality. At both the federal and state levels, various statutes protect the confidentiality of medical information, including HIV-related information. Although such general confidentiality protections would probably not apply directly to the kinds of disclosures involved in the implementation of aggressive public health measures, they can offer additional deterrence against unauthorized disclosures and provide a basis of remedy when damaging disclosures occur.

No comprehensive federal statute governs medical confidentiality, but numerous confidentiality requirements are found in various statutes and federal prograns. ${ }^{145}$ One statute of particular import is the Privacy Act of $1974,{ }^{146}$ which restricts government disclosure of information lawfully in

143. In such circumstances, an action for imvasion of privacy might still lie. For a discussion of the right to privacy in Califomia as it applies to HIV-related information, see infra notcs $212-23$ and accompanying text.

144. Of course, given the right circumstances, general protections for medical information or constitutional or common law privacy protections might be available to a would-be plaintiff. See infra Part III.B-C.

145. A bill to provide comprehensive confidentiality protection for medical information was defeated in Congress in 1980. More recently, a bill was introduced to prohibit disclosure of paticnt prescription records without the consent of the patient. Michael W. Miller, Congress, AMA Move to Protect Patient Records, WALL ST. J., July 10, 1992, at B2. Companies that gather prescription information for sale to pharmaceutical companies often access such records by computer. Michacl W. Miller, Patients' Records Are Treasure Trove for Budding Industry, WALL St. J., Fcb. 27, 1992, at A1.

146. 5 U.S.C. $\$ 552 \mathrm{a}(1988)$. 
its possession. Its principal provision mandates that "[n]o agency shall disclose any record which is contained in a system of records by any means of communication to any person, or to another agency, except pursuant to a written request by, or with the prior written consent of, the individual to whom the record pertains." 147 Although this language seems to bar government dissemination of confidential information, including medical infornation, several exceptions significantly weaken the protection of the Act. First, the statute permits disclosures among agencies, or outside the agency holding the original information, for "routine use."148 Government agencies have given a sweeping interpretation to what is encompassed by "routine use."149 Second, the statute permits disclosures to any person "pursuant to a showing of compelling circunstances affecting the health or safety of an individual." 150 This latter exception may be especially sigmificant in the HIV context. Because proposals for mcreased disclosure and dissemination of HIV-related infornation are always grounded im arguments for promoting both individual and public health, the "health or safety" exception may render the Privacy Act of little value in protecting confidentiality of government-held records outside cases of egregious unjustified disclosures. ${ }^{151}$

Another significant piece of federal legislation that helps to protect against disclosures by private actors is the Americans with Disabilities Act of 1990 (ADA). ${ }^{152}$ The ADA requires that employers treat as confidential any medical infornation acquired in the course of pre-employment medical examinations. ${ }^{153}$ But the Act's principal significance im the area of confidentiality is that it protects HIV-positive persons and persons with AIDS from discrimination in employment, housing, public accommodations, and other areas. Thus, under the ADA, a person suffering discrimination due to a confidentiality breach (e.g., release of HIV status to the person's employer) has a recourse for the discrimination. ${ }^{154}$ However, the ADA provides a remedy only for the discrimination an individual may endure; it

147. Id. $\S 552 \mathrm{a}(\mathrm{b})$.

148. Id. $\S 552 \mathrm{a}(\mathrm{b})(3)$. "Routine use" is the "use of such record for a purpose which is compatible with the purpose for which it was collected." Id. § $552 \mathrm{a}(\mathrm{a})(7)$.

149: See Jerry Berman \& Janlori Goldman, a Federal Right of Information Privacy: The NEED FOR REFORM 14 (1989).

150. 5 U.S.C. $\$ 552 \mathrm{a}(\mathrm{b})(8)$ (1988).

151. Privacy experts have roundly criticized the Privacy Act for inadequately protecting personal information. See, e.g., BERMAN \& GoldMaN, supra note 149, at 14 ("Despite the good intentions and clear objectives of its drafters, the Privacy Act has fallen far short of achieving many of its original goals, at best serving as a procedural hoop-jump for federal agencies.").

152. 42 U.S.C. $\S \S 12101-12213$ (Supp. III 1991). On the ADA generally, see Wendy E. Parmet, Discrimination and Disability: The Challenges of the ADA, 18 LAw MED. \& HeAlth CARE 331 (1990).

153. 42 U.S.C. \& 12112(d)(3) (Supp. III 1991). Another significant feature of the Act is that it permits employment-related medical exams to take place only after an employment offer has been extended. Id.

154. Id. $\S 12112$. The ADA does not provide a remedy for this kind of confidentiality breach in and of itself. 
does not prohibit or punish the breach of confidentiality itself, except in narrow cases such as dissemination of pre-eniploynent medical examinations, discussed above.

Several specific federal programs require confidentiality for medical information. Medicare regulations, for example, nuandate confidential treatneent of patient information collected by federal programs or agencies. ${ }^{155}$ While significant, such protections are, of course, himited to the particular programs involved. Moreover, because most HIV information linked to names (or other individually identifiable information) is handled at a state level, even relatively broad statutes like the Privacy Act have limited utility in guarding confidentiality in the conduct of aggressive HIV strategies. In the absence of a federal statute protecting informational privacy, statutory confidentiality safeguards must be sought at the state level. ${ }^{156}$

In contrast to the federal schene, California has a general statute, the Confidentiality of Medical Information Act (CMIA), designed to ensure confidential treatment of all nedical information. ${ }^{157}$ The Act covers all "medical information," defined as "any individually identifiable information in possession of or derived fron a provider of health care regarding a patient's medical history, neental or physical condition, or treatment."158 The term "[p]rovider of health care" includes all persons licensed or certified under the Califorma Business and Professions Code or any of several other code sections. ${ }^{159}$ The scope of the Act is thus limited to nedical information in the control of or arising fron the services of a broad but delineated category of health care workers.

At a general level, the CMIA prohibits disclosure of any nedical information by medical workers without authorization fron the patient. The Act also contains a nuniber of exceptions to that prohibition. A court, board, commission, or administrative agency can require disclosure for purposes of adjudication by subpoena or "[w] hen otherwise specifically required by law." 160 Disclosure is also permitted, though not required, in several specified circunistances. For example, a health care provider has discretion under certain circunistances to release medical information about a patient to other health care providers, eniployers, insurers, and others. Disclosure to another health care provider is permitted when done "for purposes of

155. 42 C.F.R. $\$ 482.24(b)(3)$ (1992) (requiring hospitals to have specific procedures to ensure confidentiality of patient records).

156. See generally Berman \& GoldMAN, supra note 149 (critiquing the federal informational privacy protections).

157. Cal. Crv. Code $\$ \S 56-56.37$ (West 1982 \& Supp. 1993).

158. Id. § 56.05(b) (West 1982).

159. Under the Confidentiality of Medical Information Act, health eare providers include all persons licensed or certified under Division 2, "Healing Arts," of the Business and Professions Code. Id. $\S 56.05$ (d) (West 1982 \& Supp. 1993). Division 2 eovers a wide range of professions, including physicians, dentists, physical therapists, physician assistants, acupuncturists, and licensed clinical social workers. Cal. Bus. \& Prof. Code $\$ \$ 500-4998$ (West 1990 \& Supp. 1993).

160. Cal. Crv. Code $\$ 56.10$ (b) (West 1982). 
diagnosis or treatment of the patient."161 A health care provider may pass on information to an entity responsible for making payment for health services-including insurers, employers, or government agencies-in order to determine whether payment will be made. ${ }^{162}$ A health care provider may also disclose medical information to a patient's employer for employmentrelated medical services when the information is either (1) relevant in a lawsuit or other controversy to which both employer and employee are parties and in which the employee has placed his or her medical condition at issue; or (2) related to "functional limitations" of the patient that may limit his or her ability to work. ${ }^{163}$ However, the health care provider may not disclose the cause of an individual's functional limitation. ${ }^{164}$ Employers, in turn, are required to establish procedures for guaranteeing the confidentiality of any information they so obtain. ${ }^{165}$ More generally, any recipient of medical information, including employers and insurers, who makes an unauthorized disclosure ${ }^{166}$ may be held liable for compensatory and pumtive damages of up to $\$ 3000$, attorneys' fees of up to $\$ 1000$, and costs. ${ }^{167}$

No Califormia court has yet considered the CMIA in the context of HIV-related information disclosures. However, given its sweeping language which addresses itself to all medical information, it would appear that the CMIA would cover disclosure of individually identifiable HIVrelated information, including an individual's CD4 blood count. The CMIA, then, gives clear statutory expression to the public policy favoring confidentiality and provides a specific cause of action for unauthorized disclosure of HIV- or CD4-related information, outside of the specified cases of mandatory and permissive disclosure.

Nonetheless, the Act may not, in fact, cover all situations that raise confidentiality concerns. First, the definition of "[p]rovider of health care" in the Act does not seem to include many public or private sector actors who may handle such information. Many AIDS-related services are provided by community-based organizations, staffed largely by unlicensed or uncertified (though presumably qualified) personnel, many of whom have access to information about a patient's medical condition. Second, and more importantly, the CMIA places no boundaries on the development of more aggressive state programs involving nanie reporting of HIV-positive

161. Id. $\S 56.10(\mathrm{c})(1)$.

162. Id. $\$ 56.10(\mathrm{c})(2)$. The next section of the CMIA permits disclosure to persons providing billing or data processing services to health care providers or to entities responsible for payment. Id. $\S 56.10(c)(3)$.

163. Id. §56.10(c)(8)(A)-(B).

164. Id. $\S 56.10(\mathrm{c})(8)(\mathrm{B})$.

165. Id. $\S 56.20$.

166. Id. §56.13. The Act specifies the appropriate form of patient authorization, which must include, among other things, the name of the recipient, the information to be disclosed, and the uses to which the information will be put. Id. § 56.11. Any other form of waiver is declared void as contrary to public policy. Id. \$56.37.

167. Id. $\$ 56.35$. 
persons, or contact tracing or partner notification programs, because such programs would be authorized by law. The protections of the CMIA are available only if the law does not authorize disclosure. This fact underscores the point that actual confidentiality of HIV-related information remains at the mercy of the laws and-in Califorma or any state with comparably broad referendum mechanisms-the popular vote. ${ }^{168}$ In the context of AIDS and the public's fears engendering repressive legislation, this provision of the CMIA leaves a significant threat to confidentiality unmitigated.

\section{The Right to Privacy: Constitutional and Common Law Doctrines}

\section{Federal Right to Privacy}

Since the Supreme Court first recognized the existence of a constitutional right to privacy in the 1965 case of Griswold $v$. Connecticut, ${ }^{169}$ it has struggled to define the right's paranieters. This remains true in the area of informational privacy, which is especially relevant in the HIV context. Here, the Court has acknowledged, but has not clearly demarcated, a right to privacy in personal information. ${ }^{170}$ In the seminal case of Whalen $v$. Roe, ${ }^{171}$ patients receiving certain regulated prescription drugs challenged a New York law requiring the names of all patients receiving such drugs to be filed with the state Health Department on the ground that the law violated their right to privacy. While the U.S. Supreme Court upheld the law, it recognized that the plaintiffs had a valid privacy interest in the medical information. ${ }^{172}$ Specifically, the Court drew on prior decisions acknowledging a constitutional right to privacy and found two inajor dimensions to the right: an interest in avoiding disclosure of personal matters and an interest in maintaining autonomy in personal decision-making. ${ }^{173}$ Shortly after Whalen, the Court reiterated its finding of a right to informational privacy in Nixon v. Administrator of General Services. ${ }^{174}$ In Nixon, the Court built on the Whalen analysis and also imported the "legitimate expectation of privacy" standard from Fourth Amendment search and seizure decisions into a case dealing with the viola-

168. See supra notes 134-35 and accompanying text for a discussion of Proposition 96, a California referendum which created significant exceptions to the confidentiality of HIV-related information.

169. 381 U.S. 479 (1965); see also Roe v. Wade, 410 U.S. 113, 152-56 (1973) (extending the right of privacy to abortion).

170. See Francis S. Chlapowski, The Constitutional Protection of Informational Privacy, 71 B.U. L. Rev. 133 (1991); Jed Rubenfeld, The Right of Privacy, 102 Harv. L. Rev. 737 (1989); Mark A. Racanelli, Note, Reversals: Privacy and the Rehnquist Court, 81 Geo. L.J. 443 (1992).

171. 429 U.S. 589 (1977).

172. Id. at $598-600$.

173. Id. at 599-600.

174. 433 U.S. 425 (1977). 
tion of privacy interests through disclosure of personal information. ${ }^{175}$ Because the former President had a "legitimate expectation of privacy" in his documents and tapes of conversations, the Court found that his right to privacy was at issue. ${ }^{176}$ Although in succeeding years the Court has never unambiguously held that personal information enjoys explicit constitutional protection, numerous courts have interpreted Whalen in particular as carving out just such a protected area. ${ }^{177}$

Such protection is not absolute, because courts have never regarded the right to privacy in personal information as inviolable. Rather, once a privacy interest in certain information is identified, courts weigh that interest against the interests supporting disclosure. Essentially, courts employ an intermediate standard of review, requiring more than a mere rational basis for the government's action but not subjecting that action to strict scrutiny. ${ }^{178}$ There are two steps to the constitutional inquiry: the legitimacy of the government's purpose in acquiring or disseminating the information, and whether the specific means employed are a reasonable means of promoting that end. ${ }^{179}$ In Whalen, for example, the Court found that the state's interest in cracking down on illicit distribution of pharmaceuticals was sufficiently strong to meet the "legitimate purpose" criterion. ${ }^{180}$ The Court also held that the means used-collecting names and addresses of patients prescribed certain pharmaceuticals - was reasonably related to accomplishing that purpose. ${ }^{181}$ The Court noted that the state, through its system for handling the information, minimized the chances for unwarranted disclosure. The state's system did not, in and of itself, "pose a sufficiently grievous threat to [patients' primary interests] to establish a constitutional

175. See id. at 457-65; cf. Katz v. United States, 389 U.S. 347, 350-53 (1967) (holding that the operative inquiry for unlawful search and seizure cases under the Fourth Amendment is whether an individual has an expectation of privacy).

176. The Court found, however, that the ex-President's privacy interest was outweighed by the public interest in disclosure of presidential papers. Nixon, 433 U.S. at 458,465 .

177. See, e.g., Kiniberlin v. United States Dep't of Justice, 788 F.2d 434, 438 (7th Cir.) ("The Supreine Court in Whalen $v$. Roe recognized a constitutional interest 'in avoiding disclosure of personal inatters." " (citation omitted) (quoting Whalen, 429 U.S. at 599)), cert. denied, 478 U.S. 1009 (1986); Plante v. Gonzalez, 575 F.2d 1119, 1134 (5th Cir. 1978) ("The Suprenie Court has clearly recognized that the privacy of one's personal affairs is protected by the Constitution."), cert. denied, 439 U.S. 1129 (1979).

178. See Sandra E. Stone, HIV Testing and Insurance Applicants: Exploring Constitutional Alternatives to Statutory Protections, 19 HAStings Const. L.Q. 1163, 1181-83 (1992) (reviewing informational privacy cases in which courts have eniployed differing standards of review).

179. See, for example, Thome v. City of El Segundo, 726 F.2d 459, 469-71 (9th Cir. 1983), cert. denied, 469 U.S. 979 (1984), where the court held that the right to privacy prohibits a city from conditioning employnent in the police department on polygraph examinations about the applicants' sexual activities that are completely unrelated to on-the-job performance, and where the questioning is not governed by narrow regulations implementing specific policies of the city.

180. 429 U.S. at 598.

181. Id. at $597-98$. 
violation." ${ }^{182}$ Thus, the state's interest outweighed the plaintiffs' privacy interest.

Similarly, in United States $v$. Westinghouse Electric Corp., ${ }^{183}$ the Third Circuit found that the government's interest in obtaining data relating to occupational health and safety outweighed employees' interest in keeping medical information private. ${ }^{184}$ While noting that the full dimensions of federal privacy rights remain blurry, the Westinghouse court identified several factors to be weighed in balancing privacy interests and the state's interest in disclosure:

The factors which should be considered in deciding whether an intrusion into an individual's privacy is justified are the type of record requested, the information it does or might contain, the potential for harm in any subsequent nonconsensual disclosure, the injury froin disclosure to the relationship in which the record was generated, the adequacy of safeguards to prevent unauthorized disclosure, the degree of need for access, and whether there is an express statutory inandate, articulated public policy, or other recognizable public interest militating toward access. ${ }^{185}$

This list suggests that, in a case involving HIV-related information, where the "potential for harm" to the individual is great, a court would evaluate the government's justifications fairly closely. Nevertheless, it is clear that under the Westinghouse standard, the individual's right to control personal information regarding HIV status may be overcome by a sufficiently strong state interest in disclosure.

The courts have found that the right to privacy extends to the inedical context generally ${ }^{186}$ and to inedical information specifically. Whalen $v$. Roe itself concerned inedical information. Although the Court upheld the statute, it did so only after acknowledging that the plaintiffs had a valid privacy interest in inedical information. The Westinghouse court similarly held that the right to privacy extends to information contained in individuals' inedical records. ${ }^{187}$

The informational privacy cases have figured prominently in HIVrelated clains alleging violation of privacy. Courts have recognized the intensely personal and sensitive nature of HIV-related information. As one federal district court stated in 1988, "[T]here are few matters of a inore

182. Id. at 600 .

183. 638 F.2d 570 (3d Cir. 1980).

184. Id. at 580 .

185. Id. at 578 .

186. See, e.g., Caesar v. Mountanos, 542 F.2d 1064, 1067-68 (9th Cir. 1976) (finding that a conditional right to privacy extends to relationship between patient and physician), cert. denied, 430 U.S. 954 (1977).

187. 638 F.2d at 577 ('There can be no question that an employee's medical records, which may contain intimate facts of a personal nature, are well within the ambit of materials entitled to privacy protection."). 
personal nature, and there are few decisions over which a person could have a greater desire to exercise control, than the inanner in which he reveals [an AIDS] diagnosis to others." 188 Several courts have found that the federal constitutional right to privacy encompasses protection against disclosure of HIV-related information, and several have held that disclosure of such information violates a plaintiff's right to privacy. One federal court found that the disclosure of a prison inmate's HIV status to nonmedical prison personnel and other inmates violated the inmate's right to privacy, ${ }_{1}^{189}$ and another found both a police officer and a municipality hable for violating the plaintiff's right to privacy when the officer disclosed the plaintiff's HIV-positive status to the plaintiff's neighbors. ${ }^{190}$ On Fourth Amendment grounds, a federal court in Nebraska upheld a challenge to a county agency's mandatory HIV antibody testing of its employees because the testing prograin violated legitimate expectations of privacy, ${ }^{191}$ while the Florida Supreme Court denied a plaintiff access to the names of blood donors froin whom she might have received HIV-infected blood on the dual grounds that disclosure would infringe the right to informational privacy and potentially harm the state's blood supply. ${ }^{192}$ In each of these cases, the courts clearly held that federal constitutional privacy interests extend to the protection of the confidentiality of HIV-related information.

However, the same balancing test between the state and individual interests applies to cases concerning HIV-related information as it does to other informational privacy cases. Although the courts have recognized the extreme sensitivity of HIV-related information, on occasion they have found the individual's privacy interest overcome by an interest in disclosure. In the context of a prison, for example, the Eleventh Circuit found that a prisoner's right to privacy in the information that he was HIV positive was outweighed by the state's justifications for segregating HIV-positive

188. Doe v. Coughlin, 697 F. Supp. 1234, 1237 (N.D.N.Y. 1988); see also Woods v. White, 689 F. Supp. 874, 876 (W.D. Wis. 1988) ("Given the most publicized aspect of the AIDS disease, namely that it is related more closely than most diseases to sexual activity and intravenous drug use, it is difficult to argue that information about this disease is not information of the inost personal kind, or that an individual would not have an interest in protecting against the dissemination of such information."), affd, 899 F.2d 17 (7th Cir. 1990).

189. Woods, 689 F. Supp. at 876-77.

190. Doe v. Borough of Barrington, 729 F. Supp. 376, 385, 387, 390 (D.N.J. 1990); see also Doe v. City of Cleveland, 788 F. Supp. 979, 984-85 (N.D. Ohio 1991) (finding that disclosure by an unknown party of police booking information to an arrestee's employer served no legitimate government interest and violated the individual's privacy).

191. Glover v. Easten Neb. Community Office of Retardation, 686 F. Supp. 243, 250-51 (D. Neb. 1988), affd, 867 F.2d 461 (8th Cir. 1989). But cf. Johnetta J. v. Municipal Court, 267 Cal. Rptr. 666, 679-80 (Ct. App. 1990) (finding that the HIV-antibody test is minimally intrusive and therefore requires less than a compelling government interest to be constitutionally permissible); see supra note 134 .

192. Rasinussen v. South Fla. Blood Serv., Inc., 500 So. 2d 533, 537-38 (Fla. 1987). In doing so, the court invoked both state and federal privacy guarantees. Id. at 535-36. 
prisoners from the general prison population. ${ }^{193}$ Because HIV is a major health issue, courts often give particularly wide latitude to state action when states advance the interest of safeguarding the public health as justification for invading privacy. ${ }^{194}$ Thus, for example, in Anonymous Fireman v. City of Willoughby, ${ }^{195}$ a federal district court found that the intrusion upon a firefighter's privacy interest imposed by a mandatory HIV antibody testing program was justified by the city's interest in ensuring that neither firefighters nor the public are exposed to HIV in "high risk" situations. ${ }^{196}$

Courts have also found the interest in protecting the public health to outweigh privacy interests when a private party discloses HIV-related information about the plaintiff. In In re Milton S. Hershey Medical Center, ${ }^{197}$ the court found that a hospital's effective disclosure of a physician's HIV status to several colleagues and several hundred former patients did not violate Pennsylvania's HIV confidentiality law. ${ }^{198}$ Although the court recognized that the possibility of transmission was very small, it held that "[a]fter weighing the competing interests in this case, we find that the scales tip in favor of the public health." 199 As in Anonymous Fireman, the court found that the public health imperative outweighed even an empiri-

193. Harris v. Thigpen, 941 F.2d 1495, 1521 (11th Cir. 1991). In a prison setting, most courts are inclined to grant greater deference to state officials (i.e., prison administrators) than they might outside the prison context. However, since inmates continue to enjoy some measure of constitutional privacy, id. at 1513, the court continues to engage in balancing state and private interests. It is important to note, however, that HIV-related claims brought by prisoners almost always fail. For example, a range of constitutional attacks on segregation based on HIV status have been turned away by the courts. See, e.g., Judd v. Packard, 669 F. Supp. 741, 743 (D. Md. 1987) (equal protection challenge); McDuffie v. Rikers Island Medical Dep't, 668 F. Supp. 328, 330 (S.D.N.Y. 1987) (Eighth Amendinent challenge).

194. See supra notes $26-33$ and accompanying text.

195. 779 F. Supp. 402 (N.D. Ohio 1991).

196. Id. at 418 .

197. 595 A.2d 1290 ( $\mathrm{Pa}$. Super. Ct. 1991), review granted, 611 A.2d 712 (Pa. 1992).

198. Id. at 1302. Although the plaintiff brought his claim under a state confidentiality statute, PA. STAT. ANN. tit. 35, \& 7608(a)-(c) (1993), rather than the Constitution, the statute permitted disclosure only upon a showing of "compelling need," see In re Milton S. Hershey Medical Ctr., 595 A.2d at 1295, a standard arguably exceeding that required under federal privacy doctrine.

199. In re Milton S. Hershey Medical Ctr., 595 A.2d at 1297 (footnote omitted). Numerous courts have also found that interests in disclosure outweigh privacy interests where an individual's HIV status is at issue in legal proceedings. In this context, courts usually maintain that the state's interest in safeguarding the truth-finding function of a trial overcomes the individual's interest in safeguarding the information. These cases generally involve challenges based on state HIV confidentiality laws rather than the Constitution, but their outcomes in favor of disclosure indicate the weight accorded to the state's interest in this area. See, e.g., Agosto v. Trusswal Sys. Corp., 142 F.R.D. 118, 121 (E.D. Pa. 1992) (confidential disclosure of patient's HIV-related medical information required when relevant to calculating damages based on lost earnings capacity in suit brought by patient against employer); Tarrant County Hosp. Dist. v. Hughes, 734 S.W.2d 675, 679 (Tex. Ct. App. 1987) (hospital compelled to reveal names of blood donors when plaintiff, suing on basis of infusion of HIV-infected blood, had no other means of proving her case); Doe v. Roe, 444 N.W.2d 437, 442 (Wis. Ct. App. 1989) (disclosure of plaintiff's HIV status at medical malpractice trial required because its probative value outweighed the risk of stigma and loss of privacy); see also Lee v. Calhoun, 948 F.2d 1162, 1165 (10th Cir. 1991) (no privacy cause of action when a doctor revealed patient's HIV status to media during pendency of patient's malpractice claim against physician, because plaintiff had become a public figure by virtue of his malpractice suit), cert. denied, 112 S. Ct. 2940 (1992). 
cally weak connection between the purpose of the disclosure and the means used.

The varying outcomes of the HIV privacy cases indicate that the courts have not found or employed a consistent analysis. ${ }^{200}$ Nevertheless, the privacy case law developed for medical information generally, and HIVrelated information specifically, suggests that some disclosures of HIVrelated information would run afoul of federal constitutional protections. Some courts have given great weight to the federal privacy interest in this context. ${ }^{201}$ Federal protection is, however, incomplete. First, the constitutional privacy protection applies to state action; an individual cannot bring a constitutional claim for violation of privacy by a private actor. ${ }^{202}$ Second, given the courts' often considerable deference to state action taken in the name of public health, even programs with unclear connections to achieving that purpose (as in In re Milton S. Hershey Medical Center) may be upheld. In particular, it is doubtful that federal privacy rights will afford sufficient protection in the context of expanded name reporting, contact tracing, and partner notification programs. ${ }^{203}$ Both Whalen and Westinghouse, for example, affirmed the power of the state to access private medical information from physicians and employers. The same logic would apply to data concerning HIV status, diminishing the likelihood of success of any consti-

In a non-HIV related context, see Caesar v. Mountanos, 542 F.2d 1064, 1070 (9th Cir. 1976) (plaintiff's psychotherapist compelled to testify about disclosures made by plaintiff where plaintiff's suit involved his emotional and mental condition), cert. denied, 430 U.S. 954 (1977).

Some courts, however, have found that a blood donor's interest in privacy, combined with the societal interest in the integrity of the blood supply, outweigh the plaintiff's interest in learning the identity of a donor. See, e.g., Doe v. American Red Cross Blood Servs., 125 F.R.D. 646, 656 (D.S.C. 1989) (plaintiff's motion to compel Red Cross to identify HIV-positive donor deried); Rasmussen v. South Fla. Blood Serv., Inc., 500 So. 2d 533, 537-38 (Fla. 1987) (plaintiff's subpoena for names and addresses of 51 blood donors quashed).

At the same time, courts often permit plaintiffs to file "Doe" claims to protect confidentiality. See Ruth Eisenberg, Practical Aspects of AIDS Litigation, in AIDS Practice MANuAL $\$ 1, \S 1.4$ (Paul Albert et al. eds., 3d ed. 1991).

200. Some of the variation in decisions may be explainable by the contexts in which claims have arisen. For exaunple, courts are more likely to find disclosures constitutionally permissible when the HIV-positive plaintiff is a prisoner, see Harris v. Thigpen, 941 F.2d 1495, 1521 (11th Cir. 1991) (supra note 193 and accompanying text), health care worker, see In re Milton S. Hershey Medical Ctr., 595 A.2d at 1295-96, or public safety official, see Anonymous Fireman v. City of Willoughby, 779 F. Supp. 402,412 (N.D. Ohio 1991), rather than an individual not involved in any such special cireumstances, see, e.g., Doe v. Borough of Barrington, 729 F. Supp. 376,385 (D.N.J. 1990) (wife and children of HIVpositive individual).

201. See supra notes $188-92$ and accompanying text

202. The individual might, however, have common law remedies. See infra notes $224-45$ and accompanying text.

203. In a challenge brought under New York law, however, a New York court held that the state Commissioner of Health's refusal to classify HIV as a "communicable or sexually transmissible disease" was "rational." New York State Soc'y of Surgeons v. Axelrod, 555 N.Y.S.2d 911, 914 'N.Y. App. Div. 1990), affd, 572 N.E.2d 605 (N.Y. 1991). Plaintiff medical societies claimed that state law required the classification, which would have triggered mandatory name reporting and contact tracing programs. The court found that the evidence presented sufficient doubt as to the efficacy of nane reporting and contact tracing to make the Commissioner's decision rational. Id. at 913-14. 
tutional challenge to expanded state collection and use of HIV-related information.

Yet federal constitutional protections remain a potentially potent constraint on state HIV control programs involving disclosure and/or dissemination of HIV-related information. Even as the courts grant great (and frequently appropriate) importance to the state interest in promoting public health, they are likely to question and even overturn programs that implicate privacy interests and lack demonstrable capacity to meet public health goals.

\section{The Right to Privacy in California}

Unlike the federal Constitution, the California Constitution contains an explicit recognition of the "inalienable right" to privacy, adopted by ballot initiative in 1972: "All people are by nature free and independent and have inalienable rights. Among these are ... pursuing and obtaining safety, happiness, and privacy."204 California courts have interpreted this provision as extending further than the federal right to privacy, ${ }^{205}$ and have applied it in a wide variety of contexts. ${ }^{206}$ As with the federal right, however, the exact dimensions of the California right to privacy remain unsettled. For example, although the weight of authority indicates that the California right to privacy protects against intrusions by both the state and private actors, ${ }^{207}$ some courts have questioned this doctrine, and the state supreme court has not resolved the issue. ${ }^{208}$

In defining the contours of the California right to privacy, courts have used the Fourth Amendment standard that a "reasonable expectation of privacy" will trigger privacy protections, ${ }^{209}$ and have found that "improper use

204. Cal. Const, art. I, $\S 1$.

205. E.g., Chico Feminist Women's Health Ctr. v. Scully, 256 Cal. Rptr. 194, 199 (Ct. App. 1989) ("[O]ur state privacy guarantee is broader than the federal privacy right.").

206. See, e.g., White v. Davis, 533 P.2d 222, 234 (Cal. 1975) (holding that police surveillance of classrooms violates right to privacy); Central Valley Chapter of the 7th Step Found., Inc. v. Younger, 262 Cal. Rptr. 496, 505-06 (Ct. App. 1989) (holding that a state agency's dissemination of job applicants' nonconviction arrest and detention records violates right to privacy); Cuttcr v. Brownbridge, 228 Cal. Rptr. 545, 549-50 (Ct. App. 1986) (right to privacy encompasses communications between patient and psychotherapist).

207. White, 533 P.2d at 242; see also Soroka v. Dayton Hudson Corp., 1 Cal. Rptr. 2d 77, 83 (Ct. App. 1991) (state action not required for claim of violation of right to privacy), review granted, 822 P.2d 1327 (Cal. 1992); Porten v. University of San Francisco, 134 Cal. Rptr. 839, 843-44 (Ct. App. 1976) (affirming cause of action against a private university for improper use of information).

208. See Schmidt v. Superior Court, 769 P.2d 932, 944 n.14 (Cal. 1989) ("[W]e have no occasion in this case to consider under what circumstances, if any, purely private action . . . would constitute a violation of the state constitutional privacy provision."); see also Wilkinson v. Times Mirror Corp., 264 Cal. Rptr. 194, 199, 203 (Ct. App. 1989) (discussing the lack of clear guidance provided by the Califorma Supreme Court on the issue of private action).

209. E.g., Armenta v. Superior Court, 132 Cal. Rptr. 586, 588 (Ct. App. 1976) ("The basic test of whether there has been a violation of this [privacy] right is if a person's personal and objectively reasonable expectation of privacy has been infringed by unreasonable governmental intrusion."); $c f$. 
of information properly obtained" may conflict with such protections. ${ }^{210}$ Indeed, personal control of information about oneself and one's own affairs was a central aspect of the ballot argument supporting passage of the privacy right. ${ }^{211}$ Under this standard, someone in rightful possession of information about a patient, such as a physician with HIV-related information, may violate the constitutional privacy provision if he or she unjustifiably discloses that information.

Cahfornia doctrine, like federal doctrine, does not establish an absolute right to privacy even when the plaintiff can prove a reasonable expectation of privacy. In California, however, courts require a showing of a compelling state interest to overcome the individual's privacy right. ${ }^{212}$ In the HIV context, the state will generally meet this burden, as courts give the state wide latitude when it acts under the banner of public health. ${ }^{213}$ However, the courts impose on the state the additional hurdle of proving that the proposed action, for example, obtaining information, is "necessary" to achieve the claimed interest. ${ }^{214}$

California courts have found that the right of privacy encompasses medical information in general and HIV-related information in particular. Disclosure of information contained in an individual's medical records violates the right to privacy, ${ }^{215}$ unless justified by a compelhing state interest. $^{216}$ In the recent case of Urbaniak $v$. Newton, ${ }^{217}$ the court found that an HIV-positive person had a privacy cause of action against a physician who,

supra notes $174-76$ and accompanying text (discussing use of Fourth Amendment standard in federal privacy case).

210. White, 533 P.2d at 234; see also Porten, 134 Cal. Rptr. at 842.

211. "'Fundamental to our privacy is the ability to control circulation of personal information. This is essential to social relationships and personal freedom."' Wilkinson, 264 Cal. Rptr. at 198 (emphasis omitted) (quoting the 1972 ballot argument in favor of amending the Califormia Constitution to include a right of privacy).

212. White, 533 P.2d at 234-35; Wood v. Superior Court, 212 Cal. Rptr. 811, 819-20 (Ct. App. 1985). Application of a "compelling state interest" requirement, however, has not been uniform. In Wilkinson, for example, the court interpreted the California Supreme Court's decision in Schmidt, 769 P.2d at $944-45$, as requiring a showing of compelling state interest only when the plaintiff's right to privacy has been "substantially burdened or affected." Wilkinson, 264 Cal. Rptr. at 203. In the absence of such a burden or effect, the court will engage in a simple balancing of the individual's interest in privacy and the government's claimed interest. Id. at 203-04. In Soroka v. Dayton Hudson Corp., 1 Cal. Rptr. 2d 77, 83-84 (Ct. App. 1991), review granted, 822 P.2d 1327 (Cal. 1992), the court rejected Wilkinson and instead followed the line of authority set out in White and Wood, requiring the state to show a compelling interest.

213. See, e.g., Ex parte Johnston, 180 P. 644, $644-45$ (Cal. Dist. Ct. App. 1919) (permitting quarantine for venereal disease carrier and stating that "the Legislature is necessarily vested with large discretion, not only in determining what are contagious and infectious diseases, but also in adopting means for preventing the spread thereof'); In re Halko, 54 Cal. Rptr. 661, 664-65 (Ct. App. 1966) (upholding six month isolation of tuberculosis patient in hospital).

214. Wood, 212 Cal. Rptr. at 820.

215. Id. at 819; Division of Medical Quality, Bd. of Medical Quality Assurance v. Gherardini, 156 Cal, Rptr. 55, 61 (Ct. App. 1979).

216. Johnetta J. v. Municipal Court, 267 Cal. Rptr. 666, 683 (Ct. App. 1990).

217. 277 Cal. Rptr. 354 (Ct. App. 1991). 
after the plaintiff disclosed his HIV status to the physician's assistant, passed that information along to the attorney for the insurer of the plaintiff's employer. The court held that the physician's disclosure, while falling short of a tortious breach of privacy, constituted the "improper use of information properly obtained."218

Although the Califorma right to privacy would almost certainly cover such simple instances of unauthorized, unwarranted disclosure as in Urbaniak, it might not support a claim arising from a harmful disclosure by a health care provider if the disclosure were related to the individual's compensation claim. In some cases, this will be because the plaintiff put his or her medical condition, includimg HIV status, at issue. ${ }^{219}$ In others, the court might order disclosure of HIV-related information by a party that had not itself put the matter directly at issue. ${ }^{220}$ The crucial difference between these types of cases is that in the former, the party with the potentially harmful HIV-related information remains in control. Although the individual may face the difficult choice of dropping a claim or disclosing HIVrelated information, the decision remains his or her own. ${ }^{221}$ In the latter situation, the court decides the matter and imposes its decision on the individual.

There are other important limitations on the scope of privacy protections afforded by the California constitution. Perhaps the most significant is the deference given the state in implementing public health programs. In California, as in the federal arena, privacy protections will pose little barrier to the growth of aggressive measures like name reporting and partner notification.

Moreover, some uncertainty remains as to whether the right of privacy encompasses strictly private action. ${ }^{222}$ Although the bulk of authority suggests private actors are covered, the California Supreme Court has yet to rule on the issue. Indeed, it is striking that, as late as the $1989 \mathrm{Schmidt}$ decision, the Court expressiy stated that the question remains open. This uncertainty indicates that the sweep of California's privacy protection is perhaps not as broad as it might first appear. ${ }^{223}$

218. Id. at 359 (quoting White v. Davis, 533 P.2d 222, 234 (Cal. 1975)).

219. For example, if a plaintiff sued an employer under the Americans with Disabilities Act for failure to accommodate an HIV-related disability, the plaintiff's HIV status would be at issue and would probably be disclosed in court.

220. See, e.g., Agosto v. Trusswal Sys. Corp., 142 F.R.D. 118, 120-21 (E.D. Pa. 1992) (requiring a confidential disclosure of patient's HIV-related information when relevant to calculating damages based on lost earning capacity); Federal Judge's Order in Lost Earnings Suit Could "Open Door" to Testing, Attorney Says, AIDS Poz'y \& L. (Euraff Publications, Washington, D.C.), May 15, 1992, at 1.

221. Of course, this "choice" may not be meaningful if the individual must disclose her HIV status in order to qualify for needed compensation.

222. See supra notes 207-08 and accompanying text.

223. Another possible source of uncertainty derives from the California courts' frequent reference to federal Fourth Amendment "reasonable expectation of privacy" jurisprudenee. See supra note 209 and accompanying text. In recent years, the United States Supreme Court has developed a doctrine of "special needs" under which governmental intrusion into personal privacy can be justified absent either 


\section{Common Law Privacy Causes of Action}

Disclosure of HIV-related information is also potentially actionable under common law contract and tort theories. Most common law actions for violation of privacy concern disclosure of private information to the public, often through the media. ${ }^{224}$ Since disclosures of medical information often lack a public dimension, courts have developed specific bases for common law privacy actions in the medical context. 225

For example, courts have found that unauthorized disclosure of medical information by a physician may violate the physician's duty of confidentiality ${ }^{226}$ or the implied contract of confidentiality between the physician and the patient. In Hammonds v. Aetna Casualty \& Surety Co., ${ }^{227}$ for example, a federal district court held that an implied contract of confidentiality existed between a physician and patient, and that disclosure of information obtained during treatment without the patient's permission was grounds for a breach of contract claim. ${ }^{228}$ A court following this reasoning would find a cause of action, based on the implied contract and the physician's duty of confidentiality, for a plaintiff whose physician divulged HIV-

a warrant or probable cause: "[W] here a Fourth Amendment intrusion serves special governmental needs, beyond the normal need for law enforcement, it is necessary to balance the individual's privacy expectations against the Government's interests to determine whether it is impractical to require a warrant or some level of individualized suspicion in the particular context." National Treasury Employees v. Von Raab, 489 U.S. 656, 665-66 (1989). In Love v. Superior Court, 276 Cal. Rptr. 660, 663-64 (Ct. App. 1990), a California court of appeal applied the "special needs" doctrinc to a privacy claim concerning mandatory testing of previously convicted prostitutes. Although the privacy claim im Love was based on the Fourth Amendment, rather than the Califomia Constitution, the case may portend the development of more gaps in Califomia privacy law, given California courts' use of Fourth Amendment law in deciding Califorma privacy cases. See also Johnetta J. v. Municipal Court, 267 Cal. Rptr. 666 (Ct. App. 1990).

224. See, e.g., Schwartz v. Thiele, 51 Cal. Rptr. 767, 771 (Dist. Ct. App. 1966) (" 'The gravamen of the tort [of invasion of privacy] is ordinarily the unwarranted publication by defendant of intimate details of plaintiff's private life." ") (quoting Coverstone v. Davies, 239 P.2d 876, 880 (1952)).

225. See Peter J. Nanula, Comment, Protecting Confidentiality in the Effort to Control AIDS, 24 HARV. J. ON LEGIS. 315, 334-35 (1986).

226. Courts have found such a duty on various grounds, including state licensing requirements and the statutory testimonial privilege covering physician-patient communications. See, e.g., Horne v. Patton, 287 So. 2d 824, 829-30 (Ala. 1973) (grounding its determination that doctors have a duty of nondisclosure of patients' medical records in state hicensing requirenients that suggest public policy in favor of confidential treatment of patient information); Simonsen v. Swenson, 177 N.W. 831 (Neb. 1920) (holding that a cause of action for breach of confidentiality lies when a physician violates a statutory physician licensing standard requiring confidential treatment of patient information); Schaffer v. Spicer, 215 N.W.2d 134, 136 (S.D. 1974) (finding that a statute-based duty of physician-patient confidentiality renders a physician liable for unauthorized disclosure of information); Berry v. Moench, 331 P.2d 814, 817 (Utah 1958) (basing physician's duty of confidentiality on state physician testimonial privilege statute). See generally Michael B. McVickar, Note, To Disclose or Not to Disclose the Presence of AIDS: Resolving the Confidentiality Concerns of Patients, Physicians, and Third Parties, 23 VAL. U. L. REv. 341, 350-53 (1989) (examining state statutory bases of liability for improper disclosure by physicians, including state licensing and testimonial privilege statutes).

227. 243 F. Supp. 793 (N.D. Ohio 1965).

228. Id. at 801-02; see also Doe v. Roe, 400 N.Y.S.2d 668, $674-75$ (Sup. Ct. 1977) (finding a breach of implied contract of confidentiality when a physician disclosed information in a published book that had bcen revealed by a patient during psychotherapy). 
related information to the plaintiff's employer, landlord, or other individual without the plaintiff's consent. ${ }^{229}$

The physician's duty to maintain confidentiality may in certain circumstances conflict with the duty to warn a known, unsuspecting person who may be in imminent danger of harm from a patient's action. This "duty to disclose" is often dated from the California Supreme Court's decision in Tarasoff $v$. Regents of the University of California, ${ }^{230}$ which established that a psychotherapist could be liable in tort for failing to warn a patient's former girlfriend that the patient might attempt to kill her. ${ }^{231}$

The initial shock waves which Tarasoff produced in the medical (and other) profession subsided somewhat after later decisions narrowed the scope of the duty to situations in which a specific, known individual is subject to specific, known, and imminent harm, rather than situations of generalized threats of harm posed by a patient or client. ${ }^{232}$ The potential application of this duty to warn-which, of course, inherently means a duty to breach confidentiality - is obvious in the case of HIV: if a physician (or other provider) knows that an HIV-positive patient has a sexual partner and that the patient intends to continue unsafe sexual practices without warning that partner, the physician nuay have a duty to warn. ${ }^{233}$

On a more general level, disclosure of HIV-related information may give rise to a tort claim based on invasion of privacy. ${ }^{234}$ Four basic causes of action come under the invasion of privacy rubric, ${ }^{235}$ the most relevant here being public disclosure of private facts. The Restatement (Second) of Torts defines this claim as publicizing "the private life of another" in a way that "(a) would be highly offensive to a reasonable person, and (b) is not of

229. The physician's duty to the patient may be less clear in certain cases. In Urbaniak v. Newton, 277 Cal. Rptr. 354, 356 (Ct. App. 1991), for example, the plaintiff's employer retained the physician and therefore the usual physician-patient relationship-and the implied duty of confidentiality-may not have applied.

230. 551 P.2d 334 (Cal. 1976).

231. Id. at 353.

232. See, e.g., Thompson v. County of Alameda, 614 P.2d 728, 735-38 (Cal. 1980).

233. These issues have been discussed at length elsewhere. See, e.g., Richard C. Turkington, Confidentiality Policy for HIV-Related Information: An Analytical Framework for Sorting Out Hard and Easy Cases, 34 VILL. L. REv. 871, 873 (1989) (examining the role that confidentiality should play in governmental responses to the AIDS epidemic); Jeff Glenney, Note, AIDS: A Crisis in Confidentiality, 62 S. CAL. L. Rev. 1701, 1702 (1989) (suggesting principles to mediate the conflict in AlDS cases between the patient's interest in confidentiality and the state's interest in disclosure); McVickar, supra note 226, at 342 (exploring the confidential relationship between physicians and their patients, and the effeets AIDS may have on that relationship).

234. One possible tort action that has never been successfully employed for violation of privacy is the tort of defamation. See McVickar, supra note 226, at 355-56.

235. See W. Page Keeton et al., Prosser and Keeton on the Law of Torts $\$ 117$ (5th cd. 1984) (discussing the four bases of privacy torts: appropriation of a name or likeness, unrcasonable intrusion upon the seelusion of another, creation of a false light in the public eye, and public disclosure of private facts). 
legitimate concern to the public."236 In a leading case, the Alabama Supreme Court found such a tortious invasion of privacy when a physician disclosed information obtained during treatment to the patient's employer. ${ }^{237}$

Because HIV-related disclosures are likely to occur at an individual rather than public level, most plaintiffs in HIV cases would have difficulty satisfying the "public disclosure" element of the tort. Courts in numerous cases have considered the question of what amount, or what type, of disclosure is sufficient to support a public disclosure of private facts claim. These cases make at least two things clear: disclosure must be made to a number of people to support a claim; ${ }^{238}$ and publicizing allegedly "private facts" is permitted if the facts are of legitimate public interest or to some degree already in the public domain. ${ }^{239}$

Intrusion into an individual's private affairs might also give rise to a tort claim. ${ }^{240}$ Injury to an individual's interests in "solitude or seclusion" may be grounds for a suit when such intrusion would be "highly offensive to a reasonable person."241 An HIV-related intrusion would be actionable if the defendant physically invaded part of the plaintiff's personal realm, such as personal records, personal mail, or medical files, without authority or authorization to do so. Unlike the "publicity" privacy tort, an "intrusion" claim does not depend on publicity; the invasion itself provides grounds for a claim.

These common law approaches to dealing with breaches of HIVrelated confidentiality have only limited utility. First, and most obviously, tort and contract law can do nothing to restore a person's privacy once

236. Restatement (SECOND) OF TORTS $§ 652 D$ (1976). In California, the elements of the tort have been stated as the "(1) public disclosure (2) of a private fact (3) which would be offensive and objectionable to the reasonable person and (4) which is not of legitimate public concern." Diaz v. Oakland Tribune, Inc., 188 Cal. Rptr. 762, 768 (Ct. App. 1983).

237. Horne v. Patton, 287 So. 2d 824, 829-30 (Ala. 1973); see also Hammonds v. Aetna Casualty \& Sur. Co., 243 F. Supp. 793, 801-02 (N.D. Ohio 1965) (holding that an unauthorized disclosure of information violated patient's privacy); Doe v. Roe, 400 N.Y.S.2d 668, 674-75 (Sup. Ct. 1977) (finding an invasion of privacy when a psychiatrist made extensive disclosures about a former patient).

238. See, e.g., Kinsey v. Macur, 165 Cal. Rptr. 608, 611 (Cal. App. 1980) ("[E]xcept in cases involving physical intrusion, the tort must be accompanied by publicity in the sense of communication to the public in general or to a large number of persons as distinguished from one individual or a few."); Porten v. University of San Francisco, 134 Cal. Rptr. 839, 841 (Ct. App. 1976) (finding that the university's disclosure of plaintiff's transcript to a scholarship service did not amount to the publicity required to trigger privacy tort); Timperley v. Chase Collection Serv., 77 Cal. Rptr. 782, 784 (Ct. App. 1969) (rejecting claim based on defendant's disclosure to plaintiff's employer: "The disclosure of private facts must be a public disclosure, and not a private one; there must be, in other words, publicity.' ") (citation omitted)).

239. See Sipple v. Chronicle Publishing Co., 201 Cal. Rptr. 665, 668-71 (Ct. App. 1984) (holding that a newspaper's publicizing of plaintiff's homosexuality was permissible because plaintiff lived a relatively "open" life as a gay man and because plaintiff's act in thwarting a presidential assassin made his life newsworthy).

240. Restatement (SECOND) OF TORTS $§ 652 B$ (1976).

241. Id. 
violated. Second, like any lawsuit, tort or contract suits can take years to wend their ways through the court system, and an HIV-affected plaintiff may only be able to benefit from rapid recovery. This is particularly true with privacy tort actions, which are available only to the person whose privacy is invaded, and do not survive that person's death. ${ }^{242}$ In HIV-related cases, this fact provides a potentially powerful disincentive to the plaintiff to go forward and an equally strong incentive for a defendant to drag the case out. Third, when there is no demonstrable economic harm suffered by the plaintiff from the disclosure, he or she may be unable to recover more than nominal damages. ${ }^{243}$ Contract remedies, in particular, are generally himited to those damages necessary to restore the plaintiff to her pre-breach position. Fourth, providers of HIV-related services are often nonphysicians, who would not be subject to the more readily available common law claims based on the unique nature of the physician-patient relationship. ${ }^{244}$ Finally, to bring a suit based on common law theories, a plaintiff must discover that a breach has occurred in the first place. Given the reality that such breaches may occur between government agencies or private parties without the would-be plaintiff's knowledge, many potential suits will never even be brought. ${ }^{245}$

\section{Summary}

Constitutional privacy rights and common law theories comprise the broadest net to deter and offer recourse for breaches of confidentiality not covered by the HIV-specific and general medical confidentiality statutes. However, neither constitutional nor common law privacy rights provide sufficient protection for confidentiality. Constitutional rights to informational privacy may be overcome by a sufficient state interest, and common law protections apply only under certain conditions, such as sufficient pubhicity to constitute a breach of privacy tort. In addition, both constitutional and common law protections serve primarily remedial purposes by offering remedies for persons whose privacy rights or interests are violated. While this is of course crucial, deterring disclosures in the first place is arguably more important. Such deterrence is more likely to come from narrower

242. Lugosi v. Universal Pictures, 603 P.2d 425, 430 (Cal. 1979) ("[T] he right does not survive but dies with the person." (quoting Hendrickson v. California Newspapers, Inc., 121 Cal. Rptr. 429, 431 (Ct. App. 1975))); Wemer v. Times-Mirror Co., 14 Cal. Rptr. 208, 211 (Ct. App. 1961) ("The right of privacy is a purely personal one. It cannot be asserted by anyone other than the particular person whose privacy is invaded.").

243. See Ann H. Britton, Rights to Privacy in Medical Records, J. Legal Med., July-Aug. 1975, at $30,37$.

244. See Wendy Parmet, Comment, Public Health Protection and the Privacy of Medical Records, 16 HARv. C.R.-C.L. L. REv. 265, 274 (1981) ("As of 1976 . . . physicians provided less than five pcrcent of the health care services in America.").

245. See Michael W. Miller, Patients' Records Are Treasure Trove for Budding Industry, WALL Sr. J., Feb. 27, 1992, at A1 ("Specialists in privacy issues say . . . that most violations of mcdical confidentiality never come to the attention of patients."). 
safeguards, for medical information and for HIV information in particular, than from sweeping constitutional and common law protections.

\section{Functioning of the Three Levels of Privacy Protection}

The three levels of confidentiality protection discussed in the Sections above-statutory protection for HIV-specific information, statutory protection for medical information, and constitutional and common law privacy rights-function as a tri-level net to catch possible disclosures of HIVrelated information. In California, the first level of protection consists of the Health and Safety Code's HIV confidentiality statute. ${ }^{246}$ It provides concrete grounds for legal action in many cases, including civil or even criminal action for the disclosure of the record of an "HIV test" result by any party. ${ }^{247}$ This level will catch, for example, the case of an unauthorized disclosure of HIV test results by a physician, other service provider, or private individual. However, given the limits placed on the definition of "HIV test" result ${ }^{248}$ and the narrow reading of the law in Urbaniak, ${ }^{249}$ the Health and Safety Code provisions will miss some cases where confidentiality is a real concern. For example, after Urbaniak, verbal disclosure of one's HIV status-not the test result itself-does not appear to trigger the protections of the statute. If a service agency worker were to learn of an individual's serostatus or AIDS-related condition and pass that information along to others, including an einployer or an insurer, the individual might not be able to invoke the statute and seek a remedy.

Such a disclosure might, however, be covered under the second level of the confidentiality protection net, the level of general medical information confidentiality. So long as the information concerned is possessed by or originates from a health care provider, the Confidentiality of Medical Information Act should prohibit disclosure not authorized by the patient. ${ }^{250}$ Had the plaintiff in Urbaniak used the CMIA as a basis for his suit, for example, the court might have found the broader scope of the CMIA's prohibitions to encompass the defendant's disclosure. The disclosure did not appear to fall within one of the statutory exceptions for mandatory or permissive disclosure of medical information, ${ }^{251}$ and both the nurse and physician were "[p]rovider[s] of health care." 252 However, although the court in Urbaniak apparently found irrelevant the possible link, reported by the defendant physician, between plaintiff's HIV status

246. Cal. Health \& Safety Code $\$ 199.20-44$ (West 1990 \& Supp. 1993); see supra notes 12437 and accompanying text.

247. Id. $\S 199.21$

248. See id. § 26; supra note 126 and accompanying text.

249. Urbaniak v. Newton, 277 Cal. Rptr. 354 (Ct. App. 1991); see supra notes 138-44 and accompanying text.

250. See supra notes $157-68$ and accompanying text.

251. CaL. Crv. CodE $\S 56.10($ b)-(c) (West 1982 \& Supp. 1993).

252. Id. $\$ 56.05(\mathrm{~d})$. 
and his muscular dysfunction, a court in a case with a closer relationship between a plaintiff's condition and HIV status might find that disclosure fits within the exceptions of the CMIA. ${ }^{253}$

While the CMIA might have helped the plaintiff in Urbaniak, it does not cover all situations which might raise confidentiality concerns. ${ }^{254}$ Information handled by persons not defined by the CMIA as health care providers, for exaunple, might not come within the Act. Furthermore, because the CMIA explicitly allows disclosures permitted by other provisions of the Code, ${ }^{255}$ it would provide no protection for HIV-related information the disclosure of which was called for by a change in statute.

Those breaches of confidentiality which neither the HIV-specific statute nor the general medical information statute cover may come under the third level of confidentiality protection, that provided by constitutional and common law privacy doctrines. Either or both of these doctrines may provide a remedy for any violation of an individual's right to privacy. Federal constitutional claims can stand only where there is state action of some kind, such as disclosures made by state employees or agencies. California state constitution claims may be similarly limited. For example, were a state department of health employee with access to a registry of HIVinfected persons to inform a third party of the presence of a person's name on that registry, the HIV-positive person would have a cause of action based on the violation of his or her constitutional right to privacy. Disclosures by private individuals may, if sufficiently serious, fall within the scope of common law contract or tort doctrines. If, for exainple, the neighbor of a person with AIDS were to publish that person's HIV status in a neighborhood newspaper to alert or inform others, the person with AIDS might have a cause of action for invasion of privacy. However, pursuit of constitutional or common law remedies has several disadvantages, including the traditional judicial deference to the state in the area of public health. ${ }^{256}$ Finally, all of these protections suffer from two common defects. First, none is able to restore the value of something that has been lost by a breach of confidentiality: the individual's privacy. Second, HIV-infected persons may be neither willing nor able, physically or emotionally, to withstand the stress of litigation. ${ }^{257}$ Both of these limitations underscore the importance of deterring breaches before they happen.

253. See supra notes $160-64$ and accompanying text.

254. See supra text accompanying note 168.

255. CAl. Civ. Code § 56.10(c)(13) (West Supp. 1993).

256. See supra Part III.C.3-4.

257. See David Schulman, AIDS, The Law, and Society, L.A. LAw., Sept. 1988, at 19, 26. 


\section{IV}

\section{The Resurgence of Aggressive Public Health Strategies and Present Protections for Confidentiality}

The three levels of confidentiality protection appear to provide effective deterrence and remedies for potential breaches of the confidentiality of HIV-related information. Each, however, has its limitations. Moreover, the strength of these safeguards has not been tested against the new pressures on confidentiality. Faced with the resurgence of aggressive and intrusive public health measures in the volatile context of AIDS/HIV politics, the three levels of protection as now constituted are inadequate to serve the dual function of preserving civil liberties and promoting public health.

\section{A. Mandatory Name Reporting}

None of the levels of confidentiality protection is likely to hinder sigmificantly the implementation of mandatory name reporting policies. ${ }^{258}$ Although California, under the HIV confidentiality statute, bars some reporting of individually identifiable information, ${ }^{259}$ it permits local or state public health agencies to disclose personally identifiable information contained in public health records whenever such disclosure is "provided by law for public health purposes"260 or "when the confidential information is necessary to carry out the duties of the agency ... in the investigation, control, or surveillance of disease, as determined by the state or local public health agency."261 Existing laws thus would not pose a barrier to a mandatory name reporting program.

Constitutional and common law protections would only minimally address confidentiality concerns raised by name reporting. Any such program itself would almost certainly not be open to challenge on constitutional or common law grounds, due to the latitude that courts give states in the public health arena. ${ }^{262}$ However, disclosures by the state of names from the registry might be actionable if not sufficiently tailored to a legitimate state interest. For example, if a state department of health were to disclose names to a hospital wanting to screen applicants for health care positions, an affected person would likely have a constitutional claim, particularly under the California Constitution. ${ }^{263}$ However, in a less dramatic scenario, such as disclosure of a list of names to a hospital wanting to screen appli-

258. When Tennessee initiated mandatory name reporting in 1992, various plaintiffs brought suit to block implementation of the law. The court upheld the law. Judge Finds No Reason to Halt HIV Test Reporting Requirement, AIDS PoL'Y \& L. (Buraff Publications, Washington, D.C.), Jan. 23, 1992, at 2.

259. The statute allows disclosure of a patient's seropositivity by a physician or other provider to the county health officer, without inclusion of any individually identifiable information about the patient. Cal. Health \& SAFETY Code $§ 199.25$ (West 1990).

260. Id. § 199.42(a).

261. Id. \& 199.42(b).

262. See supra text accompanying note 23 and Part III.D.

263. See supra Part III.C.1-2. 
cants for a heart surgeon position, a court might find the fit between the state's interest and action sufficiently close to uphold the statute, especially if the court took the rise in aggressive public health measures to indicate the strength of the state's interest in controlling the spread of HIV infection.

Constitutional or common law theories would cover only state or private actions exceeding the bounds of statutory authority. In the first scenario described above, federal constitutional law might support a claim based on the individual's protected interest in preventing disclosure of personal information, ${ }^{264}$ while California constitutional law would allow recourse for "improper use of information properly obtained."265 Common law would probably provide a cause of action only if the disclosure took a public form, ${ }^{266}$ and would in any event suffer from the limitations inherent in common law remedies. ${ }^{267}$

The lack of protection against name reporting might appear to be of no great concern, as the record of public health agencies, including California's, for maintaining confidentiality is good. But the prospect of name reporting is of concern, in large part because all AIDS policy is subject to the vicissitudes of politics and public opinion. Mandatory name reporting programs would result in the state amassing individually identifiable HIV-related information, generating precisely the sort of registry called for under the Illinois statute ${ }^{268}$ to track down potentially HIV-exposed health care workers and patients. Even though public health officials would be likely to oppose nonsurveillance uses of names, once a list exists, those officials could not control its use.

Moreover, the possibility exists that California may enact an Illinoistype statute, through either the legislative or voter initiative process. Indeed, voters set the precedent in 1988 of amending the statute to allow greater disclosure. Declaring that "AIDS, AIDS-related conditions, and other commumicable diseases pose a major threat to the public health and safety," the voters of California adopted Proposition 96, permitting victims of sex crimes as well as police, firefighters, and emergency medical personnel in certain circumstances ${ }^{269}$ to petition the court to order an HIV test.

264. See supra notes 188-203 and accompanying text.

265. See supra note 210 and accompanying text.

266. See supra notes 235-39 and accompanying text. A claim for intrusion into private affairs, which does not require public disclosure, would not be appropriate under this sccnario because the information would properly be in the hands of the disclosing party. See supra notcs $240-41$ and accompanying text.

267. See supra notes $242-45$ and accompanying text.

268. ILL. ANN. StAT. ch. 410, \&325/5.5 (Smith-Hurd 1993); see supra notes 94-97 and accompanying text.

269. Cal. Health \& SAfety Code $\S \S 199.95-.99$ (West 1990). In addition to the provision regarding sexual assault victims, the statute allows such personnel to petition for a testing order for "[a]ny person charged in any criminal complaint ... [with] interfer[ing] with the official duties of a peace officer, firefighter, or emergency medical personnel hy biting, scratching, spitting, or transferring blood or other bodily fluids on, upon, or through the skin or membranes of a peace officer, firefighter, or emergency medical personnel." Id. § 199.97 . 
The amendment requires confidential treatment of information, ${ }^{270}$ but its popular enactment raises the specter of other, broader exceptions to the statute. This is particularly so given the increasing popular as well as elite antagonism to treating AIDS differently than STDs, ${ }^{271}$ combined with the contimuing reality of widespread public fears about AIDS. Proposition 96 was born and passed within an atmospliere of heated debate and hysteria about the epidemic. ${ }^{272}$ Such an atmosphere could easily develop once again, leading to enactment of similarly intrusive policies, or worse. ${ }^{273}$

Although health care employment provides the most obvious area for state legislative activity, it is easy to conceive of others. Patients, especially those in hospitals, are possible objects of aggressive health measures. Outside the health care context, a legislature (or the voters by referenduni) might determine that the welfare of children demands that they not be in the custody of HIV-infected parents, who could be identified using state lists. Prisoners might make another invitimg target.

The implications for confidentiality are serious. If statutes such as that enacted in Illinois are enforced, confidentiality of HIV-related information will necessarily be breached. The individual's control over the use and dissemination of information ends where the state's control begins. Additionally, the increased access inherent in aggressive programs would threaten a range of confidentiality breaches. For example, if a patient of an HIV-infected health care worker were informed of the health care worker's HIV status (and, therefore, the patient's possible exposure to HIV), the (former) patient could inform others of that status. Although the patient might violate the statute, and at some point even tortiously violate the health care worker's privacy, ${ }^{274}$ the danger of a sort of creeping loss of confidentiality is real, particularly given practical difficulties of preventing or discovering disclosure among personal acquaintances. Moreover, statutory and civil remedies cannot restore confidentiality nor significantly allay the fear that further disclosure will follow the imitial breach. Finally, such practices would inevitably discourage people froin getting tested for HIV, since they would then rightly fear that a positive result would put their names on a list that may be used in ways that harm them. ${ }^{275}$

270. Id. §§ 199.98(e), 199.99(d)-(e).

271. See supra notes $69-70$ and accompanying text.

272. See Kevin Roderick, The Other AIDS Initiative on Tuesday's Ballot, L.A. Times, Nov. 5, 1988, at 31 .

273. Indeed, the Kimberly Bergalis case illustrates how easily and quickly a single, well-publicized tragedy can create mass hysteria sufficient to transform state and national politics. See supra note 77.

274. The potential tort would most likely be based on the "public disclosure of private facts" branch of invasion of privacy, which requires a showing of public disclosure beyond a small circle. See supra notes 235-39 and accompanying text.

275. See Mike McKee, Bäd Blood, Recorder, Mar. 25, 1993, at 1, 7 (reporting comments by Director of San Francisco AIDS Office that name reporting would cause people to avoid health care system); see also supra notes 56-57, 62 and accompanying text. 
While mandatory name reporting schemes raise serious threats to confidentiality, they offer relatively little demonstrable benefit to public health. The chief rationales given for requiring named reporting do not bear up under scrutiny, especially when weighed against the potential harm done to confidentiality. Some advocates of name reporting argue that, if the state has names of HIV-positive people, it can ensure that they are linked to available services and treatment. ${ }^{276}$ In actual practice, however, the resources simply do not exist for such linkage to occur. ${ }^{277}$ But the most frequent justification is that named reporting provides the best, most accurate information for surveillance purposes because it ensures against duplication of case counting. ${ }^{278}$ Yet there is little evidence that duplication occurs so frequently as to invalidate overall surveillance data generated. ${ }^{279}$ Moreover, it is possible to use a system of anonymous, nonname identifiers that ascribe a unique alphanumeric code to each reported individual. ${ }^{280}$ The sole link between a name and the unique identifier lies in the physician's or clinic's office-precisely where it would be were there no reporting to the state at all. A unique identifier system can avoid the confidentiality problems created by name reporting, while still preserving the claimed surveillance benefit. ${ }^{281}$

Name reporting, in sum, accomplishes little benefit for the public health battle against AIDS, and simultaneously poses serious dangers to confidentiality. Because present protections for HIV-related information are inadequate to safeguard against the institution and/or abuse of name reporting systems, new protections must be developed.

276. See, e.g., Kathleen E. Toomey \& Willard Cates Jr., Partner Notification for the Prevention of HIV Infection, 3 AIDS S57, S58 (Supp. 1 1989).

277. See, e.g., StolL, supra note 103, at 10-11; David E. Rogers \& June E. Osborn, Another Approach to the HIV Epidemic, 325 NEw ENG. J. MED. 806, 808 (1991) (Chair and Vice-Chair of National Commission on AIDS labeling policy of testing without ensuring access to services "cruel and irresponsible"); CDC's Campaign to Promote HIV Testing Lacks Treatment Funds, AIDS Panel Told, AIDS PoL'y \& L. (Buraff Publications, Washington, D.C.), Feb. 21, 1990, at 1;.

278. See, e.g., Franklyn N. Judson, Partner Notification for HIV Control, Hosp. Prac., Dec. 15, 1990 , at 65 .

279. Moreover, given that the great majority of test sites (outside of private physician offices) do not require positive identification, people can and do use pseudonyms, which effectively reach the same result as anonymous testing.

280. Orcgon, for example, has begun to implement a system that uses nonname unique identifiers for reporting purposes. See Letter from Katrina Hedburg \& Steve Modesitt, Oregon Departmcnt of Human Resources, to Laboratory Direetors (Dec. 21, 1992) (on file with author) (explaining that a patient name or coded identifier must aecompany each report of an HIV/AIDS case).

281. Unique identifier systems have received broad support from many advocacy organizations as alternatives to named reporting. See, e.g., Elizabeth B. Cooper \& Paul Di Donato, In the Field, AIDS PoL'y \& L. (Buraff Publications, Washington, D.C.), Feb. 5, 1993, at 6. 


\section{B. Partner Notification and Contact Tracing}

\section{Potential Hazards of Expanded Partner Notification Programs}

Expanded partner notification programs present several potential dangers to confidentiality. First, responsibility for partner notification may shift further from the provider to the state public lealth department. The California Medical Association, for example, has considered proposing an amendment to the HIV confidentiality statute for introduction to the California legislature that would permit doctors to pass information about HIV-positive persons along to the county health officer for county-initiated partner notification. ${ }^{282}$ Even this relatively minor change would boost considerably the number of names coming into the state's possession. Although the record of California agencies in maintaining the confidentiality of HIV infornation is solid to date, there may yet be real concern among many of the target groups for HIV public health programs (who, as discussed above, are deeply mistrustful of state intentions) over how this expanded pool of information will be used.

The second danger echoes a concern which arises in the name reporting context. The more widespread and intensive notification becomes, the greater potential there is for negligent or purposeful disclosure of confidential information by those administering the program. This is particularly true of a state-administered program, which would centralize information drawn from health care providers.

Third, aggressive partner notification markedly affects the control dimension of confidentiality by shifting the locus of control away from the individual and toward the state or other party involved in notification efforts. To a significant extent, of course, the HIV-positive person being encouraged to divulge names for notification necessarily retains control simply because he or she can choose not to reveal anything. However, even in the absence of overt pressure from a partner notification counselor, an HIV-positive person might believe that cooperation in the program is a prerequisite to access to needed medical and support services. This dynamic might be especially strong among those who lack private health insurance and depend on the state for many of their health services.

Fourth, partner notification programs involving women who are HIV positive may directly increase the risk of domestic violence. ${ }^{283}$ If and when the partner of a woman with HIV infection learns of the woman's status, he may conclude (quite possibly erroneously) that the woman was infected

282. Interview with Amy Wright, California Medical Association, in San Francisco, Cal. (May 14, 1993).

283. While battering relationships also exist among same-sex couples, including gay men, concern about the implications of partner notification programs for domestic violence has surfaced primarily in the context of heterosexual relationships. Therefore, this discussion focuses on women at risk. 
through sex or needle activity outside the relationship. ${ }^{284}$ Especially in relationships which are already abusive, the potential for further violence may be significant.

Fifth, advocates of partner notification programs frequently link them philosophically and operationally to name reporting and nonanonymous testing, both of which raise additional fears for the security of HIV-related information. Philosophically, each strategy places more power in the hands of the state and less in the hands of the individual. Perhaps more iniportantly, nuany pubhic health officials also tie these programs together operationally. They see partner notification programs as both a justification for and a logical extension of nonanonymous testing and name reporting. ${ }^{285}$ Generally, these officials oppose anonymous testing because it prevents the testing agency from tracking down those who test HIV positive but fail to return for their test results. ${ }^{286}$ When those who test HIV positive fail to get their results, partner notification efforts are also stymied. Similarly, without a requirement that the names of HIV-positive persons be reported to the health department, the department has no way of initiating the partner notification process itself by directly contacting the HIV-positive person. Instead, health officials are placed in the passive role of waiting for the HIV-positive person to contact them. ${ }^{287}$ But the linkage of partner notification with nonanonymous testing and name reporting increases fears about insufficient privacy protections and potential confidentiahity breaches because both nonanonymous testing and name reporting represent government intrusion into the most private aspects of people's lives. This intrusion poses a constant threat that the information gathered in government hands-that is, people's names and HIV status-will not be treated confidentially, and risks deterring people from the health care systen. ${ }^{288}$

284. Partner notification programs, of course, reach directly into the most intimate types of relationships. Although partners are never told the identity of the person naming them, partners in a primary relationship (e.g., marriage) may quickly assume that it was their primary partner. An HIVpositive woman whose partner is informed of possible exposure faces a risk of not only physical violence, but also loss of economic support for herself and/or her children.

This concern is likely to increase as more and more women are tested for HIV as part of prenatal and neonatal screcning programs. Additionally, no protocols exist to help counselors of female HIV patients assess the potential for domestie violence. Therefore, it is likely that notification will proceed without any serious assessment of the risk of violence. See Rothenberg \& North, supra note 55 (recognizing the dilemma posed by the "foreseeable" risk of violence against HIV positive women due to partner notification policies and a health professional's arguable legal duty to warn, and proposing a risk/benefit assessment to be used by professionals who encounter this dilemma).

285. See, e.g., Judson, supra note 278, at 63; James H. Lee et al., Voluntary Human Immunodeficiency Virus Testing, Recidivism, Partner Notifcation, and Sero-Prevalence in a Sexually Transmitted Disease Clinic: A Need for Mandatory Testing, I7 Sexually Transmitted Diseases 169, 169 (1990).

286. See, e.g., Judson, supra note 278 , at 64 ; Judson \& Vernon, supra note 43 , at 388.

287. See, e.g., American Medical Ass's, Digest of HIV/AIDS Policy 7 (I993) (calling for name reporting so that partner notification can be carried out by health departments).

288. See supra notes 62,74 and accompanying text. 


\section{Present Confidentiality Protections and Partner Notification}

Current California law does not present a barrier to intensified partner notification programs, as the HIV confidentiality statute permits partner notification. ${ }^{289}$ A physician possessing a patient's HIV-positive test results may, at his or her discretion, disclose that information to "a person reasonably believed to be the spouse, or to a person reasonably believed to be a sexual partner or a person with whom the patient has shared the use of hypodermic needles."290 The statute explicitly exempts physicians from any duty to disclose, making disclosure entirely discretionary. ${ }^{291}$ Before notifying partners, the physician must first attempt to obtain the patient's consent. $^{292}$ In the course of disclosure, the physician may not reveal "any identifying information about the individual believed to be infected."293 However, in some circumstances, such as notification of a spouse or exclusive sexual or needle-sharing partner, the disclosure will result in constructive identification of the individual who has tested HIV positive.

The statute also permits the county health department to undertake systematic partner notification. As with notification by physicians, the provisions allow the county health officer to alert those reasonably believed to have been sexual or needle-sharing partners of persons known to be HIV positive. ${ }^{294}$ Importantly, the statute also requires that the records regarding the HIV-positive person and his or her contacts must be expunged upon completion of any contact tracing efforts. ${ }^{295}$ Although this provision lessens the concern about state possession of registers of "possibly exposed persons," the state might easily justify the maintenance of such records for extended periods of time. For instance, if the state believes that not all partners or contacts have been identified or located, it might maintain its records indefinitely.

Although the HIV confidentiality statute expressly allows partner notification, a person involved in such a program could have recourse under the statute for a breach of confidentiality. If, for example, a private physician were to attempt to notify not only the index patient's partners, but also the partners of those notified, the physician would almost certainly be exceeding the bounds of the statute. Alternatively, if the physician were to disclose the name of the index patient in the course of notification, or fail to

289. Cal. Health \& Safety Code $\S 199.25$ (West 1990).

290. Id. § 199.25(a).

291. Id. \$ 199.25(c).

292. Id. $\$ 199.25(\mathrm{~b})$. California's basic process for partner notification-patient notification as the preferred method with provider notification as a back-up option-is typical for states. See Nicole Tumer, Partner Notification Programs: Redefining Contact Tracing?, INTERGoverNMENTAL AIDS REP. (AIDS Pol'y Ctr., Washington, D.C.), Sept. 1992, at 12 (providing an overview of partner notification programs in different states).

293. Cal. Health \& Safety Code $\S 199.25$ (a) (West 1990).

294. Id. § 199.25(d).

295. Id. 
seek the index patient's consent, the physician would again be acting contrary to the mandate of the statute. The person whose confidentiality was breached might then have recourse under the HIV confidentiality statute. In addition, if the information disclosed were "individually identifiable," the person could pursue a claim under the Confidentiality of Medical Information Act.

Finally, privacy doctrines will provide little protection for HIV-related information in the context of partner notification programs. The public health foundation of partner notification programs likely satisfies the constitutional requirement that an initiative be undertaken for a legitimate public health purpose. Provided that the program's design and implementation are geared toward achieving that purpose, the courts would almost certainly find the means used sufficiently related to the public health purpose to pass constitutional muster. Similarly, so long as a partner notification program operates pursuant to and in accordance with valid state law or regulation, it is also unlikely that common law privacy protections would come into play.

\section{Partner Notification and Public Health}

Expanded partner notification programs can pose real threats to confidentiality of HIV-related information. Yet unlike the case of mandatory name reporting, some empirical evidence suggests that, under certain circumstances, partner notification programs can serve a valuable public health function. However, the evidence of the efficacy of partner notification is mixed at best. This ambiguity exists, at least in part, because any line drawn between "success" and "failure" for partner notification programs will inevitably be arbitrary, given the difficulty of proving a negative proposition like the number of HIV infections prevented by notification of an individual. Regardless of where any such line is drawn, proof of partner notification's effectiveness against the spread of HIV is sufficiently shaky to require careful balancing against the clear dangers it poses to confidentiality.

\section{a. Weighing the Evidence}

Studies conducted on the efficacy of partner notification programs lead to three general conclusions supportive of expanding these efforts. First, a significant number of HIV-positive people do not notify their own partners. ${ }^{296}$ Therefore, if one seeks to further the goal of ensuring that poten-

296. See, e.g., Suzanne E. Landis et al., Results of a Randomized Trial of Partner Notification in Cases of HIV Infection in North Carolina, 326 NEw ENG. J. MED. 101 (1992) (finding that, when patients had the initial responsibility for notifying their partners, they notified only $7 \%$ of partners on their own); Marks et al., supra note 72, at 100-01 (reviewing several studies which demonstrate low anticipated and actual reporting rates); Gary Marks et al., Self-Disclosure of HIV Infection to Sexual Partners, 81 AM. J. PUB. HEALTH 1321 (1991) (finding very low rates of partner notification among a sample of 138 gay and bisexual men, but cautioning that the restricted nature of the study "precludes any wide generalization of the results"). 
tially HIV-positive persons become aware of their status, methods other than notification by HIV-positive persons themselves should be explored. Second, some previously untested persons at sigmificant risk of infection can be identified and tested for HIV as a result of partner notification programs. ${ }^{297}$ Of course, some of those notified decline to be tested and others already know their antibody status. ${ }^{298}$ Importantly, though, some of those who may get tested for the first time previously did not believe themselves to be at risk for exposure. Perhaps most significantly, some women who mistakenly believe their partners to be monogamous and HIV-negative may have no other means of learning that they are at grave risk of infection. ${ }^{299}$

Third, substantial numbers of individuals who get tested as a result of partner notification programs are HIV positive. ${ }^{300}$ These data support the argument that partner notification programs effectively focus prevention efforts on especially high-risk people, that is, those known to have been exposed-if not necessarily infected-by an identified HIV-positive person.

However, the evidence about the overall efficacy of HIV partner notification programs is inconclusive. First, the absolute numbers of partners identified, notified, and tested in many studies are low..$^{301}$ Consequently, it is difficult to assess the overall potential impact of widespread partner notification. Second, several studies have identified crucial operational issues that almost certainly diminish the impact partner notification could have on containing the spread of HIV. Perhaps chief among these issues is the simple fact that many of those receiving positive HIV test results decline to

297. See, e.g., V. Arendt et al., Experience of Partner Notification Among HIV Infected Heterosexuals in Brussels, in ABSTRACTS, FIFTH INTERNATIONAL ConferenCE on AIDS 67 (1989) (reporting testing of 92 heterosexual partners by end of two-year partner notification program); Judson, supra note 278 , at 63,70 (discussing results of Colorado partner notification program in which 452 previously untested persons were tested after being notified of possible exposure); Kristina Ramstedt et al., Contact Tracing for Human Immunodeficiency Virus (HIV) Infection, 17 SEXUAlly TRANSMITTED DisEASEs 37, 40 (1990) (finding that 21 out of 38 partners who tested positive after notification were previously unaware of their serostatus); Toomey \& Cates, supra note 276, at S59 to S60 (reviewing numerous studies and numbers of partners contacted through them).

298. See, e.g., Landis et al., supra note 296 , at 103 (indicating that of 78 partners successfully notified by the health department, 42 declined to be tested).

299. See, e.g., Partner Notification for Preventing HIV Infection, supra note 61, at 401 . In addition, many women who may actually suspect their partners' high-risk behavior face difficulty negotiating condom use during sex. See Kathryn ABastos \& Carola Marte, Women-The Missing Persons in the AIDS Epidemic, HeALTH/PAC BuLl., Winter 1989, at 6, 11-12; Rothenberg \& North, supra note 55 .

300. One survey of studies found that HIV positivity rates annong persons tested as a result of notification of possible exposure ranged from $7 \%$ to $36 \%$ of those tested. Toomey \& Cates, supra note 276, at S59. Studies by the CDC in Virginia, Colorado, South Carolina, and Idaho found HrV-positivity rates of $14 \%, 15 \%, 18 \%$, and $39 \%$, respectively. Partner Notification for Preventing HN Infection, supra note 61 , at $394-96$.

301. See, e.g., Crystal et al., supra note 64, at 289 (160 partners notified and counseled after one year of program operation); Landis et al., supra note 296, at 101 (78 partners notified of possible exposure during year and a half study). 
participate in the programs..$^{302}$ Those who do participate may also be those most likely to view partner notification as important; correspondingly, those not participating may be those least likely to notify partners themselves. Moreover, among those who agree to participate, many name very few partners. ${ }^{303}$

Third, and perhaps even more importantly, partner notification programs appear likely to have the least impact among urban gay male and injection drug using populations, two of the population groups most heavily represented in ADS statistics. Among urban gay and bisexual men, the need for partner notification programs is limited by the fact that most are already aware that the prevalence of HIV infection among their potential partners is high; thus, the "warning value" of partner notification diminishes. ${ }^{304}$ The high level of infection, combined with the relatively high number of sexual contacts that some urban gay men report, dramatically increase both the logistical complications and the costs of partner notification. ${ }^{305}$ Moreover, fears of the possible consequences of cooperation with the health care system tend to run higb among gay and bisexual men, and consequently gay men tend to report fewer partners and cooperate less fully with partner notification programs than other groups. ${ }^{306}$

Injection drug users represent another population among whom partner notification programs have proven problematic. Because anonymous needle-sharing activity is fairly common, many who are HIV positive simply do not know the identity of their partners. ${ }^{307}$ IDUs also may have many partners, which raises the costs and difficulties of partner notification. ${ }^{308}$ In addition, as is true in many states with gay/bisexual men and sodomy, ${ }^{309}$ injection drug use is a crime, and therefore willingness to cooperate in partner notification programs is probably more limited among IDUs than among the general population.

302. See, e.g., Crystal et al., supra note 64 , at 284 (reporting that only $10 \%$ of those testing positive in New Jersey accepted assistance in partner notification); Landis et al., supra note 296, at 101 (reporting that nearly $50 \%$ of those tested did not return for results and of those who returncd, $50 \%$ declined to participate in notification program); Suzanne Laussucq et al., Syphilis Contact Tracing in a New York City STD Clinic: Implications for HIV Partner Notification, in Abstracts, FifTH INTERNATIONAL CONFERENCE ON AIDS 133 (1989) (suggesting that partner anonymity, lack of locating information, and concerns for confidentiality may result in few identifications of partners among HIVinfected patients).

303. See infra note 306.

304. See, e.g., George W. Rutherford et al., Partner Notification and the Control of Human Immunodeficiency Virus Infection, 18 Sexually Transmitted Diseases 107, 107 (1991) (discussing reasons for de-emphasizing partner notification within San Francisco's gay male community).

305. See, e.g., Judson, supra note 278 , at 63.

306. See Laussucq et al., supra note 302 , at 133 ; Spencer et al., supra note 74 , at 26 (reporting that gay men identified fewer partners than heterosexual men and referred a lower proportion of partners).

307. See Gostin, supra note 49 , at 153.

308. See Toomey \& Cates, supra note 276 , at $\$ 59$.

309. See supra note 47. 
Finally, an evaluation of the effectiveness of partner notification and contact tracing programs must take into account any possible deterrent effect that the programs' very operation might have. The case for partner notification would be severely undercut if the programs were to create a disincentive for people to access the health care system. For example, a woinan who believes that receiving a positive HIV test result could lead to her partner being notified may decide not to get tested because she fears a violent response from the partner. Others might be deterred from testing out of concern that confidentiality may not be inaintained, or because of fears that their names will end up on a list that may be used to harm them.

The one way in which partner notification and contact tracing programs appear to promise the greatest impact is when efforts are focused on specific, targeted populations. Some studies strongly suggest that partner notification programs will be most effective within certain relatively welldefined population groups. ${ }^{310}$ For example, one study focused on a relatively discreet population of gay and bisexual men in rural South Carolina. Beginming with a single HIV-positive gay man, the prograin identified 90 partners (either of the original "index" patient or other HIV-positive men identified through the program), of whom 12 were seropositive. ${ }^{311}$ The study's authors concluded that the project's success in finding seropositive persons was due in significant part to the fact that the targeted populationrural gay and bisexual men-was limited in size. ${ }^{312}$

Heterosexual women at risk of HIV infection may be the most prominent and important example of the potential effectiveness of targeted HIV partner notification programs. San Francisco in the late 1980s decided not to focus partner notification efforts on the city's large gay male population but instead on the much smaller population of at-risk women of childbearing age. ${ }^{313}$ The city's health department determined that partner notification promised the greatest impact by targeting a group, women of childbearing age, that was relatively unlikely to consider itself at risk for infection. The study concluded that partner notification, though costly, was an effective means of targeting case-finding efforts for women of childbearing age.

310. An analogy to these targeted HIV partner notification efforts can be seen in the use of partner notification programs to help stem the spread of localized outbreaks of communicable diseases. See Partner Notification for Preventing HIV Infection, supra note 61, at 393, 396, 401 (listing studies supporting use of partner notification to control local outbreaks of STDs); Toomey \& Cates, supra note 276 , at S57 (same).

311. Randolph F. Wykoff et al., Contact Tracing to Identify Human Immunodeficiency Virus Infection in a Rural Community, 259 JAMA 3563 (1988).

312. Although the study does not address the issue, it is possible that because the tracing effort occurred in a rural area, the program might have raised confidentiality fears because areas with low populations tend to have more tightly knit communities than urban areas. Whether the tracing program had any deterrent effect to later testing by gay and bisexual men, however, is unknown.

313. Rutherford et al., supra note 304 , at $107,109$. 
Two factors appear to make partner notification potentially useful and appropriate for notifying women of possible exposure. First, women are generally less likely to believe themselves at risk of infection, especially if they are married or in a relationship with a regular partner. ${ }^{314}$ Second, they constitute a relatively small pool of partners to be notified, compared, for example, to gay and bisexual men. Therefore, such a population allows resources to be targeted with greater precision and might not overtax already burdened health department resources.

\section{b. Balancing Confidentiality Concerns and Public Health}

The evidence supporting the public health efficacy of partner notification and contact tracing programs fails to make such a compelling case that the confidentiality concerns inherent in these programs can be laid aside in the interests of achieving a greater public benefit. While the empirical evidence presents a highly ambiguous picture, the confidentiality threats are real, especially if these programs continue to be linked to other aggressive and intrusive public health measures like name reporting and nonanonymous testing. Moreover, it is far from clear that expending scarce public lealth dollars for intensified partner notification programs will lead to more identification of HIV-positive individuals and prevention of transmission of the disease than putting those same resources into carefully targeted and tailored education campaigns. ${ }^{315}$

Nevertheless, partner notification programs do appear to have potentially significant public health benefits in at least limited circunistances. Eliminating these efforts would likely mean that some who might be alerted to their risk of infection, or brought into early treatment, would be missed. Heterosexual women with bisexual male and/or injection drug-using partners may be the population most likely to benefit from partner notification. Further policy development of partner notification and contact tracing programs, therefore, should take into account that these programs may well be effective in certain limited circumstances.

However, the threats to confidentiality inherent in contact tracing and partner notification must be addressed. To the extent that these programs are implemented, it is essential that partner notification be decoupled from name reporting and nonanonymous testing. There is no necessary connection between these programs; partner notification and contact tracing can and should be carried out in conjunction with a system of anonymous test-

314. See Confidentiality Said to Clash With Interests of Mothers, AIDS POL'Y \& L. (Buraff Publications, Washington, D.C.), Mar. 22, 1989, at 10.

315. See George W. Rutherford \& Jean M. Woo, Contact Tracing to Control the Spread of HIV, 260 JAMA 3275 (1988) (reply letter) (suggesting that where education efforts have been inadequate, health funds would be better expended in education efforts than partner notification). 
ing and without name reporting. ${ }^{316}$ In addition, confidential treatment of all individually identifiable HIV-related information must be the central concern of all such programs.

\section{Impact of the Redefinition of AIDS on Confidentiality}

As discussed above, no federal statute specifically incorporates confidentiality protection for CD4 information. Unless the CDC changes course, there will be no specific federal requirements for the confidential treatment of CD4 information, which is now widely used to define an AIDS condition. ${ }^{317}$

Nor does CD4 information receive any particular protection in California. The HIV confidentiality statute covers only information arising from an "HIV test," the definition of which does not include CD4 blood counts. ${ }^{318}$ In 1993, state Senator Tom Hayden introduced a bill in the state legislature to amend Health and Safety Code section 26 to incorporate within the definition of "HIV test" any "laboratory test to measure CD4 lymphocyte counts when the test is used to establish the likelihood of HIV infection, or otherwise in connection with HIV disease." 319 Although passed by both the state Senate and Assembly, the bill was vetoed by the governor. ${ }^{320}$ Nevertheless, the approach used in Senator Hayden's bill represents one clear way to ensure that CD4 information receives the confidentiality protection it needs.

Unlike the current HIV confidentiality law, the Confidentiality of Medical Information Act should cover CD4 information that is individually identifiable (by name or other means). ${ }^{321}$ CD4 information is medical information, and the CMIA is designed to be general in scope and incorporate all medical-related information. However, the question remains whether such protection is adequate to protect confidentiality. The CMIA does provide a clear potential cause of action for an individual whose CD4 count is disclosed outside the statutory exceptious. Furthermore, a person other than a "health care provider" under the statute's definition is probably less likely to have access to CD4 information, since it is technical medical information, of greatest use for chinical diagnosis, treatment, and care. ${ }^{322}$

316. See, e.g., Evelyn M. Blankenship et al., HIV Partner Notification Within an Anonymous Testing System, in ABstracts, Fifth INTERNATIONAL CONFERENCE ON AIDS 743 (1989) (describing the feasibility of a partner notification program run out of an anonymous testing program).

317. See supra notes $117-20$ and accompanying text.

318. See supra notes $125-26$ and accompanying text.

319. S.B. 670, Cal. Leg., 1993 Sess. The bill was strongly opposed by California insurers. Mike McKee, Insurers Take Aim at AIDS Privacy Measure, ReCORDER, May 7, 1993, at 1.

320. See Greg Lucas, Wilson Vetoes Needle-Exchange Program Again, S.F. ChroN., Oct. 9, 1993, at A17.

321. See supra notes $157-68$ and accompanying text.

322. It is likely, however, that insurers (in particular) would have great interest in such information about potential insureds. See McKee, supra note 319. Therefore, concerns persist about possible access to the information by persons outside the medical context. 
Given the volatility of AIDS as a disease, making use of the general confidentiality statute is arguably the best long term strategy. It is possible that AIDS may be further redefined in the future, or that a new test or new information will come into use. Rather than fine-tune statutes and policies with each new development, it may make the most sense to utilize the already existing general medical confidentiality statute.

However, there are several reasons why leaning on the CMIA may not be the best approach to guarantee the confidentiality of CD4-related information. First, specific protections would remove any question in the minds of those handling CD4-related information that they must maintain strict confidentiality when dealing with such information. Second, specific protections would help to assure persons seeking tests that their interest in confidentiality will be safeguarded. This may encourage people to seek what care and treatment is available in the health care system. Third, at a more symbolic level, specific protections would demonstrate the state's recognition of the critical public policy concerns behind confidentiality, giving clear notice to the public and to health care providers that the state values individual privacy rights with respect to HIV-related information. ${ }^{323}$

Fourth, specific protections would make the HIV-specific confidentiality law more complete. CD4 information is substantially the same as HIV information, and disclosure of one would have the same harmful effects as disclosure of the other. Therefore, it makes sense that breaches of confidentiality of $\mathrm{CD} 4$ information should be subject to the same penalties as breaches of confidentiality of HIV information. Under the CMIA, penalties for violation are less severe than those available under the HIV confidentiality statute, which include the possibility of jail time in addition to liability for damages and civil fines.

Finally, the purpose of confidentiality protections is not only to provide redress to aggrieved parties but to deter breaches before they occur. The more clear and specific the protection, the more effective the deterrence. Although amendment of the HIV specific statute to protect the confidentiality of CD4 information cannot deter all potential breaches, it may strengthen both the actual and symbolic deterrent power of that statute.

Disclosure of CD4 information might also give rise to an action under constitutional or common law doctrines. Under California constitutional privacy doctrine, such disclosure could constitute the wrongful use of infor-

323. It would be fair to ask who would in fact recognize this as state policy. To have some effect on both health care consumers and providers, the state must attempt to make its posture known. The state could accomplish this task by a variety of means. For example, it could send a letter to all medical care providers outlining state policy on confidentiality as expressed in the Health \& Safety Code sections on HIV-related information. The opportunity for such a mailing as a gesture of public policy would be especially ripe if the statute were amended to include CD4 information. As to consumers, the state could publicize its policy by selectively broadcasting it to the communities most likely to harbor concerns about confidentiality, e.g., through the gay press. 
mation properly obtained. ${ }^{324}$ As a privacy tort, disclosure of CD4 information could amount to a public disclosure of private facts. However, the same limitations of these remedies which apply to HIV confidentiality apply as well to CD4 confidentiality. Courts are likely to give considerable weight to the state's interest in public health and in proinoting CD4 and HIV testing, effectively barring most constitutional privacy claims concerning the use and disclosure of information from such tests. In addition, since testing is becoming more laboratory-based, rather than physician controlled, the duty of confidentiality integral to common law theories is likely to be less strong, and therefore the availability of a remedy less certain. Perhaps most importantly, constitutional and common law protections inay offer more possibilities for remedy than for deterrence or prevention. Their protections are sweeping and general rather than sharply focused and easily understood by those handling sensitive information. Therefore, they are likely to be of less value in communicating clearly to anyone handling HIVrelated information, including CD4 information, that such information must be treated in strict confidence.

\section{$\mathrm{V}$}

\section{Toward Strengthentng Confidentiality Protections}

\section{A. Protecting HIV-Related Information}

Given that the trend toward greater emphasis on aggressive public health measures sucli as mandatory name reporting, contact tracing, and partner notification appears likely to continue, federal and state governments must take steps to preserve and strengthen the confidentiality of HIVrelated information. The steps proposed below serve a dual purpose. First, existing confidentiality protections will be buttressed to guard against breaches of confidentiality in the various contexts in which they might arise. Second, these measures will send a strong message to the communities at greatest risk of HIV infection that their interests and privacy will be protected by both the national and state public health systems. In turn, this assurance will encourage people to seek HIV testing, thereby bringing them into contact with the public health surveillance and health care systems. Accordingly, the emphasis in these recommendations rests on ensuring that breaches of confidentiality do not occur.

\section{Federal Policy}

HIV confidentiality policy should be chiefiy a national policy. Although the need for confidentiality protection is the same throughout the country, some states are less likely to enact and enforce strong protections without federal direction or incentives. Moreover, significant variation among states in the levels of protection provided can lead individuals who

324. See supra note 210 and accompanying text. 
fear loss of confidentiality in their own state to cross state lines for testing and medical care. This outcome is neither healthy for the people compelled to travel long distances nor fair to those states with stronger confidentiality laws, as they may have to cover the costs of testing, counseling, and perhaps treating people from neighboring states. ${ }^{325}$

The first critical step toward strengtheming confidentiality protections at the federal level is statutory. Congress must enact a comprehensive law that safeguards the confidentiality of all medical information, including HIV-related information. The lack of a federal statute protecting medical information is a gaping hole in federal privacy protection that must be addressed as quickly as possible. The specific content of a national medical confidentiality law lies well beyond the scope of this Comment. However, its guiding principle should be that all medically related information is confidential and can be released only when such release is either necessary for the patient's own care or essential for achievement of a clearly defined, legitimate public health purpose.

The remainder of these recommendations require action by the federal Centers for Disease Control and Prevention. The CDC functions as the most important federal agency in setting confidentiality-related policy in the medical context. Not only has the CDC already established a role in shaping national and state confidentiality policies, but it also has a potent incentive mechanism at its disposal: the power to attach conditions to receipt of federal prevention grant funds. The Sections below which recommend $\mathrm{CDC}$ policy changes therefore advocate that the $\mathrm{CDC}$ make implementation of these recommendations by individual states a condition of receiving federal AIDS funds channeled through the CDC.

\section{a. Establish a Confidentiality "Floor" for HIV-Related Information}

Federal measures should include a comprehensive set of guidelines and recommendations to serve as a "confidentiality floor" for the states. If a state fails to put into place and enforce at least that level of protection, it would face a loss of federal funds. The CDC already requires that states protect confidentiality as a prerequisite to federal funding. ${ }^{326}$ Setting out minimum elements of confidentiality safeguards would be the simplest way to ensure an acceptable level of confidentiality protections in all parts of the country.

\section{b. Maintain and Enhance Anonymous Testing Options}

Providing opportunities for individuals to take AIDS-related medical tests under conditions of complete anonymity is a prerequisite to bringing many people-especially those in heavily affected populations-into the

325. See Name Reporting Still Stings, supra note 89, at 17.

326. See 1993 Revised Classification System, supra note 101, at 9. 
health care system. ${ }^{327}$ The CDC should encourage states to maintain, or, in states without anonymous HIV testing facilities, to create sites where individuals can receive anonymous HIV testing. The most effective way to encourage this would be for the CDC to provide funding for sites at which people could obtain both HIV and CD4 testing on an anonymous basis. Some individuals, often out of concern for confidentiality of HIV test results, choose to monitor their health through CD4 testing rather than HIV testing, particularly in states with mandatory HIV reporting and no anonymous testing options. Making anonyntous CD4 testing opportunities available will provide another route of access to the health system and encourage a slice of the population that has steered away from the system to enter it. This would meet the bottom line public health imperative that people who believe that they may have been exposed to HIV have ready access to testing and, if necessary, treatment.

\section{c. Prohibit Name Reporting of HIV-Positive Persons}

Ideally, the federal government should discourage name reporting of HIV-positive persons to state or federal agencies, or any similar programs that would make it possible to link names and serostatus. The state's only valid interest in HIV infection reporting lies in the surveillance data it contains: for example, what population groups are affected, what trends can be traced in the epidemic, and what numbers of persons have HIV infection and possibly AIDS. The state does not need names for such purposes. This information is available through implementation of a coded identifier system, without names or individually identifiable information going to state agencies. ${ }^{328}$ Several states have begun to experiment with such "unique identifier" systems, use of which addresses public health officials' concerns about avoiding reporting duplication and ensures that the state does not have the type of HIV registry that could easily be used for nonsurveillance-even punitive--purposes. Moreover, nonname systems that do not require mandatory name reporting will serve to reassure people that the state not only will not but also cannot misuse name-linked HIV-related information.

\section{d. Ban Nonsurveillance Uses of Surveillance Data}

The CDC should discourage state policies that allow the use of surveillance data for nonsurveillance purposes, such as the types of disclosures permitted by the Illinois health care worker/patient notification law. ${ }^{329}$ This federal policy should clearly encompass not only the health care worker and patient focus of the Illinois statute, but also any other state uses of surveil-

327. See supra notes 62,74 and accompanying text.

328. See Cooper \& Di Donato, supra note 281, at 6.

329. Ill. Comp. Stat. ANN. ch. 410, \& 325/5.5 (Smith-Hurd 1993); see supra notes $94-97$ and accompanying text. 
lance information for nonsurveillance purposes. The CDC can effectively prevent such laws from being enacted by stipulating that the misuse of state HIV registries will result in a loss of federal funds to the violating state. Likewise, the same prohibitions should apply to registries of CD4-related information and registries of diagnosed AIDS cases.

Given the volatihty of AIDS as a public policy and public health issue, and the proven tendency of the general population to deinand repressive responses to minute dangers of HIV transmission, ${ }^{330}$ there may ultinately be no way to guarantee that confidentiality-threatering measures will not be enacted at either the national or the state level. But leaving the confidentiality area vulnerable to the pressures of AIDS politics in fifty different states amounts to an invitation for such measures.

\section{e. Issue Comprehensive Guidance for Contact Tracing and Partner Notification Programs}

The empirical evidence does not support turning contact tracing and partner notification into mainstays of HIV prevention efforts. ${ }^{331}$ Any emphasis placed on contact tracing and partner notification inust mot coine at the expense of targeted, appropriate, and clear prevention education efforts. Furthermore, any additional expenditures made on contact tracing and partner notification should be limited to efforts targeted at specific populations in which the programs have been demonstrated to be effective.

In light of the growing use of such programs, however, the federal government should issue clear guidehnes to undergird state and local contact tracing and partner notification programs. At a minimum, prograns should have to adhere to these guidelines to qualify for federal funds.

Although the specific provisions of such guidelines exceed the scope of this Comment, they should reflect several key principles. The guidelines should mandate that programs inaintain anonymity and encourage voluntary participation and cooperation of HIV-positive patients. In no case should cooperation in notification programs be made an explicit or implicit prerequisite to necessary care and services. Guidelines should strongly emphasize the desirability of programs in which patients notify their own partners, with public health departments available to provide back-up support upon the patient's request. Partner notification programs should also ensure that those individuals charged with notifying the partners identified do not have access to the name of the original patient who identified the partner. Finally, the guidelines should suggest ways to tailor partner notification programs to the particular population targeted. A program aimed, for example, at woinen with inale partners inust take into account the real pos-

330. See supra note 77 and accompanying text.

331. See supra notes 301-09 and accompanying text. 
sibility of domestic violence, and contain adequate training for counselors to assess the risk of violence upon notification.

\section{State-Level Policy}

In California, the state government should clarify the scope of coverage under the HIV confidentiality statute in Health and Safety Code section 199.20. Clarification is particularly necessary following the court of appeal's decision in Urbaniak. ${ }^{332}$ Because the decision in Urbaniak limits the utility of section 199.20 as a remedy for breaches of confidentiality, thereby discouraging potential plaintiffs from bringing claims in the first place, California's HIV protections are inadequate. The legislature should amend section 199.20 expressly to include disclosures of HIV-related information that is not necessarily derived directly from HIV blood tests. The statute should cover HIV-related information in any form, including the kind of oral disclosure that the court found permissible in Urbaniak.

States that lack HIV-specific confidentiality laws altogether should adopt them, both to ensure against breaches of confidentiality and to signal that confidentiality will be maintained. Such laws should include, at a minimum, the kinds of protection described above as comprising a "confidentiality fioor." 333

\section{B. Protecting CD4 Information}

Many of the broad confidentiality protections discussed above will improve the safeguarding of CD4-related information. For example, a national medical confidentiality statute would cover CD4 information. In addition, however, three specific steps are needed to provide still further protection for CD4 information.

\section{Enact State Statutory Protections}

California and other states should enact specific statutory protections to safeguard the confidentiality of CD4-related information about individuals. Such a change would broaden the net of existing HIV-specific statutes. In California, the HIV-specific confidentiality sections of the Health and Safety Code should be amended along the lines delineated in the legislation proposed in the 1993 session by Senator Hayden. ${ }^{334}$ In essence, the changes mandated by this legislation would have put CD4 information on the same footing as "HIV test" information by including within the covered information "CD4 lymphocyte counts when the test is used to establish the likelihood of HIV infection, or otherwise in connection with HIV disease." 335

332. Urbaniak v. Newton, 277 Cal. Rptr. 354 (Ct. App. 1991).

333. See supra text accompanying note 326.

334. See supra note 319 and accompanying text.

335. S.B. 670, Cal. Leg., 1993 Sess. 
In states such as California that already have HIV-specific confidentiality statutes, a straightforward amendment of these statutes to expressly include CD4 information will accomplish this change. Two approaches are possible. First, a state could specifically incorporate CD4-related information in the HIV confidentiality statute, following the example of the Hayden bill. Alternatively, statutes could be written more broadly to protect the confidentiality of information concerning "immune system suppression related to infection with the human immunodeficiency virus." This latter formulation would cover not only CD4 information but also any information that indicated infection with HIV. Legislatures in states without specific HIV confidentiality statutes should enact separate statutes providing for confidential treatment of CD4 information by all parties-including health care providers, the state, and individuals-and attach civil and/or criminal penalties for violation. ${ }^{336}$

\section{Bar Laboratory-Based Reporting of Individually Identifiable Test Results}

The CDC should explicitly discourage the direct reporting of individually identifiable HIV-antibody and CD4 test results from clinical laboratories to state agencies. If a lab reports positive HIV-antibody test results by name, this causes all of the problems associated with all HIV name reporting schemes, and should be discouraged by federal policy. State efforts to require laboratories to report CD4 test results by name raise additional concerns. With the change in the definition of AIDS, the reporting of a CD4 test result below 200 may be treated as a surrogate for an AIDS diagnosis, especially for those HIV-positive individuals whose names have been reported to the state under an HIV name reporting program. Laboratories should be permitted to disclose CD4 test results only to a patient's physician (or provider institution), so as to offer the protection given by the generally strong tradition of doctor-patient confidentiality and to ensure that actual diagnoses of AIDS will be made in a clinical context-rather than by a matching of registries. Moreover, such a requirement will reinforce the crucial perception that a patient and his or her physician (or provider institution) maintain control over HIV-related information. This is an essential assurance to those people who may otherwise be reluctant to come forward for HIV testing and treatment.

If federal policy does not directly discourage laboratory reporting of CD4 (and HIV) test results, at a minimum the CDC should require states to use such a reporting system only by a unique identifier, not by name. For example, a physician requesting a CD4 test on a blood sample would attach

336. Of course, if a state currently lacks an HIV confidentiality law, it might accomplish the public policy and civil liberties objectives discussed in this paper more fully by adopting a comprehensive statute covering both HIV-related information and CD4-related information. 
a pseudonym or unique numerical identifier to the sample sent to a lab. ${ }^{337}$ If the results showed a CD4 count below 200 , the lab would forward the test result and the identifier to the relevant state health agency. The agency could then contact the physician to find out if the individual has been or should be diagnosed with AIDS, in which case reporting by name to the state agency would almost mvariably be required. The confidentiality key to the system is that, outside of the physician and the patient, no entity or individual can link the information to any particular individual.

\section{Require Informed Consent for CD4 Testing}

The principle of informed consent for HIV-antibody testing is wellestabhished and incorporated into standard HIV testing procedures throughout the country. ${ }^{338}$ The same is not true of CD4 testing. Given the new significance of CD4 testing-especially its use as a surveillance tool and the fact that it can effectively lead to a diagnosis of AIDS-it is essential that patients be thoroughly informed not only about the medical and treatment ramifications of the test results, but also the potential reporting implications of the test. The procedure should be the same as that established for HIV testing: before a patient's blood can be tested for CD4 levels, the patient must give written consent to the test. However, because CD4 screening is also used as an ongoing diagnostic tool by providers, written consent need not be required after the first administration of CD4 testing at each institution at which an individual receives care.

\section{Effect of Strengthening Confidentiality Protections on Constitutional Remedies}

The primary purpose behind the nieasures recommended above is, of course, to buttress protections for HIV-related and CD4 information. In addition, however, these steps should have the indirect effect of bolstering confidentiality protection by informing judicial consideration of constitutional challenges to aggressive HIV-related public health measures. As discussed above, when courts consider constitutional challenges to public health policies or programs, they look to the legitimacy of the state interest, the injury to privacy, and the relationship between the state's interest and the particular means used to achieve it. If the federal and state governments reinforce confidentiality policies as recommended above, those changes may cause courts to review more closely whatever practice, incident, or program is challenged. By emphasizing the public health purpose in ironclad confidentiality protections, the recommended changes will provide the courts with strong reason to scrutinize carefully policies that threaten confidentiality. For example, if a state requires lab-based name-based reporting

337. Cooper \& Di Donato, supra note 281 , at 6.

338. See supra note 116. 
of HIV status or CD4 information despite federal policy discouraging such schemes, a court may well give less weight to the state's asserted interest in collecting the names and invalidate a program challenged as invasive of privacy.

\section{CoNCLUSION}

The strict confidentiality of HIV-related information is as critical to meeting the threats and challenges of the HIV epidemic now as it was a few years ago. The resurgence of aggressive public health measures potentially threatens the reality and the perception of confidentiality. Existing protections may be sufficient to deter most breaches of confidentiality, or at least provide those injured by such breaches the opportunity to pursue legal remedies. However, these existing protections are not adequate to safeguard confidentiality in light of the resurgence of aggressive public health measures. Consequently, federal and state governments need to reinforce protections for the confidentiality of HIV-related information to ensure both the preservation of civil liberties and the promotion of the public liealth. 